\title{
Middle to Late Devensian glaciation of north-east Scotland: implications for the north-eastern quadrant of the last British- Irish ice sheet.
}

\author{
Jon W.Merritt ${ }^{1 *}$, E Rodger Connell ${ }^{2}$ and Adrian M. Hall ${ }^{3}$ \\ ${ }^{1}$ British Geological Survey, The Lyell Centre, Research Avenue South, \\ Edinburgh, EH14 4AP, UK. \\ ${ }^{2}$ Department of Geography, Environment and Earth Sciences, University of \\ Hull, Hull, HU6 7RX, UK. \\ ${ }^{3}$ Department of Physical Geography, Stockholm University, 10691 Stockholm, \\ Sweden
}

\begin{abstract}
We present a review of over 175 years of research into the Middle to Late Devensian (Weichselian) glaciation of north-east Scotland based crucially on both its lithostratigraphic and geomorphic records. The location of the region, and surrounding seabed, makes this unusually detailed record significant for deciphering the former interactions and dynamics of Scottish and Scandinavian ice within the North Sea Basin (NSB), which continue to be controversial. A twelve-stage event stratigraphy is proposed based on a parsimonious interpretation of stratigraphic relationships, till lithology and regional clast fabrics, striae, subglacial bedforms, ice-marginal features and published geochronometry at critical sites. The record of regional glaciation supports converging evidence that the north-eastern quadrant of the last British and Irish Ice Sheet (BIIS) reached its maximum spatial extent in the late Middle- to early Late Devensian and later re-expanded following widespread internal glacial reorganisations, marine transgression and partial retreat from the central NSB. Retreat was interrupted by several glacial readvances of limited extent. Fieldcaptured data helps identify important events that are not clearly resolved from remote sensing alone, particularly regarding growth phases of the last glaciation.
\end{abstract}

KEYWORDS: British Irish Ice Sheet; North-east Scotland; Buchan; lithostratigraphy; Devensian; North Sea; till lithology; erratics.

${ }^{*}$ Correspondence: J.W.Merritt, Honorary Research Associate, as above. Email: jwm@bgs.ac.uk

\section{Introduction}

The Pleistocene stratigraphical record in the north-east of Scotland (Figure 1) includes glacigenic deposits and periglacial phenomena representing cold stages back at least to Marine Isotope Stage (MIS) 8, together with terrestrial 
sediments with a biological or pedological record of interstadial and interglacial climates (Merritt et al., 2003, Evans et al., 2005). This unique record derived from over 175 years of published research in the region is important in understanding the history of the northern sector of the last BIIS and its interaction with ice flowing into the central NSB from Scandinavia.

In this paper we review published evidence pertaining to the last, Middle to Late Devensian/Weichselian glaciation of north-east Scotland (Figure 2). We attempt to integrate the lithostratigraphical record (Merritt et al., 2003) with the subglacial bedforms mapped by Hughes et al. (2010) and ice-flow patterns (flowsets) interpreted from that record (Hughes et al., 2014). Of particular interest are the events that occurred during build-up phases of glaciation, which have left little geomorphological footprint and are least well resolved in current reconstructions of the north-east sector of the last BIIS (Bradwell et al., 2008; Scourse et al., 2009; Clark et al., 2012; Hughes et al., 2014, 2016). Recalculated published dates are taken from a database of geochronometric information for the British Isles (Hughes et al., 2011, 2016).

We offer a new event stratigraphy and conceptual glacial reconstructions based on a detailed, critical review of the literature. Sites mentioned in the text together with striae and a selection of geomorphological features identified from BGS mapping and the extensive literature are located on summary maps given in Merritt et al. (2003, maps 1-11), which is also available at http://earthwise.bgs.ac.uk/index.php/Cainozoic geology and landscape evol ution of north-east Scotland. Details of important Quaternary sites on which the stratigraphy is based are given in Table 2. A correlation chart is given in Table 3, which includes most named lithostratigraphical units. Details of the lithology, provenance and ice flow directions of key till units is given in Table 4. Compass directions have been shortened in the following text, eg. NE for north-east.

\section{Topography}

NE Scotland encompasses the eastern Grampian Highlands and the lowlands of Moray and Buchan, which rise south-westwards towards the mountains of the Cairngorms, Gaick and the Mounth, reaching over $1000 \mathrm{~m}$ above Ordnance Datum (OD) (Figure 3). The region is drained by two principal eastflowing rivers, the Dee and Don, which reach the North Sea at Aberdeen. The Deveron drains NE towards the Moray Firth at Banff and the Spey reaches the firth at Spey Bay. Two other major NE-trending rivers, the Findhorn and Nairn, reach the Moray Firth further to the west (Figure 4). The landscape of NE Scotland is characterised by ancient plateau surfaces eroded across a wide variety of rock types (Hall, 1991). The predominant surface is the rolling Buchan Plateau, lying between 60 and $150 \mathrm{~m}$ OD, which embraces Mormond Hill (234 m OD), an isolated inselberg formed of metaquartzite lying between Fraserburgh and Peterhead. The Buchan Plateau is overlooked on its southwestern margin by Bennachie (528 m OD), an iconic local granite mountain.

\section{The lithostratigraphy and bedrock geology of NE Scotland}


The traditional approach of establishing lithostatigraphical relationships and correlations has been used to help decipher the particularly complex sequence of events and glacial interactions that have occurred in NE Scotland (Merritt et al., 2003). The earlier informal 'series' (Sutherland, 1984; Hall and Connell, 1991) have been incorporated into a formal 'top-down' lithostratigraphical scheme that embraces all superficial deposits in Great Britain (McMillan et al., 2011; McMillan and Merritt, 2012). The series are replaced by subgroups, units of which have been assigned to two groups, the Caledonia Glacigenic Group, of MIS 2-5e age, and the Albion Glacigenic Group, representing older glaciations. The use of descriptive qualifiers, such as 'glacigenic', and other issues of protocol are discussed by McMillan and Merritt (2012). An overview of the lithostratigraphical framework for Quaternary deposits on the UK continental shelf is given by Stoker et al. (2011).

The 'blue-grey series' of Synge (1956), renamed as the Banffshire Coast and Caithness Glacigenic Subgroup (BCCGS) relates to the suite of deposits laid down by ice that flowed onshore from the Moray Firth (Figure 5). The 'red series' of Jamieson (1906) has been subdivided in order to separate deposits that were laid down by ice that flowed onshore from the North Sea Basin (Logie-Buchan Glacigenic Subgroup) (L-BGS) from those that were derived entirely from ice flowing north-eastwards along Strathmore (Mearns Glacigenic Subgroup) (MGS). The 'inland series' of Hall (1984) has become the East Grampian Glacigenic Subgroup (EGGS). Additionally, deposits laid down by ice that arrived by circuitous routes from the western Central Highlands are assigned to the Central Grampian Glacigenic Subgroup (CGGS), whereas ice that flowed from the NW Highlands via the Great Glen laid down the tills of the Inverness Glacigenic Subgroup (IGS). Each subgroup includes formations, members and beds (abbreviated to F, M and $\mathrm{B}$ respectively).

All modern Superficial Deposits editions of BGS 1:50k mapping covering the region may be downloaded from http://www.bgs.ac.uk/data/maps/home.ht. Details of type sections and metadata are given in McMillan et al. (2011). The correlation chart given in Table 3, includes some later Middle and Late Pleistocene non-glacial, terrestrial sediments, periglacial deposits and soils that provide important biostratigraphical and geochronometric evidence and stratigraphical markers. These units are included in the Britannia Catchments Group of McMillan et al. (2011). Detailed descriptions of many of the sites in the region that have provided important stratigraphical information over the years are given in the Geological Conservation Review for the Quaternary of Scotland (Gordon and Sutherland, 1993), now available online at http://.jncc.gov.uk. These site descriptions and additional ones are summarized in Merritt et al. (2003, appendix 1). Undoubtedly the longest record has been obtained from the Kirkhill and Leys sites, in eastern Buchan (Table 2) (Connell et al., 1982; Hall and Connell, 1991; Connell and Hall, 2000).

Bedrock has greatly influenced the lithology and provenance of glacigenic deposits in the region, providing valuable indicator erratics. It ranges in age 
from Late Precambrian to Lower Cretaceous (Trewin, 2002; Merritt et al., 2003, fig. 2). Resistant rock types such as granite and metaquartzite generally form positive topographical features, whereas gabbro and ultramafic rocks commonly form areas of negative relief. The south of the region includes the gently undulating Vale of Strathmore, underlain mainly by Old Red Sandstone (ORS) lithologies and associated Late Silurian-Devonian volcanic rocks. Although Strathmore is generally low-lying, conglomerates near the Highland Boundary Fault and the coast form higher ground. ORS lithologies also underlie the coastal lowlands between Elgin and Inverness.

Relatively soft Mesozoic and Cenozoic rocks crop out a short distance offshore beneath the Moray Firth and North Sea basins and are the source of many erratics, fossils and glacial rafts onshore. Jurassic rocks crop out only in the Moray Firth, which is of significance for mineralogical and palynological studies of the provenance of glacigenic sediments, both onshore and in the North Sea Basin. Chalk does not crop out on the mainland, but strong evidence of a former cover and post-Upper Cretaceous uplift is given by the presence of nodular flints at the base of the Buchan Gravels Formation, of Palaeocene to Eocene age (McMillan et al., 2011; Hall et al., 2015). These distinctive flint and quartzite gravels cap some of the highest ground in Buchan and demonstrate that topographic inversion occurred prior to the Pleistocene (Hall, 1987; Merritt et al., 2003; Rea and Gemmell et al., 2006)

\section{The terrestrial glacial record}

The landscape of NE Scotland has generally experienced relatively little cumulative glacial modification as it lay peripherally to the main ice-dispersion centres in the central and western Highlands of Scotland during successive glaciations (Clayton, 1974; Hall and Sugden, 1987; Hall, 1991). There is particularly significant preservation of deeply weathered regolith and residual, hill-top flint and quartzite gravel deposits in Buchan (Figure 1) (Hall, 1985, 1986, 1987), where long periods of non-erosive ice cover have allowed the preservation of an unusually detailed stratigraphical record (Merritt et al., 2000,2003 ) and where periglacial deposits and landforms are common (Fitzpatrick, 1987; Connell and Hall, 1987).

The coastal lowlands have been crossed at various times by ice flowing from the NW Highlands, eastern Grampian Highlands and onshore, both from the Moray Firth and North Sea basins. This has resulted in the deposition of interdigitating glacigenic units of varied provenance (Figure 5; Table 4). The eastern Grampian Highlands were mainly affected by ice that flowed outwards from, and retreated back towards centres of accumulation in the Cairngorms, Mounth and Gaick, typically depositing yellowish brown, quartzo-feldpathic diamicts with numerous boulders. The Banffshire coast was affected by ice that flowed out of the Moray Firth Basin (MFB) to lay down calcareous, finegrained, typically dark bluish grey, shelly diamicts containing abundant erratics and rafts of Mesozoic rock and cold-water Quaternary sediments entrained from the bed of the firth (Peacock and Merritt, 1997, 2000a). The eastern coast was influenced by ice, sourced in the western Grampian Highlands, which flowed towards the North Sea through Strathmore. This ice 
flowed onshore into Logie (Lower) Buchan, to the north of Aberdeen, where it disintegrated to form relatively 'fresh' hummocky topography formed by a distinctive suite of calcareous, vivid reddish brown sediments containing clasts of Permo-Triassic sandstone, dolomite, calcareous siltstone and reworked shells from the adjacent NSB in addition to material from the Old Red Sandstone (ORS) and associated Devonian volcanic rocks of Strathmore.

The terrestrial glacigenic sequence, striae, clast fabrics and distribution of indicator erratics show that the relative importance of ice dispersion centres changed during the last, and previous glaciations (Clapperton and Sugden, 1977; Sutherland, 1984; Sutherland and Gordon, 1993). For example, ice flowing from the Great Glen was forced eastwards across the coastal lowlands bordering the Moray Firth during an early phase of the last glaciation (Sissons, 1967; Fletcher et al., 1996) (Figure 4), possibly deflected by ice flowing south-eastwards from an ice divide stretching along the spine of the NW Highlands (Read, 1923; Bremner, 1934a, Bremner, 1943). Ice flowed from the Moray Firth across Buchan towards Aberdeen (Hall and Jarvis, 1995). The most commonly cited explanation for this onshore deflection is that Scandinavian ice had occupied the central NSB, impeding the more logical flow of Scottish ice north-eastwards out of the Moray Firth (Peach and Horne, 1893; Bremner, 1943; Synge, 1956: Sissons, 1967), but evidence for this has not been substantiated by recent research in Caithness and Orkney (Hall and Riding, 2016; Hall et al., 2016).

There has been a long-standing debate whether parts of Buchan remained ice-free throughout the last glaciation (Sutherland, 1984), or became so relatively early during retreat of peripheral parts of the last ice sheet, when ice-marginal lakes (Glacial Lake Ugie) were ponded behind coastal ice lobes inland of Peterhead (Hall and Connell, 1991) (Figure 6). There was probably a sequential south-westward 'un-zipping' down the North Sea coast of 'Strathmore' and 'East Grampian' ice during deglaciation (Simpson, 1955), possibly accompanied by a marine incursion up to about $30 \mathrm{~m}$ OD (Peacock, 1999). Minor readvances at Aberdeen, Dinnet and Aboyne are thought to have interrupted the general westward retreat of East Grampian ice (Jamieson, 1906; Bremner, 1931; Bremner, 1943; Synge, 1956; Sutherland and Gordon, 1993; Brown 1993, 1994; Evans et al., 2005). Important evidence for a minor, late-stage onshore readvance of Moray Firth ice occurs at St Fergus (Figure 6c), where raised marine deposits lying up to about $17 \mathrm{~m}$ OD have been deformed within a low ridge, probably a push moraine (Hall and Jarvis, 1989; Peacock, 1997). Extensive glaciofluvial and glaciolacustrine deposits were laid down along the southern margin of Moray Firth as terrestrial ice retreated inland from the coast whilst ice remained offshore (Read, 1923; Merritt et al., 2003) (Figure 6c). Evidence from glaciofluvial fandeltas and glacial drainage channels indicate that a large ice-marginal lake(s) (Glacial Lake Rothes) occupied the lower reaches of Strath Spey during a minor readvance of ice within the Moray Firth known as the Elgin Oscillation (Peacock et al., 1968). The ice front retreated westwards into the inner Moray Firth, where a push moraine at Ardersier provides sound evidence for a subsequent glacial readvance (Merritt et al, 1995). 


\section{Glacial reconstructions}

Early models for the glaciation of NE Scotland are reviewed by Merritt et al. (2003). Although there is broad agreement on the relative sequence of events, they differ mainly regarding whether the events relate to phases of the last glaciation (eg. Clapperton and Sugden, 1977) or successive glaciations separated by interglacial or interstadial periods (eg. Jamieson, 1906; Bremner, 1943; Synge, 1956). It was believed that the British and Scandinavian ice sheets had been confluent during the last glaciation (Geikie, 1894; Jamieson, 1906; Wright, 1914; Read, 1923; Bremner, 1943; Synge, 1956; Charlesworth, 1957; Sissons, 1967; Boulton et al., 1977), but exploration of the central NSB subsequently revealed thick sequences of glaciomarine material apparently containing few, if any units of Late Weichselian diamict of demonstrable subglacial origin. This supported ideas that the BIIS had been much more limited in size, both in extent and thickness (Sutherland, 1984; Boulton et al., 1985, 1991; Sutherland and Gordon, 1993). For example, in Sutherland's (1984) reconstruction of an independent BIIS, ice terminates at the eastern margin of the Wee Bankie, off the eastern Scottish coast (Figure 1), and, following Synge (1956) and Flinn (1967), parts of Caithness, Buchan and northern Lewis fall beyond its limits. These nonglaciated enclaves subsequently appeared in many published reconstructions of the north-eastern sector of the last BIIS (Bowen et al., 1986; Bowen, 1989; Nesje and Sejrup, 1988; Boulton et al., 1991; Ehlers and Wingfield, 1991; Lambeck, 1995; Bowen et al., 2002; Clark et al., 2004), despite the evidence for them having been seriously questioned (Peacock, 1997; Hall and Bent, 1990; Hall, 1997; Whittington et al., 1998; Whittington and Hall, 2002), or refuted (Hall et al., 2003; Phillips et al., 2008). Nunataks formerly identified in the NW Highlands and Outer Hebrides by Ballantyne et al. (1998) lent support for a thin, low-profile ice sheet, but reinterpretation of the trimline evidence now indicates that the ice exceeded $900 \mathrm{~m}$ and $600 \mathrm{~m}$ in altitude over these areas respectively and that Scotland was completely buried beneath ice during the last glaciation (Ballantyne, 2010).

Evidence now suggests that Scandinavian and Scottish ice did indeed coalesce within the NSB at least during an early stage in the last glaciation, during the local Last Glacial Maximum (LGM) (Figure 2), when the BIIS was thick (Sejrup et al., 1994, 2009; Chiverrell and Thomas, 2010). This 'Atlantic Shelf Glaciation' at c. 32-25k cal a BP (Sejrup et al., 2003, 2005), or 32-27k cal a BP (Sejrup, 2015), was followed by the growth of more restricted ice sheets after c. 22k cal a BP. However, doubts surround the published geochronometry (Clark, et al., 2004) and it is difficult to explain why early deglaciation of the central NSB occurred during a period including the global LGM when other sectors of the BIIS were expanding (Hughes et al., 2016; Sejrup et al., 2016). It is generally agreed that the northern sector of the last BIIS built up towards the end of MIS 3, after c. 32k a BP, when ice extended to the continental shelf margin (Stoker and Holmes, 1991; Whittington and Hall, 2002; Wilson et al., 2002; Bradwell et al., 2008; Jacobi et al., 2009; Chiverrell and Thomas, 2010; Gibbard and Clark, 2011; Graham et al., 2011; 
Clark et al., 2012; Everest et al., 2013; Hughes et al., 2014, 2016; Hiemstra et al., 2015; Bradwell and Stoker, 2015a). It is unlikely that ice-free areas existed anywhere in northern Scotland during the global LGM, when the BIIS was thick (Ballantyne, 2010; Fabel et al., 2012) (Figure 2). Major readjustments occurred during later stages (Hughes et al., 2014) when ice streams became established in the Moray Firth (Merritt et al., 1995), the Minch (Bradwell and Stoker, 2015a) and the Firth of Tay (Golledge and Stoker, 2006), possibly as a result of switches in glacial behavoir.

\section{The subglacial bedform record}

Hughes et al. (2010) published a bedform map of Britain based on systematic remote interpretation from a high-resolution digital surface model (Next-Map Britain DSM; $5 \mathrm{~m}$ horizontal resolution). This landform record was interpreted primarily in terms of ice-flow vectors (flowsets) (Greenwood and Clark, 2009a) augmented with data on glacial erratic transport paths gleaned mainly from the older literature and contained within the BRITICE database (Clark et al., 2004) (Figure 3 and 4). Isochronous flowsets, representing a single flow event, were distinguished from time-transgressive (TT) imprints produced by smudging of two or more flow events (Figure 7). Flowsets in NE Scotland were organised into a relative age stack following examination of superimposition relationships of the constituent bedforms (Table 1). The flowsets were subdivided into those that disregard topography and those that are topographically-constrained. The former provide a glimpse of ice-sheet geometry during maximum extent, whereas most others formed during retreat phases. The TT flowsets are divided into those reflecting generally thinning ice and those specifically associated with retreating ice lobes. Clearly a flow event can create a landform from sediments that formed in a much older event and palimpsest features (Kleman, 1994) are likely to have been preserved in central Buchan where the stratigraphical record is longest and cold-based ice was predominant (Connell and Hall, 1987).

\section{Glacial retreat stages}

The pattern of glacial retreat across NE Scotland (Figure 8) has been established by Clark et al. (2012) as part of a countrywide analysis of moraines, eskers, glacial drainage channels and drumlins mapped by systematic visual interpretation of Digital Elevation Models (DEMs) and satellite images, the wider literature (Evans et al., 2005) and compilation of published dates (Hughes et al., 2011). The retreat pattern determined by these authors is generally accepted here, but there are exceptions. Notably, their onshore limit for ice that invaded Logie-Buchan from the east or SE has been modified and replaced by the western boundary of the lithostratigraphical subgroup of that name (Figure 5). This sharp boundary has been mapped out on the ground (Merritt et al., 2003, fig. 50) and the authors find no evidence that the ice encroached farther inland. Borehole information (McMillan and Aitken, 1981) shows that the Logie-Buchan ice reached northwards to beyond Peterhead (Figure 5), but any moraine features there have been obliterated by a subsequent expansion of Moray Firth ice. 
The retreat pattern presented by Clark et al. (2012, fig. 12) has also been modified along the eastern coast, where they infer that ice retreated inland from the Wee Bankie (Figure 1), a terminal moraine according to Sutherland (1984). However, there are no diagnostic features typical of an ice-marginal moraine, morainal bank or accretionary wedge, instead mainly NE-directed channels cut into red till (Figure 8). The channels were probably eroded beneath a lateral shear margin between Scottish ice and ice occupying the central NSB (Golledge and Stoker, 2006).

The complex retreat limits formed by moraine ridges south of Bennachie (Blairdaff Moraine Formation of Merritt et al., 2003) and around Durn Hill may be linked. A significant change in the character of the landscape occurs at about these limits, as noted by earlier workers. For example, periglacial phenomena, specifically ice-wedge pseudomorphs and surficial sheets of gelifractate and gelifluctate are widespread to the north-east, across central Buchan (Synge, 1956; Connell and Hall, 1987), where a network of drainage channels formed at the retreating margin of cold-based ice (Merritt and Peacock, 2000) (Figure 8a) and eskers are sparse. In contrast, relatively fresh-looking morainic and glaciofluvial deposits are more common to the SW. It is suggested that the ice-limits associated with these moraines resulted from a significant regional re-expansion of ice following prolonged very cold conditions.

The configuration of retreat limits shown in Figure 8 around Elgin are consistent with a readvance of Moray Firth ice during the Elgin Oscillation (Peacock et al., 1968), when extensive lakes were ponded within lower Strath Spey and Glen Rinnes. The subsequent Ardersier Readvance is revealed by retreat limits around the inner Moray Firth (Merritt et al., 1995).

\section{A critical review of the lithostratigraphical and geomorphological records in NE Scotland and crucial parts of the offshore record}

\section{Evidence for glaciations predating the late Middle to Late Devensian.}

We focus on glaciation during the late Middle and Late Devensian, but NE Scotland is unusual in northern Britain in possessing a significant number of sites documenting earlier glacial and non-glacial events (Merritt et al., 2003 and references therein). Evidence for these older events will be reviewed elsewhere, but as several sites contain glacigenic units that were previously thought to be Late Devensian in age, a brief mention is given here.

Tills in NE Scotland have been attributed to earlier Devensian glaciations, as in Scandinavia (Mangerud et al., 2013), but none have yet been confidently ascribed to one. If the region was glaciated then, despite it having experienced minimal glacial erosion and deposition, some tills of this age should have been preserved considering the widespread survival of regolith, units of sand and gravel, periglacial structures and sediments, and palaeosols (Table 3). This may be due partly to 'accommodation' for most long sequences in the region have been preserved within channels, as at Kirkhill, but once filled hollows such as these cannot accommodate more sediment. 
Furthermore, many channels have a long history and tend to be re-used and flushed-out during subsequent glaciations. Those till units that have been reported to be of early Devensian age are not capped by organic deposits of certain MIS 3 age so a practical, parsimonious approach has been adopted by ascribing them to the late Middle to Late Devensian. Clearly more research is required, as for example at the Nigg Bay and Oldmill sites (Table 2), which include glaciofluvial outwash and glacideltaic deposits that have provided OSL age estimates of approximately MIS 4 age (Gemmell et al., 2007).

NE Scotland has a record of erratics of Scandinavian origin (principally Oslo Graben rhomb-porphyry and larvikite) recovered from glacigenic deposits (Read et al., 1923: Merritt et al.; 2003 and references therein) (Figure 3). Erratics of rhomb-porphyry recovered recently from till deposited by eastward flowing ice at both Kirkhill and Sandford Bay suggest that they have been recycled, having been introduced to the region prior to the Late Devensian (Merritt et al., 2003). It is presently unclear if they were deposited directly by Scandinavian ice although it is a recurring theme in the older literature that such ice once lay close to the east coast deflecting Scottish ice to both north and south (Merritt et al., 2003, figs 37 and 38).

Evidence for substantial east to south-east flow of ice from the Great Glen during the last glacial cycle.

\section{East of Inverness.}

Psammite-rich tills with few sandstone clasts commonly overlie diamicts containing abundant ORS lithologies (sandstone, siltstone and conglomerate) on the north-west-facing slopes overlooking the inner Moray Firth between Inverness and Forres (Horne and Hinxman, 1914; Horne, 1923). Material derived from ORS outcrops around the Loch Ness Basin was transported eastwards towards Grantown-on-Spey, onto ground up to at least $500 \mathrm{~m}$ OD on the Nairn-Findhorn watershed, and into the middle to lower reaches of the Nairn, Findhorn and Spey valleys (Horne, 1923; Sissons, 1967; Fletcher et al., 1993) (Figure 4). The final movement of ice, however, was towards the northeast, as indicated by fs 6 (Figure 7 ), the orientation of glacial striae and the clast-composition of the youngest tills (Fletcher et al., 1996). As the sandstone- and psammite-rich till units are now both believed to be Devensian in age (Duller et al., 1995), the earlier, south-eastward flow event should be considered in reconstructions of the last BIIS.

A key locality is the Dalcharn site (Table 2, Figure 4), 200 m OD (Merritt and Auton, 1990; Auton, 1993) where the lower, sandy, Athais Till F (AT) (formerly Dalcharn Lower Till) rests unconformably on the Dalcharn Palaeosol F (DPF) (Table 3). The DPF contains compressed and disseminated organic material containing pollen of full interglacial affinity reflecting the later stages of an interglacial cycle, possibly predating MIS 5e (Walker et al., 1992). The cryogenically and glacitectonically disturbed organic deposits occurred near the bleached top of a considerably weathered unit of gravel (Craig an Daimh Gravel) (CDG) (formerly Dalcharn Gravel). An older, weathered sandstonerich diamict (Dearg Till $F$ ) underlies the gravel. Samples collected from a unit of white, clayey, cryoturbated gravel with disseminated peaty material taken 
from beneath the uppermost organic part of the DPF have yielded maximal luminescence ages of 68 and 50 ka (Duller et al., 1995). The ages are consistent with an infinite radiocarbon date of $>41.3 \mathrm{ka}$ obtained from a bulk sample of the organic unit above, but suggests that the thermophilous arboreal pollen in the DPF must be either allochthonous (Whittington, 1990) or reworked. The DPF is unlikely to be a glacial raft for it is part of a coherent weathering profile within the CDG that can be traced laterally for at least 400 m (Figure SI 14) (Bloodworth, 1990). The severity and depth of the weathering profile (over $3 \mathrm{~m}$ ) begs comparison with the Troutbeck Palaeosol in Cumbria, England (Boardman, 1985), which like the DPF is of complex origin, but likely to be the result of a considerable period of temperate conditions including the Ipswichian and earlier interglacials.

The Athais Till overlies the Moy Peat Bed (MPB) at the Moy (Allt Odhar) site, some $9 \mathrm{~km}$ to the south, at $371 \mathrm{~m}$ OD (Table 2; Figure 4) (Merritt, 1990, 1993; McMillan et al., 2011). This compressed bed of fibrous peat contains pollen, plant-macrofossils and coleopteran remains that reveal climatic deterioration during an Early Devensian interstadial (Walker et al., 1992). Similar to the Dalcharn Palaeosol, the MPB rests on gravel, which in turn overlies an older sandstone-rich diamict (Suidheig Till F), but the weathering profile is far less developed. Samples collected from sand-rich lenses within the MPB have yielded luminescence ages of between 37 and $58 \mathrm{ka}$ that were considered to be reliable and consistent with a finite radiocarbon age of $47.7 \mathrm{k}{ }^{14} \mathrm{C}$ a BP obtained from the alkali insoluble component of samples of the MPB (Duller et al., 1995). However, three concurrent radiocarbon age determinations were infinite $\left(>51.1 \mathrm{k}{ }^{14} \mathrm{C}\right.$ a BP) (Walker et al., 1992). The time span of $20 \mathrm{ka}$ between the TL ages for the top and bottom of the MPB is difficult to accept, but not totally at variance with the entomological palaeoenvironmental evidence. However, the TL ages are inconsistent with an experimental Useries disequilibrium measurement of $106 \mathrm{ka}$ for the MBP (Heijnis and van der Plicht, 1992). On reflection, a Middle Devensian age is possible for the Moy Peat Bed, especially as pollen grains of Bruckenthalia spiculifolia (Balkan heath) were not present (M.J.C.Walker pers.comm.). This species has been reported from Early Devensian interstadial deposits in Scotland (Whittington, 1994), but at much lower altitudes.

The Athais Till at Dalcharn has a till fabric indicating ice flow towards the south-east (Merritt and Auton, 1990; Walker et al., 1992; Auton, 1993), which is compatible with the pathways of indicator erratics (Figure 4). No flowsets of this antiquity have been identified in the vicinity by Hughes et al. (2014), although fs. 92 in the lower Findhorn valley, south-east of Forres, does have a parallel orientation (Figure 7). It is tempting to correlate this flowset with the Athais Till, but Hughes et al. (2014) conclude that ice flowed in the opposite direction. Fs.92 is constrained by very few landforms and its relative age is uncertain (Table 1). Circumstantial evidence for early east to south-easterly, uphill flow has been obtained from the Clava site nearby (Table 2; Figure 4, at $150 \mathrm{~m} \mathrm{OD}$ ). Clava is famous for occurrences of 'arctic' shelly clay and diamict that have been interpreted either as glacial rafts or parts of an in situ raised cold-water marine deposit (Gordon, 1993a). The former origin is more likely (Merritt, 1992; Phillips and Merritt, 2008; Merritt et al., 2014). The shelly clay 
contains well preserved, high-boreal to low-arctic, shallow-water marine shells that have yielded amino acid racemerisation (AAR) ratios not younger than the mid-Devensian (Merritt, 1992). Furthermore, an associated folded raft of pebbly diamict containing fragments of Portlandia arctica, an indicator of shallow-marine, fully arctic conditions, yielded a radiocarbon age of $>47.1 \mathrm{k}$ cal a BP. Merritt (1992) concludes that the sediment forming the rafts was originally deposited in Loch Ness, a marine fjord during the early Devensian. The rafts were detached and transported eastwards upslope owing to a powerful build-up of ice to the north-west. The age estimates further constrain the maximum age of this early flow event. At Clava the rafts of shelly clay and diamict are overlain by the Finglack Till $F$, deposited by ENE directed ice in general accord with glacial striae in the vicinity (Fletcher et al., 1996) and fs. 6 (Figure 7). The Athais Till is apparently absent, probably because it was eroded away beneath the Moray Firth Ice Stream during the creation of fs. 6 , when it shrank and down-cut to create flights of benches, ice-marginal drainage channels and corrugations on Drummossie Muir that are possibly megagrooves (Fletcher et al., 1996; BGS, 1997).

The Athais Till is well exposed in several valleys of streams draining towards the River Nairn, including the Clava site, where multiple sequences of diamict, glacitectonite, sand and gravel are exposed in river cliff sections up to $40 \mathrm{~m}$ high (Merritt and Auton, 1993: Fletcher et al., 1996, fig. 25). These sections have good potential for luminescence dating. The AT overlies weathered sandy diamict that probably correlates with the Dearg, Suidheig and Cassie tills at Dalcharn, Moy and Clava respectively: this unit locally rests on an even older, severely weathered till (Fletcher et al., 1996, fig. 25). Multiple sequences such as these may be expected in this western part of the region, which is likely to have been glaciated repeatedly during 'average' build-up of ice sheets during the Pleistocene (cf. Clapperton, 1997; Klemen, 1994).

\section{Lower Strath Spey.}

The east to south-easterly carry of ORS erratics is evident at least as far east as the Teindland site, within lower Strath Spey (Sutherland, 1993a) (Table 2; Figure 4). The Woodside Diamicton (formerly Teindland Till) (Table 3) overlies a truncated podzolic soil (Teindland Palaeosol) that contains pollen of thermophillous species and grasses assigned to the latter part of the Ipswichian Interglacial (Hall et al., 1995a). Luminescence ages of around 79 and 67 ka obtained by Duller et al. (1995) from the Badentinian Sand Bed (BSB) (Table SI 2) above the main organic horizons support the age suggested and were considered to be reliable by these authors. Although the genesis of the Woodside Diamicton is unclear, the presence of an isoclinal fold and shear zones within the sand bed strongly suggest post-depositional glacitectonism (Merritt et al., 2003; Connell and E.R. Phillips, unpublished). It follows that the uppermost part of the BSB may have been eroded and thus the TL dates could significantly predate the initial glaciation of lower Strath Spey during the last glacial cycle. However, a parsimonious interpretation would suggest that glaciation occurred soon after deposition of the BSB. As at Dalcharn and Moy, the palaeosol is developed on gravel that overlies an older diamict (Red Burn Till). 
A condensed sequence occurs at the original Teindland site, but three younger till units have been identified above the stratigraphic level of the palaeosol in the vicinity (Hall et al., 1995a) (Table 3). The oldest is the dark grey Altonside Till, which is exposed in a river cliff section of the River Spey at Tofthead (Table 2). It includes pebbles of Mesozoic mudstone and sandstone from the Moray Firth Basin and both the provenance and fabric of the till indicate former ice flow towards the south-east (Table 4). The Altonside Till, together with other dark grey diamicts (some shelly) recorded from boreholes drilled in lower Strath Spey (Aitken et al., 1979), thus probably correlates with the sandy Athais Till farther west (Table 3). If correct, the differences in colour, clast composition and matrix between the till facies simply reflects the bedrock over which the ice flowed during a regional south-easterly flow event(s) of ice from the Moray Firth.

\section{Evidence for south-east flow of ice from the Moray Firth across the} Banffshire coast and Buchan.

The isolated masses of dark grey, shelly diamict that occur beneath younger tills from Strath Spey south-eastwards to Aberdeen have been assigned to one allostratigraphical unit, the Whitehills Glacigenic Formation (WGF), within the Banffshire Coast and Caithness Glacigenic Subgroup (Peacock and Merritt, 1997; 2000a) (Figure 5, Table 3,3). The shelly deposits are generally capped by till containing clasts derived from the west or west-north-west, as at the Boyne Quarry, Castlehill of Gardenstown and King Edward sites (Jamieson, 1906; Read, 1923; Peacock et al., 1968; Hall et al., 1995a; Merritt et al., 2003) (Table 2; Figure 8). The tills incorporate ice-worn Pleistocene shell fragments in addition to abundant reworked, predominantly, Early Jurassic to Early Cretaceous fossils and palynomorphs (Riding, 2003). Blocks and large glacial rafts of Permo-Triassic and Lower Jurassic to Upper Cretaceous rocks are commonly enclosed within the shelly diamict. For example, mudstone rafts within the WGF were large enough to support brick and tile works at Whitehills, west of Banff, Tochieneal, south of Cullen and Plaidy, north of Turriff (Read, 1923). Large Jurassic erratics were formerly exposed at Atherb and Brucklay Castle, to the SW of Strichen (Jamieson, 1906), rafts of Late Jurassic black lignitic clay are described at Ardglassie , SSE of Fraserburgh (Merritt and Connell, 2000b) and ammonite-bearing black mudstone at the Oldmill site (Table 2) (Merritt and Connell, 2000a: Riding 2003).

Amino acid (AAR) ratios and radiocarbon dates on shell fragments collected from the WGF, mostly at the King Edward site (Table 2), suggest that the shelly components of the formation are derived from cold-water marine muds of Early to Middle Devensian age (Miller et al., 1987; Peacock and Merritt, 1997; Hall and Peacock, 2000; Peacock, 2000a; Bowen et al. (2002). More specifically, the ratios correlate with the Bø Interstadial of Norway (Mangerud et al., 1981), for which ages from 40 to 80 ka have been proposed by Miller et al. (1983), the higher estimates being favoured by Sejrup et al. (2000). No material dating to the younger Ålesund Interstadial of the Norwegian sequence has been reported in the WGF, suggesting that the last BIIS first expanded across the Moray Firth in the later part of the Middle Devensian. However, younger AAR ratios have been derived from shelly till at Dunbeath, in Caithness (Hall et al., 2011). It is not possible to fully establish the age of 
the WGF owing to poor exposure and some rafts and shelly deposits may have been deposited during pre-Devensian glaciations (Merritt et al., 2003).

Probable correlatives of the Whitehills Glacigenic Formation have been reported at several sites north of Aberdeen. For example, at Kirkhill and Leys, where large masses of dark grey clay (Corse Diamicton Member) consisting mainly of crushed mudstone bearing dinoflagellate cyst assemblages of Late Jurassic to Early Cretaceous age lie above a cryoturbate (Corsend Gelifluctate Bed) (CGB) deposited on the truncated Fernieslack Palaeosol Bed (Connell et al, 1982: Connell, 1984, p.69, Hall and Jarvis, 1993a), of likely Ipswichian age (Duller et al., 1995) (SI Table 2). The period of time represented by the CGB is unknown and hence the age of emplacement of the Corse Diamicton. At the Bellscamphie site (Table 2), near Ellon, the 'indigo' till of Jamieson 1906 and/or Pitlurg Till of Hall and Jarvis (1993b; 1995) underlies red diamict. The igneous and metamorphic clasts in these dark grey tills are likely to have been derived from the gneisses, gabbros and norites that crop out to the NW of Ellon (Figure 3), but the ammonite recorded by Jamieson (1906) and dinoflagellate cysts recovered by Hall and Jarvis (1995) and Riding (2003) both indicate derivation ultimately from the Moray Firth Basin west of Fraserburgh. However, although a weak north-south clast fabric has been detected in the Pitlurg Till by Hall and Jarvis (1995), direct transport from the north-west through to the north-east is difficult to accept because the till contains few, if any, pebbles of flint and quartzite from the Buchan Ridge Gravels, to the north (Merritt et al., 2003, fig. 2). Shell fragments of mixed populations in the Pitlurg Till have yielded AAR ratios of MIS 7 and MIS $5 \mathrm{e}$ age (Bowen and Sykes, 1988) suggesting, but not proving that the till correlates with the WGF. The Anderson Drive Diamicton found near the Bridge of Dee, in Aberdeen, is also shelly (Bremner, 1934a, 1943; Hart, 1941). It is no longer exposed, but at Nigg Bay (Table 2), some $4 \mathrm{~km}$ to the ENE, the Nigg Bay Till Member contains a rich palynoflora with a conspicuous Jurassic component (Riding, 2003) believed to have been entrained from the outcrop of Anderson Drive Diamicton. The Nigg Bay Till is otherwise a typical westerly-derived, sandy till with metamorphic and igneous erratics from inland (Table 4).

The scarcity of distinctive flint and quartzite clasts in the Pitlurg Till suggests that the ice was cold-based as it flowed across Buchan. This would explain the general absence of south-east orientated subglacial landforms there (Hughes et al., 2010). Furthermore, a large raft of ammonite-bearing Jurassic mudstone set into the base of the Whitehills Glacigenic Formation was observed to rest directly on undisturbed, weathered, cross-stratified, glaciofluvial sand and gravel with possible ice-wedge casts at the Oldmill site (Merritt and Connell, 2000a, fig. 32), to the north of the Buchan Ridge, indicating that minimal subglacial deposition of till accompanied the initial flow of ice from the Moray Firth. The emplacement of the Corse Diamicton directly upon the Corsend Gelifluctate (hosting at least one ice wedge cast) at Kirkhill and Leys (Table 3 ) reinforces the conclusion that the ice advanced across frozen ground. 
The Jurassic material in the Whitehills Glacigenic Formation and its correlatives is derived either from the northern shores of the Moray Firth, around Brora, or from strata cropping out beneath the firth (Jamieson 1906; Read 1923; Bremner, 1928, 1934a). Quantitative palynology of samples taken from the thickly developed WGF at Oldmill quarry indicate the main age diagnostic component of the palynofloras are of Jurassic origin, with little contribution from younger Mesozoic rocks (Riding, 2003). This assemblage suggests that ice flowed eastwards along the southern coast of the Moray Firth, crossing Jurassic outcrops offshore, before turning SE and E across Buchan.

Further evidence of an 'early' SE ice flow comes from the work of Synge (1963), Murdoch (1977) and McLean (1977) to the west and north of Aberdeen, on BGS Sheet 77 . All three authors recorded tills with SE directed clast fabrics and associated striae on bedrock. Murdoch and McLean both recorded an older till in gas pipeline trenches with SE orientated fabrics and NW derived erratics, though the unit was generally thin and restricted to bedrock depressions. In all cases this older till was overlain by a till unit with westerly derived clasts and a generally ENE clast fabric. At the more recently studied site at Kingwells, west of Aberdeen city, these two till units have been named the Denburn and Kingswells members respectively (Merritt et al., 2003; Table 4). The two till units have been recorded over a distance of some $15 \mathrm{~km}$ and are now considered to date to the late Middle to Late Devensian, although Sutherland (1984) speculated that the lower till may be older. At the Kingswells site, and in the boreholes drilled for the outer Aberdeen ring road, there is no evidence of a significant discontinuity between these two till units.

The western limit of material derived from the floor of the Moray Firth is shown in Figure 5. SE-directed striae reported to the west of this limit suggest that Grampian ice was deflected parallel to this boundary. For example, Bremner (1920b) recorded SE and SSE-directed striae on the interfluve lying between Banchory-Devenick and Cove Bay, south of the River Dee, and found erratics of Binn Hill gabbro on the coast south of Aberdeen (Figure 3). Furthermore, Francis Synge (pers. comm. to ERC in 1980) recorded SE-orientated striae on the NE flank of Bennachie at C. $335 \mathrm{~m}$ OD (Figure 7), which demonstrates that the ice was thick.

Evidence for the south-eastward flow event comes mainly from tillprovenance, till-fabric and SE-directed striae recorded around Elgin (Merritt et al., 2003, map 1) and Banff (Merritt et al., 2003, map 3). It is possible that some components of fs.72, in eastern Buchan, together with some icemoulded rock features associated with fs. 92, SE of Forres, may have formed contemporaneously (Figure 7; Table 1). The south-easterly directed flowset identified by Hughes et al. (2014) in Angus (Figure 7, fs. 7) certainly invites correlation with this stage (Table 1). It requires thick cover over the eastern Grampians to drive ice across the Vale of Strathmore and over the Sidlaw Hills, at up to $455 \mathrm{~m}$ OD. However, the antiquity of fs. 7 is unclear (Hughes et al., 2014) and older units of grey diamict containing Mesozoic erratics do occur in NE Scotland (Hall and Connell, 1991; Merritt et al., 2003) (SI Table 2) indicating that south-eastward flow of ice from the Moray Firth occurred during more than one glaciation. 
Evidence for an abrupt switch in ice flow direction following the early south-easterly flow event.

East of Inverness.

Based on thorough, systematic logging of natural sections on geological sheet 84W (BGS, 1997), east of Inverness, Merritt and Auton (1993) found that the contact between the sandstone-rich and overlying psammite-rich tills was generally represented by a sharp change in colour and commonly by a planar, sub-horizontal discontinuity. No major unconformities, distinct weathering profiles, palaeosols or organic deposits were found that could be linked with a complete deglaciation, but the common presence of wedge-shaped pull-apart structures, truncated gravel-filled channels, seams of glacitectonite and rip-up clasts of diamict suggest that ice-bed boundary conditions changed during the switch in flow (Fletcher et al., 1996; Walker et al., 1992), the ice-sheet possibly becoming more wet based. The sandy tills generally appear to be more weathered, but this may reflect their greater permeability or inclusion of previously weathered material.

At Dalcharn the sandy Athais Till is overlain by two members of the Beinn an Uain Till Formation (Table 3) that contain an increasing proportion of psammite upwards and fabrics that indicate a switch in flow first towards the east and then NNE (Walker et al., 1992). Both the fabric and provenance of the upper, Ruallan Till M supports correlation with fs.34 (Figure 7). This TT flow line is associated with ice that flowed from a centre in the western Highlands via upper Strath Spey to the vicinity of Grantown-on Spey. Flow was then concentrated across a gap in the Spey-Findhorn divide at Beum a' Chlaidheimh (Figure 4), at c. $360 \mathrm{~m} \mathrm{OD}$, as ice flowed northwards towards the Moray Firth via Lochindorb (Merritt et al., 2013). Considering the elevation of the gap and surrounding mountains, fs.34 must have shut down soon after deglaciation of the Cairngorm tops commenced at c. 21.3ka (Phillips et al., 2006) and an outlet glacier became established in upper Strath Spey creating fs.47 (Figure 7). Cosmogenic ages of c. 17.1ka on a rock glacier in Strathnethy (Phillips et al., 2006; Ballantyne, 2010) therefore provide only a minimum age for fs.34.

Banffshire and Buchan.

Like the Athais Till, the Whitehills Glacigenic Formation generally has a gradational upper contact with tills of contrasting provenance indicating a switch in ice flow direction unrelated to any deglacial event. For example, at Boyne Quarry there is corroborative structural evidence and striae indicating that the WGF was deposited by ice flowing southwards yet the overlying diamict (Old Hythe Till F) contains clasts of westerly provenance except for boulders of troctolite recycled or brought by a circuitous route from the south (Gordon, 1993b; Peacock and Merritt, 2000a; Peacock and Merritt, 2000b; Merritt et al., 2003). At the Castlehill site (Table 2 and 2) the sheared and icethrusted WGF is locally overlain by a thin unit of diamict (Crovie Till $F$ ) containing well-rounded pebbles most likely derived from ORS conglomerate cropping out to the south-west. At both sites the tills overlying the WGF can 
therefore be correlated tentatively with fs. 36, indicating that an abrupt switch in ice flow occurred.

Important evidence comes from the Kirkhill and Leys sites where the mudstone-rich Corse Diamicton underlies the Hythie Till Formation (HTF) (Table 3 and 3). Based on its relative age and provenance, the Corse Diamicton invites correlation with fs. 72. Although Hughes et al. (2014) suggest that fs. 72 cuts fs. 36 (Figure 7; Table 1), the latter set could be older because it has a much less clear geomorphological signature and no crosscutting landforms have been identified. Fs. 36 is confidently correlated with the Hythie Till (EGGS), which contains clasts derived mainly from the west and south-west. The former quarry at Kirkhill is situated within a rock-cored drumlinoid ridge trending WSW-ENE and other ice-moulded features in the area are similarly orientated (Merritt et al., 2003, map. 6). As a note of caution, however, felsite dykes like that which was formerly quarried at Kirkhill lie in the same orientation.

At Oldmill, the WGF and its included rafts are overlain gradationally by a thin unit of diamict that is correlated with the Hythie Till as it contains erratics from the west and a weak 'west to east' fabric (Merritt and Connell, 2000b). Farther south, in the Aberdeen area, the Den Burn Till is overlain by a range of younger till facies that occur at the surface, or beneath glaciofluvial sediments over a significant area. These younger tills, the Kingswells and Nigg Till members of the Banchory Till Formation (Table 4) were generally deposited by ENE flowing ice with no major discontinuities between the older and younger units. Both striae and clast fabric measurements suggest flow fluctuated between E and ENE, which is compatible with fs 64 (Figure 7).

\section{Evidence for ice flow from Strathmore up the eastern coast of Buchan}

It is generally accepted that ice formerly flowed north-eastwards along the coast from Strathmore (Jamieson, 1906; Bremner, 1916; Synge, 1956; Clapperton and Sugden, 1977; Merritt, 1981; Hall, 1984; Munro, 1986; Hall and Connell, 1991). Glacial striae locally provide evidence of NNE-directed ice flow (Jamieson, 1882a, 1906; Bremner, 1916), notably near Nigg Bay (Merritt et al., 2003, map. 9) and high on the hillside overlooking Boddam, south of Peterhead (Jamieson, 1882a, 1906; Merritt et al., 2003, map. 7). Red sandy textured tills of the Mearns Glacigenic Subgroup (MGS) (Table 4) were laid down by ice flowing in this direction (Bremner, 1920a), but possibly on more than one occasion. We have identified silty clay-rich red till as far north as Netherhill Farm, c. $7 \mathrm{~km}$ NNW of Peterhead, where it is capped by grey diamict belonging to the BCCGS. At Nigg Bay, Cove (Jamieson, 1882a and Findon (Synge, 1963) (Merritt et al., 2003, map 9 and 11) red till locally rests on grey till of western provenance indicating that East Grampian ice formerly flowed offshore before being replaced by Strathmore ice. Gradational contacts between the tills suggest that they were laid down during the same (MiddleLate Devensian) glaciation. This flow event is correlated with fs. 51 (Figure 7), which Hughes et al. (2014) conclude is isochronous. 
The direction of ice flow subsequently changed from NNE to ENE as the Strathmore ice stream became dominant, creating fs. 56 (Figure 7). The presence of red tills of the MGS in the mouths of most valleys draining the southern flank of the eastern Grampian Highlands, such as Glen Clova and Glen Esk (Bremner, 1934b, 1936; Synge, 1956), and at Balnakettle (Table 2), $4 \mathrm{~km} \mathrm{NW}$ of Fettercairn, indicate that Strathmore ice either forcibly pushed back ice occupying the valleys to the north, or that the ice within them had already begun to thin and retreat, enabling Strathmore ice to advance towards the mountains (Figure 5). The sequence of events at Balnakettle may be more complex, because East Grampian ice subsequently expanded back towards Strathmore (Merritt et al., 2003) and Hughes et al. (2014) recognise a NNEdirected flowset in the area (fs. 93), which is cut by, and is therefore older than fs. 51 (Table 1).

\section{Evidence for an onshore re-advance of ice into Logie-Buchan}

Ice sourced in Strathmore encroached onshore between Aberdeen and to the north of Peterhead following the creation of fs. 51 and the aforementioned NNE striae near Boddam. It laid down a distinctive suite of deposits in LogieBuchan (Figure 5) (Jamieson, 1906; Bremner, 1916; Synge, 1956; Clapperton and Sugden, 1977; Merritt, 1981; Hall, 1984; Munro, 1986; Hall and Connell, 1991; Merritt et al., 2003, fig. 50) with clast fabrics in diamicts of the Hatton Till Formation indicating flow towards the NNW. The onshore movement is confirmed by the clay mineralogy of the L-BGS (Glentworth et al., 1964) likely derived from Triassic mudstones (Figure SI 12) together with glacial erratics derived from the floor of the North Sea Basin immediately to the east, including Permian dolomite, Mesozoic limestone and calcareous siltstone, shelly sandstone (Crag) (Jamieson, 1882b) and shell fragments of early Pleistocene and younger age derived from the Aberdeen Ground Formation offshore (Merritt et al., 2003: Stoker et al., 2011). ). Quantitative palynological analyses of samples from this unit contain rich assemblages dominated by Jurassic forms with less common Permian pollen and sparse Carboniferous and Cretaceous/Palaeogene forms (Riding and Stephenson, 2001). This enigmatic onshore flow direction led to the deposition of a swathe of relatively 'fresh' hummocky topography formed of vivid reddish brown, interbedded diamict, clay, micaceous silt, sand and gravel. Topography bears little relationship to the sub-drift surface and laminated silts and clays overlying buff-coloured, pebbly sands with shell fragments commonly occur at the base of the sequence within hollows (Merritt, 1981). This complex landformsediment assemblage typical of ice disintegration either relates to a local glacial reorganisation during the decay of the ice stream responsible for fs 51 after the ice sheet had thinned considerably, or to a subsequent readvance (Clark et al., 2012). For convenience the event is named here as the LogieBuchan Readvance. The Kippet Hills Esker (Figure 8; Table 2) (Gordon, 1993c) was deposited by water flowing NNW (Merritt et al., 2003), most likely in the general direction of ice flow during stagnation and decay of this coastal ice lobe.

Recent interpretation of the glacial deposits exposed in Sandford Bay (Table 2) (Hall and Connell, 1991; Merritt et al., 2003), south of Peterhead, broadly 
confirms Jamieson's (1906) final conclusion that early expansion of ice from inland to, if not beyond the present coastline was succeeded by the deposition of a glaciolacustrine sequence (Ugie Clay Formation) (UCF) that received sediment both from the westward-retreating East Grampian ice sheet and northward-advancing Logie-Buchan ice. Subsequently the latter advanced onshore and deposited a thick till complex including rafts of dark grey, shelly, clayey diamict. The ice advanced over $5 \mathrm{~km}$ inland into the lower Ugie valley, west of Peterhead, damming meltwater to create an extensive proglacial lake (Glacial Lake Ugie) (Figure 8). Reddish brown silt and clay of the UCF widely underlie the floodplains and glaciofluvial terraces associated with the North and South Ugie waters (McMillan and Aitken, 1981) and at Baluss Bridge (Table 2) the UCF includes thinly interbedded reddish brown and dark grey plastic clay, the latter yielding rich Palaeozoic and Mesozoic palynomorph assemblages (Hall, 1984; Hall and Connell, 1991). Similar laminated organic deposits occur at Errollston (Peacock, 1984; Connell et al., 1985; Merritt et al, 2003) (Table 2), near Cruden Bay.

A lobe of ice advanced onshore up the valley of the River Ythan, where it laid down red diamict (Hatton Till $F$ ) on till of inland provenance at Bellscamphie (Table 2), north-east of Ellon, and at a number of other nearby sites (Hall and Jarvis, 1995). The advance terminated close to the Cross-Stone site, south of Ellon (Table 2; Figure 8), where a pair of crescentic, asymmetrical end moraines were formed (Merritt et al., 2003). As in the Ugie catchment, East Grampian ice had retreated sufficiently to allow a substantial glacial lake to form in the Ythan valley upstream of Ellon (Merritt, 1981; Hall, 1984) (Figure 8). In the Aberdeen area, however, masses of red diamict locally occur within a grey-brown till of western provenance and vice versa (Bremner, 1916; Munro, 1986; McLean, 1977; Auton and Crofts, 1986; Merritt et al., 2003), which led Clapperton and Sugden (1977) to conclude wrongly that the ice responsible for laying down the L-BGS was wholly in contact with East Grampian ice.

The inland margin of the L-BGS can be traced north-eastwards from the Ythan valley towards the Den of Boddam (Figure 8), at about $80 \mathrm{~m} \mathrm{OD}$, before descending to about $50 \mathrm{~m}$ OD to the west of Peterhead. The Den has a long history but finally carried meltwater north-eastwards towards Sandford Bay. Red tills overlie yellowish brown and grey tills of western provenance between Ellon and Peterhead (Wilson, 1886; Jamieson, 1906; McMillan and Aitken, 1981) and at Downiehills (Merritt et al., 2003, map 7) Jamieson (1858) recorded large blocks of Peterhead Granite in reddish brown till together with shell fragments. He noted dark blue clay 'intermingled' with red deposits in a former claypit at Ednie (Jamieson, 1906) (Merritt et al., 2003, map 7), whereas the red till had been observed to enclose irregular masses of 'dark grey till' and 'dark blue clay and sand' by Wilson (1886). These observations have caused confusion for on one hand they have been taken to support the view that deposits of Moray Firth and North Sea derivation are intermingled and of approximately the same age (Jamieson, 1906; Hall and Connell, 1991). The alternative view is that older blue-grey sediments have been incorporated into the red glaciotectonically by a later, northward movement of ice (Sutherland, 1984). This view is supported by evidence reported from 
temporary exposures at Invernettie, near Sandford Bay, that revealed very dark grey, calcareous, shelly, clast-poor, clayey diamict forming rafts up to 2.0 $\mathrm{m}$ thick and over $50 \mathrm{~m}$ in length (Merritt et al., 2003). The rafts were disrupted by south dipping, low-angle, thrust faults. Darker colours predominated close to the rafts, passing outward into the vivid reddish brown colours of the host diamict suggesting that the rafts were in the process of being 'digested'. Analysis of the diamict forming the rafts showed it to be rich in Late Jurassic to early Cretaceous palynomorphs (Riding, 2003). Though thrust from south to north, the grey diamict had an original provenance to the north or NW of the site in the Moray Firth.

The precise sequence of events is difficult to establish for the stratigraphic record in eastern Buchan is complex. For example, a small ice-free enclave possibly opened up in eastern Buchan late in the previous stage during icesheet thinning, occupied by Glacial Lake Ugie at its $80 \mathrm{~m}$ level, in the lee of the confluence of Strathmore and Moray Firth-sourced ice (Peacock and Connell, 2000) (Figure 8). Evidence for the $80 \mathrm{~m}$ lake is restricted to the valley of the North Ugie Water, where Moray Firth ice formed a narrow, ESEtrending morainic ridge adjacent to the $80 \mathrm{~m}$ lake near Strathstodley, east of Mormond Hill (Peacock, 1997; Merritt et al., 2003, map 7). Glaciolacustrine deposits of the UCF were overlain by glaciodeltaic and glaciofluvial terrace gravels as lake levels fell from 80 to $50 \mathrm{~m}$ OD. The gravels subsequently became permanently frozen with the formation of tundra polygons (Gemmell and Ralston, 1984; Ballantyne and Harris, 1994). No exits have been identified for the $80 \mathrm{~m}$ and $50 \mathrm{~m}$ glacial lakes in the lower Ugie catchment, and since the ground lies below $50 \mathrm{~m}$ OD towards both the north and east coasts, the lakes must have been dammed by coastal ice sourced both in the Moray Firth and North Sea basins.

The Ugie terrace gravels have yielded OSL ages in the range of 76 to $108 \mathrm{ka}$ (Gemmell et al., 2007). These dates are anomalously old as the gravel terraces partly overlie laminated silt and clay laid down in Glacial Lake Ugie (Ugie Clay F) and several till units (McMillan and Aitken, 1981). Puzzlingly, the samples appeared to be well bleached. Furthermore, at Toddlehills (Table 2, Figure 8) glaciofluvial sand related to northward flow of water into Glacial Lake Ugie has yielded an OSL age of $31+/-2$ ka (Gemmell et al., 2007). This age is more in keeping with the stratigraphical evidence at the site, but may still be too old.

Further problems surround a curious suite of hummocky sandy deposits, the Auchleuchries Sand and Gravel Formation (ASGF) (Table 3), that straddles the boundary between the L-BGS and EGGS to the south of the 'Buchan Ridge' (Merritt et al., 2003). At the Hill of Auchleuchries (Merritt et al., 2003, fig. 50), where Jamieson (1882, p.172) recovered a rich shell fauna, the sands are capped by yellowish brown till of probable western derivation, whereas to the north and west of Hatton they are capped by red till of the L-BGS (Merritt, 1981). The sands contain conspicuous amounts of pink (Peterhead) granite, but surprisingly little flint and quartzite from adjacent outcrops of the Buchan Gravels Formation (Merritt et al., 2003). The sands overlie dark grey till with shell fragments correlated with the Pitlurg Till at Bellscamphie (Table 2), deposited by ice flowing from the ENE (Bremner, 1928; Hall and Jarvis, 
1995). The pink granite clasts in the pebbly sands together with of seams of fissile, chocolate brown to olive grey clay (Merritt, 1981) either also suggest derivation from this direction, or reworking of older material. It may be concluded that there was complex interplay between ice sourced from the Moray Firth and the North Sea basins following retreat of East Grampian ice across eastern Buchan.

At the Burn of Benholm site, between Stonehaven and Montrose (Table 2), shelly diamict of the Benholm Clay Formation (BCF) was laid down by ice flowing onshore from the North Sea Basin, probably during MIS 6 (Merritt et al., 2003) (Table 3). A lens of peat embedded in the base of the overlying red Mill of Forest Till Formation has been assigned to MIS $5 \mathrm{a}$ or $5 \mathrm{c}$ (Campbell, 1934; Auton et al., 2000), thus providing a maximum age both for the till and fs. 51 with which it is correlated.

Evidence surrounding the retreat of Strathmore ice from the Aberdeenshire coast and marine incursion.

It is generally believed that the Logie-Buchan Readvance was followed by sequential 'un-zipping' down the North Sea coast of 'Strathmore' ice, and ice sourced more locally in the East Grampians (Simpson, 1955). There was certainly widespread ponding between East Grampian and Logie-Buchan ice to the north of Aberdeen, where subaqueous fan and glaciofluvial deltaic deposits abound (Aitken, 1995), for example at the Strabathie (Thomas, 1984: Thomas and Connell, 1985) and Mill of Dyce sites (Aitken, 1998) (Table 2) (Merritt et al., 2003, map 9). That this ponding was closely followed by a marine incursion is suggested by various reported finds of the bones of whales, seals and birds in isolated, locally fossiliferous deposits of red and brown silt and clay overlying glaciofluvial deposits up to about $30 \mathrm{~m}$ OD (Peacock, 1999; Merritt et al., 2003). In the Aberdeen area these deposits, assigned to the Tullos Clay Member (Table 3), were exploited in former clay pits at Tipperty (Bremner, 1943; Munro, 1986), Blackdog (Jamieson, 1906; Bremner, 1916; Peacock, 1975), between Torry and Tullos Hill (Simpson, 1948), and at Nigg Bay (Table 2) (Merritt et al., 2003, map 9). As similar clays described at the Errolston site (Peacock, 1984) (Table 2) (Merritt et al., 2003, map7), near Cruden Bay, contain numerous reworked microfossils and other materials, further work is required to confirm the marine invasion. However, presence of roughly E-W orientated linear ridges lying closely offshore (Figure 8) and interpreted as De Geer moraines (Bradwell et al., 2008, fig. 5) suggests that the 'Strathmore' ice calved into a marine embayment that had opened up from the north. These features, with average wavelengths of 200 $\mathrm{m}$ and heights up to $17 \mathrm{~m}$, have been interpreted as giant sand waves by Gatliff et al. (1994), but others lying $50 \mathrm{~km}$ to the east are anomalously large at least for present hydraulic conditions. Those ridges lying offshore from Ellon (Figure 8c) are matched by similarly orientated linear features immediately onshore (Hughes et al., 2010).

The 'unzipping' of the ice masses probably continued down the coast to the vicinity of Montrose, where Strathmore ice was able to flow directly seawards to create isochronous flow-set 56 (Figure 7). Strathmore ice apparently then 
retreated inland sufficiently to allow the accumulation of red marine clay to an elevation of c. 22 m OD at Lunan Bay. This Lunan Bay Clay Member of the Errol Clay Formation is capped locally by glacial outwash that includes thin beds of till (Rice, 1959). Controversially, McCabe et al. (2007) report AMS dates of 20,097 \pm 87 and 20,881 \pm 102 cal a BP (Hughes et al., 2016) on hand-picked, monospecific foraminiferids from the clay, providing a date for marine incursion, but the basis of their investigation has been questioned by Peacock et al. (2007) and Sejrup et al. (2009), who comment on how the dates are incompatible with youngest ages of c. 17.5ka for deglaciation of ground above $200 \mathrm{~m}$ on Mormond Hill and Pitfichie provided by cosmogenic techniques (Phillips et al., 2008). Although McCabe et al. (2007) incorrectly correlate the glaciofluvial deposit overlying the Lunan Bay Clay with the supposed Perth Readvance at Perth, there are insufficient grounds to discard their age determinations, which are at least 1000 radiocarbon years older than the oldest dates for late-glacial marine deposits obtained so far in the Firth of Tay (Peacock et al., 2007). Considering the importance of these dates further detailed stratigraphical work and sampling is required to resolve these issues.

\section{Evidence for late incursions of ice across Buchan from the Moray Firth Basin.}

There has been little consensus concerning how many times ice flowed onshore into Buchan from the Moray Firth Basin, but the last encroachment probably formed fs. 100 (Figure 7). This TT flowline probably correlates with calcareous blue-grey tills assigned to the Essie Till Formation (ETF) (Table 3), which crop out along the coast between Rosehearty and Peterhead, where most glacial striae, ice moulded features and erratics also indicate that the last movement of ice was towards the ESE or SE (Peacock, 2000b; Merritt et al., 2003, map 4). At St Fergus (Table 2) (Figure 8) the ETF overlies reddish brown diamict that was deposited by Logie-Buchan ice (Hall and Connell, 1991), whereas at Lumbs (Merritt et al., 2003, fig.10) a trial pit dug revealed $3.8 \mathrm{~m}$ of stiff, dark grey pebbly clay with lenses of reddish brown diamict, small masses of red clay, clasts of marl and red sandstone, and very sparse fragments of shell and chalk. The underlying red diamict contained granules of red sandstone and mudstone. The trial pit was dug into an isolated, drumlinoid hill trending NW-SE and both the glacial streamlining of the feature and the composition of the ETF indicate ice flow towards the SE, which accords with fs. 100. The ETF is possibly the 'blue oolite clay' with striated stones that was formerly worked at Lumbs (Milne, 1892). The red materials, black mudstones and chalk probably have been derived from the juxtaposed outcrops of Permo-Triassic and Cretaceous strata lying within the Moray Firth Basin to the north of Fraserburgh. This direction of transport is supported by the presence of boulders of an uncommon set of Lower Cretaceous siliceous malmstones, sponge-chert and fossiliferous glauconitic sandstone that have been collected from morainic deposits south of Fraserburgh (Cumming and Bate, 1933).

Several boreholes to the north of the River Ugie proved dark shelly diamicts that probably correlate with the ETF (McMillan and Aitken, 1981). For example, one $4 \mathrm{~km} \mathrm{NW}$ of Peterhead proved $5.4 \mathrm{~m}$ of dark bluish grey clayey 
diamict overlying $3.2 \mathrm{~m}$ of dark reddish brown diamict, both units containing clasts of red granite most probably derived from a small outcrop of coarsegrained pink granite to the north-west of Crimond or beneath part of the gas terminal at St Fergus (Merritt et al., 2003, map 7). The diamicts overlay $9.8 \mathrm{~m}$ of crudely laminated, red, reddish brown and yellowish-brown, micaceous silt assigned to the Ugie Clay Formation (see above). Both the red and grey diamict units therefore result from readvances of coastal ice across Glacial Lake Ugie after East Grampian ice had retreated westwards. Near Kirkhill the Essie Till locally truncates gravel containing erect pebbles suggesting that Moray Firth ice readvanced over frozen ground that had been deglaciated previously (Merritt et al., 2003, plate 8d).

The ESF probably correlates, at least in part, with grey-black till, over $23 \mathrm{~m}$ thick, proved beneath a veneer of shelly pebbly sand in BGS offshore borehole 72/31 (Owens and Marshall 1978; Evans et al., 1981), 13 km east of Peterhead. The diamict yielded Quaternary miospores and microplankton accompanied by a rich assemblage of reworked late Jurassic and early Cretaceous palynomorphs indicating a likely NW provenance for the deposit.

Evidence regarding the East Grampian ice sheet: correlation with flowsets 33, 36, 64 and 72.

The cumulative amount of glacial erosion decreases rapidly northwards into central Buchan (Hall and Sugden, 1987) where the sandiness and common relatively pale colour of the tills suggest that they are significantly weathered (Fitzpatrick, 1958, 1972) and hence may been laid down either during an early-Devensian glaciation (Sutherland, 1984; Hall and Connell, 1991), or an older one (Charlesworth, 1957; Synge, 1956). However, the sandiness and colour are more likely to result from the incorporation of significant proportions of deeply weathered bedrock unless biotite-bearing clasts are weathered too. Furthermore, pedological studies of till (correlated with the Hythie Till) near Mintlaw suggest that soil forming processes occurred solely during the Holocene though developed on a previously periglacially disrupted fabric (Van Amerongen, 1976). Where tills and subglacial landforms are poorly developed the last direction of ice flow across central Buchan may be inferred from the widespread, reticulate pattern of glacial drainage channels formed at the westward retreating margin of a cold-based ice sheet (Merritt and Peacock, 2000; Merritt et al., 2003, map 6; Clark et al., 2012). The identification of flowsets 36 and 72 only in the east of Buchan suggests that they are relatively older, as concluded by Hughes et al. (2014) (Table 1); they formed beneath the ice sheet when it was thicker and possibly became locally warm-based during a 'purge' event.

Ice-moulded bedrock features are mainly restricted to the valleys of the Don and Dee, which focussed ice flowing eastwards from the Cairngorms and created fs.64. The Banchory Till Formation (BTF) (Merritt et al., 2003) correlates with this TT-thinning flowset (Figure 7) as it contains clasts of westerly provenance (psammite, pelite, semipelite, granite and gabbro). Subglacial scouring is most pronounced towards the North Sea Basin, between the Ythan Estuary and Aberdeen (Hall, 1986; Hall and Sugden, 
1987), where roche moutonees, crescent-shaped erosional depressions ('moats') at the stoss-ends of crag-and-tail features and striae are relatively common (Merritt et al., 2003, map 8 and 9). The eastward flow of ice represented by fs. 64 became increasingly influenced by topography as the ice sheet margin retreated westwards, as indicated by the varying orientations of subglacial features and drainage channels and the fan-shaped distribution of striae and clasts fabrics (Merritt et al., 2003, map 8).

Four members of the Banchory Till Formation have been recognised in the Aberdeen area, notably around Nigg Bay (Table 3 and 3) and to the west and north-west of the city (Merritt et al., 2003). Ice advanced from the north

(Anderson Drive Diamicton) and north-west (Den Burn Till) before a strong ice flow from the west and south-west deposited the extensive Nigg and Kingswell members. These last two tills are lateral equivalents and locally grade up into, or are interbedded with tills of the Mearns Glacigenic Subgroup in the coastal zone, indicating some contemporaneous deposition associated with flowsets 51 and 64 . Fs. 64 cuts fs 51 to the south of Aberdeen (Figure 7), which is consistent with ideas of an 'Aberdeen Readvance'. Recent work in the north cliff of Nigg Bay, Aberdeen (Connell and Gemmell unpublished) has identified a thin ( $1 \mathrm{~m})$ till of inland provenance overlying coarse gravels of the Drumlithie Sand and Gravel Formation and itself overlain by more coarse gravels and sands. It is likely that this thin till unit represents a minor eastward readvance of the East Grampian ice sheet that created moraines and other ice contact landforms to the north and south of the city (Bremner, 1917; Merritt et al., 2003, map 9). This event followed at least a partial retreat of Logie-Buchan/Mearns ice.

\section{Evidence for a minor readvance of ice from the Moray Firth and the creation of the St Fergus Push Moraine.}

The late-glacial sea invaded the eastern coast of Buchan following the creation of fs. 100, deposition of the Essie Till Formation and the draining of $50 \mathrm{~m}$ Glacial Lake Ugie (Merritt et al., 2003). Glaciomarine deposits of the St Fergus Silts Formation (SFSF) were laid down around the Loch of Strathbeg and in the vicinity of the St.Fergus gas terminal (Hall and Jarvis, 1989; Peacock and Connell, 2000) (Table 2; Merritt et al., 2003, map 4 and 7). The SFSF comprises dark grey to dark greyish brown, laminated, calcareous mud with sand laminae and shell fragments (Peacock, 1999). The presence of dropstones of gneiss, chalk and red sandstone suggests a proximal glaciomarine environment adjacent to ice flowing across the Moray Firth Basin since Upper Cretaceous strata crop out on the sea floor only to the north or north-east of Fraserburgh. The SFSF generally rests on reddish brown diamict, but on the southeastern side of the gas terminal it rests on dark shelly till with chalk erratics (Hall and Jarvis 1989).

The surface elevation of the SFSF and associated raised beaches-imply a marine transgression to at least $12 \mathrm{~m}$ and possibly $15 \mathrm{~m}$ above OD (Peacock, 1997;

Peacock et al., 2000). Radiocarbon dates on marine bivalves provide ages of 17,652 \pm 250 cal a BP (Hall and Jarvis, 1989; Hughes et al., 2016) and 17,490 \pm 101 and $18,147 \pm 232$ cal a BP (Peacock, 1999; Hughes et al., 2016), adjusted using a marine reservoir age of $400 \mathrm{a}$. These dates have been questioned as being too young by Peacock et al. (2007) on the grounds that the shells were possibly chalky, but this is 
incorrect as they retained their original sheen. The SFSF poses a problem, however, because late-glacial raised beaches and marine deposits generally have been assumed to be absent in peripheral areas of eastern Scotland on theoretical grounds that the contemporary sea level was below OD (Sissons, 1976; Lambeck, 1995). Much more ice must have been present in the region than thought hitherto to cause the required glacio-isostatic depression at about 17-18 ka (Peacock, 1997). The additional ice load was probably mainly offshore in the Moray Firth Basin and to the north. The dates certainly suggest that ice remained active within the outer Moray Firth several thousand years after the initial marine incursion.

The surface level of the SFSF locally reaches $16 \mathrm{~m}$ OD within a low ridge that extends $5 \mathrm{~km}$ along the coast from Annachie towards Rattray Head (Merritt et al., 2003, map 4 and 7). Exposures of faulted, tilted and deformed masses of bedded silt and sand in the ridge led Hall and Jarvis (1989) to interpret the feature as a push moraine formed by a readvance of ice from the east or north-east. This conclusion is supported by borehole evidence that indicates that the SFSF passes under, and is therefore mainly older than the moraine feature. A cutting through the cliffline backing the Holocene raised beach also revealed faulted, tilted and sheared masses of bedded sand and black clay (Merritt et al., 2003). This St Fergus Push Moraine may be linked with arcuate ridge features offshore (Clark et al., 2012) (Figure 7).

There is related evidence of a significant readvance of ice from the north and east that affected a narrow coastal zone between Cairnbulg Point and St Combs, between Fraserburgh and St Fergus, where discrete NNW-SSE striations cross earlier WNW-ESE striations and glacial grooves (Peacock, 1997). Importantly, a sheet of glaciofluvial outwash descends to the Holocene raised beach at c $5 \mathrm{~m}$ OD (and possibly below this level). This suggests that ice was delivering meltwater south-eastwards towards St Fergus after relative sea level had fallen by at least $7 \mathrm{~m}$ from the time that the SFSF was deposited.

\section{Deglaciation of the northern coast of Banff and Buchan.}

Read (1923) provides convincing evidence for a sluggish, northerly 'encroachment' of ice that laid down his 'Northerly Drift'. It transported numerous boulders and blocks towards the coast, notably troctolite gabbro from outcrops to the west of Huntly (Figure 3). Such boulders are found in the Old Hythe Till at Boyne Quarry (Peacock and Merritt, 2000b), and are particularly common on Durn Hill, SW of the site, where he reports that some have been pushed from the south. Arcuate recessional moraine ridges occur to the south of Durn Hill together with northerly-orientated eskers (Figure 8), clearly recording retreat of this ice mass back towards the south, as deduced by Read (1923). This direction of ice retreat suggests correlation with a suite of subdued subglacial bedforms of NNW orientation that occur around Durn Hill and to the south of Boyne Quarry (Figure 8). These bedforms belong to fs.35, but they were deduced to have been formed by ice flowing in the opposite direction by Hughes et al. (2014) (Figure 7). This would reopen a long-standing debate regarding evidence for a final onshore readvance of Moray Firth ice (Read, 1923; Bremner, 1943; Peacock and Merritt, 2000a). However, although some crag and tail features suggest that ice flowed from 
the Moray Firth there are others that indicate it flowed in the opposite direction, which on balance is now considered more likely.

Read (1923) also describes a belt of glaciofluvial and glaciolacustrine deposits extending inland for no more than about $10 \mathrm{~km}$ between Portknockie and New Aberdour (Merritt et al., 2003, maps 2, 3 and 4). The suite is associated with several ice-marginal glacial drainage channels orientated parallel to the coast, clearly suggesting that ice lay closely offshore (Figure 8). These 'Coastal Deposits' (Read,1923) originally included dark grey shelly tills and clays now assigned to the Whitehills Glacigenic Formation (Peacock, 1971; Peacock and Merritt, 1997). The fluvioglacial deposits are now assigned to the Blackhills Sand and Gravel Formation (BSGF) (Peacock and Merritt, 2000d) and glaciolacustrine silts and clays to the Kirk Burn Silt Formation (KBSF) (Table 3).

At Castle Hill of Gardenstown (Figure 8; Table 2) the KBSF consists mainly of ochreous to dark olive brown, laminated to thin-bedded silts and clays up to about $10 \mathrm{~m}$ in thickness (Peacock and Merritt, 1997). Bands of ferruginous or calcareous nodules occur locally. The sediments show signs of settlement and minor slumping, but there is no evidence that they have been affected by a significant post-depositional glacial advance from inland as deduced by Read (1923), or that they are widely covered by solifluction deposits as described by Synge (1956). However, similar deposits have been deformed by ice pushing from seawards at Troup Head (Peacock and Merritt, 2000c). The KBSF was laid down during deglaciation, when East Grampian ice had retreated inland, but active ice remained in the Moray Firth Basin, forming a barrier along the present coastline beyond which lakes were ponded to the south (Figure 8). It seems that lakes first formed to the north of New Aberdour, draining eastwards along the coast. A larger lake then formed between Gardenstown and Pennan, draining via the Afforsk Spillway eventually into the valley of the Deveron (Figure 8). Much larger lakes formed subsequently between Portknockie and Macduff.

There are several localities along the coast where the Blackhills Sand and Gravel has been disturbed by a late-stage push of ice from the Moray Firth (Peacock and Merritt, 2000d), locally laying down thin beds of gravelly diamict named as the Arnhash Till Member (Table 3), as at New Aberdour (Merritt et al., 2003, map 4). Other sites include Gallows Hill, near Cullen (Merritt et al., 2003, map 2) (Bremner, 1928), Troup Head (Merritt et al., 2003, map 9) (Peacock, 1971) and Broomhead, SSW of Fraserburgh (Merritt et al., 2003, map 4). At Arnhash and Broomhead deltaic deposits have been pushed by ice nudging inland from the NW and NNE respectively (Peacock and Merritt, 2000d; fig. 26).

A crucial site for determining the glacial history of the coastal region is at the Howe of Byth, south of Pennan (Table 2, Figure 8), where quarry sections in a large gravel fan fed from glacial drainage channels to the north have been described by Hall et al. (1995b) and Hall and Connell (2000). The Auchmedden Gravel (AG) forms the upper part of the fan, resting on the Byth Till of western provenance. This generally thin reddish brown till rests on a lower unit of fan gravel, the Howe of Byth Gravel (HBG), from which Duller et 
al. (1995) obtained luminescence ages of c. 45.4 and 37.8 ka. Hall et al. (1995b) concluded that the gravels were ice-proximal, fed from ice lying along the coast to the north, although they are composed almost wholly of local, well rounded cobbles of ORS conglomerate. Both units of gravel have southerly directed palaeocurrents and it is clear from NextMap imagery (Figure 8) that at least the AG was deposited from water flowing eastwards via interconnected glacial drainage channels typical of those associated with westward retreating ice (Merritt and Peacock, 2000). The generally dense, matrix-rich, ferruginous HBG includes laterally discontinuous beds of diamict interpreted as debris flows, and several horizons of erect clasts, one immediately beneath the Byth Till (Hall and Connell, 2000). The HBG has the attributes of an alluvial fan that accumulated over a period of time including several periglacial episodes. However, the large size of the fan and the presence of ice-scratched pebbles suggest that it formed in close proximity to an ice front for a significant period of time.

Duller et al. (1995) judged that the grains sampled from the Howe of Byth Gravel for TL dating were completely bleached and thus yielded a reliable Middle Devensian age estimation. The deposit certainly looks old because it is ferruginous, but the iron may have been liberated by acid waters from ferruginous ORS conglomerate in the vicinity. Gemmell et al. (2007) attempted to date the upper gravel and sand unit (AG), obtaining an OSL age estimate of c. $61 \mathrm{ka}$, which is older than dates on the HBG below. This OSL age determination is probably spurious, reiterating the problems of dating ice proximal sediments expressed by Duller et al. (1995). The true age of the HBG remains enigmatic and awaits further research, but on present evidence the TL ages obtained from it support a Middle Devensian glaciation that affected at least the southern coast of the Moray Firth (Hall et al., 1995b; Hall and Connell, 2000; Merritt et al., 2003), as predicted by Hubbard et al. (2009).

A reticulate network of $S$ to $N / W$ to $E$ orientated glacial drainage channels are well displayed around the Tore of Troup and to the west of the Howe of Byth site (Figure 7) (Merritt and Peacock, 2000; fig. 22). These features formed mainly during the general westward retreat of combined Moray Firth and East Grampian ice (Bremner, 1934a) and locally cut into elongate ridges aligned with fs. 33, which are mainly controlled by the similarly orientated strike of the bedrock. Some channels probably have a long history. For example, in central Buchan, the bedrock cut channels that preserve sequences dating back possibly to MIS 8 at Kirkhill and Leys quarries have focussed meltwaters on a number of occasions, but which remain unfilled.

Lower Strath Spey and the Elgin Oscillation.

Surficial tills around Elgin and in lower Strath Spey are sandy and dominated by well-rounded clasts derived from ORS conglomerates cropping out to the west (Peacock et al., 1968; Aitken et al., 1979). The widespread upper diamict, the Tofthead Till of Hall et al. (1995a), has a strong WNW-ENE fabric (Table 4). These authors identified a younger sandy diamict locally, the Waterworks Till, which correlates with a local glacial readvance from the $\mathrm{W}$ or NW, possibly the Elgin Oscillation (EO) of Peacock et al. (1968). Neither of the above-mentioned tills were identified above the interglacial palaeosol at 
Teindland (Table 2 and 2) where another sandy diamict with complex glaciotectonic structures (Connell and Phillips, unpublished), the Woodside Diamicton, was formerly assigned to an Early Devensian glaciation (Hall, 2000).

None of the till units identified in lower Strath Spey can be correlated easily with fs.34, but they can be linked with glacial striae and other features described by Peacock et al. (1968) (Merritt et al., 2003, map 1). Most glacial drainage channels lying to the south of Elgin swing around towards the NE, suggesting that meltwater was flowing around a retreating ice lobe occupying the Moray Firth. This lobe was responsible for ponding the Spey Valley upstream of Fochabers, where laminated silts and clays were laid down in Glacial Lake Rothes (Fochabers) (GLR) (Bremner, 1934a), as at the Tofthead site (Table 2) (Connell, 2000a). Splendid southward-directed, deltaic foresets exposed in Glen Rothes were clearly deposited by meltwaters flowing from the margin of the lobe into the lake, whereas similarly well-preserved, northward dipping foresets were observed in Glen Rinnes, some $25 \mathrm{~km}$ to the south, where a delta formed at the margin of East Grampian ice.

Glacial Lake Rothes occupied ground that had been previously vacated by East Grampian ice, but the deltaic deposits preserved in Glen Rinnes show that ice flowing from the eastern Cairngorms remained to the south of the lake, possibly sufficiently active to have formed fs. 95 . Flowset 94 may also have formed at this time in the middle reaches of Strath Spey, although Hughes et al. (2014) speculate that it was created earlier (Table 1). West Highland-sourced ice (fs. 47) terminated in the vicinity of Grantown-on-Spey whilst the middle reaches of the Findhorn Valley remained blocked by ice (Merritt et al. (2013).

No definitive end-moraine has been assigned to the Elgin Oscillation, but Peacock et al. (1968) present evidence that GLR was still in existence during the EO, which they linked with the late S or SSE orientated scratches of two sets of cross-cutting striae recorded between Elgin and the coast (Merritt et al., 2003, map 1). The age of the EO may be estimated from the presence of glaciomarine muds of the Spynie Clay Formation (SCF), which underlies kettled, raised marine flats up to about $20 \mathrm{~m}$ OD between Elgin and Lossiemouth (Peacock et al., 1968; Peacock, 1999; Merritt et al., 2003). The muddy SCF has a low-diversity, high-arctic fauna similar to that in the Errol Clay Formation of eastern Scotland, which has yielded radiocarbon ages between 12.8 and $14.3 \mathrm{k}{ }^{14} \mathrm{C}$ a BP (c. 14-16k cal.BP) (Peacock, 1999; Hughes et al., 2016)). The SCF includes large dropstones and lenses of diamict indicating the presence of an ice front nearby (Peacock, 1999). Peacock et al. (1968) describe several sets of N-S orientated till ridges around Elgin formed at a westward retreating ice margin following the EO (Merritt et al., 2003, map 1). These ridges, together with others on the Black Isle, have been identified as de Geer moraines (Finlayson et al., 2007). Such features have not been recorded to the east of the Spey so their presence within the EO limits suggests that glaciological conditions may have changed following that event, associated with relatively high sea level. The Moray Firth ice stream probably became established at this time too, represented by fs. 6 (Hughes et al., 2014) (Figure 7). Finlayson et al. (2007) speculate that the de Geer moraines they identified around Elgin and on Tarbat Ness formed in the sea when it 
stood at c. $55 \mathrm{~m} \mathrm{OD}$, which is considerably higher than established by detailed sea level studies in the region (Merritt et al., 1995; Shennan et al., 2006). It is perhaps more likely that fresh water was ponded up to this level by NW Highland-sourced ice pinning against the coast to the east of the Spey.

\section{A review of critical parts of the offshore record}

In order to examine the event stratigraphy for NE Scotland in a wider context some critical parts of the offshore record must be considered, particularly the Norwegian Channel (NC) and the Witch Ground Basin (WGB) (Figure 1). Although firmly-based time-slice reconstructions of the last BIIS and SIS have been presented recently by Clark et al. (2012) and Hughes et al. (2015), these researchers found it difficult on present evidence to reconstruct the build-up and break-up of ice in the North Sea Basin, presenting alternative maximum and minimum scenarios. There was either complete disintegration in the North Sea Basin by 25 ka BP (more likely 22 ka BP), or two-stage deglaciation involving partial break-up of North Sea ice from the north, leaving a more persistent, low-profile ice dome over the central North Sea Basin.

The offshore record around NE Scotland and in the North Sea Basin has been reviewed by Holmes (1997), Merritt et al. (2003), Carr (2004), Stoker et al. (2011), Davies et al. (2011) and Graham et al. 2011). Thin-section micromorphology of borehole cores reveals that shell-bearing glaciomarine deposits in the central North Sea Basin have been glacially over-ridden on at least three occasions during the Devensian/Weichselian, but the episodes are poorly dated and the micromorphology of few borehole cores have been examined (Carr et al., 2006). Two advances (Ferder and Cape Shore) demonstrate confluence between the British and Scandinavian ice sheets during the early Weichselian and the Skjonghelleren Stadial (c.40 ka) respectively, whereas the final Bolders Bank episode (Late Weichselian) was regarded as more restricted with an ice-free corridor separating the two ice sheets (Sejrup et al., 2000; Carr, 2004).

Ice-rafted debris sourced from British volcanic rocks recovered from the Donegal/Barra Fan, off NW Scotland and Ireland, suggest that extensive regional glaciation with tidewater termini began at c. $45 \mathrm{ka}$ BP (Knutz et al., 2001; Peck et al., 2007). A broadly similar record was obtained from a core obtained from the adjacent Rockall Trough in which a continuous IRD flux is seen throughout MIS 2 and 3, with a pulse at c. 41 ka (Hibbert et al., 2010). These authors conclude that NW Britain was also extensively glaciated during MIS 4 from c. 70 ka onwards, with peaks in IRD at c.70.2 and $61.7 \mathrm{ka}$.

Southern Norway became extensively glaciated during MIS 3, but there is no firm evidence for glaciation of the North Sea Basin (Sejrup et al., 2009). Periods of ameliorated climate (including the Ålesund, Sandnes and Tolsta Interstadials) occurred between c. $39 \mathrm{ka}$ and $29 \mathrm{ka}$, alternating with limited glacial advances in western Norway (Sejrup et al., 2009). The northern part of the last BIIS built up towards the end of MIS 3, after c. 32k a BP (Whittington and Hall, 2002; Jacobi et al., 2009) at a time when Central Scotland remained largely ice free, judging from dates of $34.5 \mathrm{k}$ to $28.1 \mathrm{k}$ cal a BP obtained on 
glacially over-ridden organic deposits at Sourlie (Bos et al., 2004) and Balglass (Brown, 2007) (Figure 1). Ice expanded westwards to the shelf break shortly after 30k cal a BP (Wilson et al., 2002; Scourse et al., 2009; Bradwell and Stoker, 2015a; Bradwell and Stoker, 2015b et al.), it had reached at least as far as North Rona at 25-27 ka (Everest et al., 2013) and probably over-ran St Kilda, north-west of the Western Isles (Figure 1) at this time (Hiemstra et al., 2015). The Fennoscandian lce Sheet (FIS) first expanded southwards into Denmark through the Kattegat, between 29 and 26k cal a (Houmark-Nielsen and Kjaer, 2003). The peak in clastic sedimentation on the Barra Fan occurred at c. $27 \mathrm{ka}$ (Knutz et al., 2001), in agreement with a step-change increase in IRD flux at c. 27.4 ka recorded from the adjacent Rockall Trough (Hibbert et al., 2010). These dates coincide with the maximum extent of the north-eastern quadrant of the last BIIS deduced by Sejrup et al. (2009), Bradwell et al. (2008) and Hughes et al. (2016). The BIIS was confluent with Scandinavian ice in the central North Sea basin prior to $22 \mathrm{k}{ }^{14} \mathrm{C}$ a BP (Graham et al., 2011) or possibly as early as $27 \mathrm{k}$ cal a BP (Sejrup et al., 1994, 2014) when a major shelf-edge-parallel ice sheet became established from Cape Wrath to Norway (Sejrup et al., 2005). Ice appears to have been most extensive and thickest early in the development of the last BIIS, during the local LGM (Sejrup et al., 2009; Chiverrell and Thomas, 2010; Clark et al., 2012; Hughes et al., 2014, 2016) (Figure 1). Importantly, Scourse et al. (2009) report that the deep-sea ice-rafted detritus record from the continental slope adjacent to the last BIIS indicates that the ice sheet reached its maximum extent at Heinrich Event H2 (24 ka) (cf. Bond et al., 1993; Peck et al., 2007). Rapid retreat, initially characterised by peak ice-rafted debris (IRD) flux during Greenland Interstadial (GI) 2 at 23 ka was followed by readvance between 22 and $16 \mathrm{ka}$, embracing the global LGM. Major readjustments occurred during later stages (Hughes et al., 2014) when ice streams were established in the Moray Firth (Merritt et al., 1995), the Minch (Bradwell and Stoker, 2015) and the Firth of Tay (Golledge and Stoker, 2006).

Evidence for stages during the local LGM

Important new findings and dates have been published recently for the Norwegian Channel (NC) and the Witch Ground Basin (WGB). The Norwegian Channel Ice Stream (NCIS) may have operated within the Norwegian Channel throughout the last glacial cycle (Sejrup et al., 1995, 1998; Rise et al., 2004; Ottesen et al., 2005). However, pertinent information has been obtained from borehole MD99-2283 drilled on the western flank of the North Sea Fan (Lekens et al., 2009) (Figure 1). Based on bulk accumulation rate and concentration of ice-IRD it shows that glacial activity increased around 42k cal a BP at the time when the SIS expanded beyond the coast of Norway. Accumulation rates increased between 34k and 29.7k cal a BP and were highest between $25 \mathrm{k}$ and $19 \mathrm{k}$ cal a BP when the NCIS was particularly active and re-advanced on three occasions. A corollary is that the NCIS appears to have shut down between about 30k and $25 \mathrm{k}$ cal a BP, possibly because an ice divide became established across it between Shetland and Norway at this time. Indeed, a major shelf-edge-parallel ice divide lying across the Norwegian Channel was modelled numerically by Boulton et al. (1985) (Figure 9.1), constrained by these authors regional mapping of glacial features using satellite imagery. This period embraces the 
global sea-level minimum at 26k cal.a BP established by Peltier and Fairbanks (2006). Ordered layered expandable minerals (OLEM) identified in the core, probably derived from mudstones of Mesozoic age beneath the Moray Firth, were delivered to the fan between 24 and $22 \mathrm{k}$ cal a BP, during GI 2, following collapse of any such divide (Figure 9.3).

Although the positioning of an ice divide across the NC is difficult to reconcile with the role of the deep trough in concentrating flow along the west coast of Norway towards the shelf edge, its presence may explain some issues concerning the glacial records within the central and southern North Sea Basin. For example, several units of glacigenic sediment have palynological and minerogenic signatures suggesting that ice sourced in the Moray Firth flowed along the eastern coast of England and into the southern North Sea Basin during early stages of the last glaciation (Davies et al., 2011). Specifically, heavy mineral assemblages diagnostic of the Grampian Highlands and the north-east coast of Scotland, together with Late Jurassic palynomorphs sourced from the Moray Firth Basin or from northern England, have been identified in the Swarte Bank, Fisher and Bolders Bank formations of MIS 12, 6 and 2 respectively. A broadly similar suite has also been identified in the Horden Till of the Durham coast and the Skipsea Till of eastern Yorkshire, which were deposited by the North Sea lce Lobe of the last BIIS during the Dimlington Stadial (Davies et al., 2009, 2012). It has been difficult to reconcile this recurring south-eastward trajectory from the Moray Firth with ice sheet reconstructions placing low ice divides stretching across the central North Sea Basin between Scotland and Norway (Davies et al., 2011, fig.11; Busfield et al., 2015, fig.7). It is compatible, however, with the early south-east phase of flow of our event stratigraphy, which may have transported material from NE Scotland into the path of later ice streams flowing out of the Firth of Forth.

The Witch Ground Basin (WGB) (Figure 1) undoubtedly contains crucial evidence for understanding the glacial history of the north-eastern quadrant of the last BIIS and SIS (Sejrup et al., 1987, 1994, 2009; Hall et al., 2003; Graham et al., 2007, 2010). High-resolution seismic data, bathymetric records and dates on shells taken from sediment cores suggest that the basin was glaciated early in the last glaciation, between c.33k and $27 \mathrm{k}$ cal a BP (Sejrup et al., 2015) after which it became a shallow marine embayment with connections to the Atlantic Ocean east of Shetland and possibly the Norwegian Channel (Bradwell et al., 2008). We note, however, that the radiocarbon dates for shells in borehole 77/2 in the WGB span 9,000 years (Sejrup et al., 2015) and that reworking of shells from multiple ice-free periods would allow intervening periods of ice cover between $26.6 \mathrm{k}$ and $17.7 \mathrm{k} \mathrm{cal} \mathrm{a}$ BP (Sejrup et al., 2016).

Mega-scale glacial lineations (MSGL) imaged on 3D seismic datasets at the unconformable top of the uppermost glacigenic unit represent the signature of fast-flow within a grounded ice sheet (Graham et al., 2007; Graham et al., 2009; Graham et al., 2010). Their presence and general SE-NW orientation are compatible with a major ice stream (Witch Ground Ice Stream; WGIS) draining the northern North Sea Basin fed by coalescent British and 
Scandinavian ice sheets. Bradwell et al. (2008) interpret the former zone of confluence between the BIIS and FIS was positioned across the northern Orkney Islands with fast-flowing ice in the Orkney-Shetland Channel focusing sediment delivery north-westwards to the continental shelf edge. Flow towards the NW is supported by streamlined features, the Egersundbanken (Figure 9.6), lying some $50 \mathrm{~km}$ west of the Norwegian Channel, which reveal that grounded ice flowed north-westwards from the Baltic towards the WGB (Stalsberg et al., 2003). These glacial lineations indicate that the western margin of the NCIS was not always confined by the Norwegian Channel, especially if the northern sector of the trough becomes filled by ice flowing directly from inland (Figure 9.2). Furthermore, the Egersundbanken were not necessarily formed contemporaneously with the MSGL imaged in the WGB and could have formed during a subsequent event. An alternative scenario is illustrated in Figure 9.3 in which an ice stream flowing through the OrkneyShetland Channel scavenges ice that had previously built-up in the central North Sea Basin, creating the MSGL in the WGB during a purge event following the local LGM (see below). Bradwell et al. (2008) conclude that the WGIS operated earlier, between 31 and $25 \mathrm{k}$ cal a BP, but there are other difficulties with this scenario as Hall (2013) finds little or no support for the Shetland archipelago having been over-run by Scandinavian ice in the last glaciation. Moreover the WGB lineaments are also compatible with flow from the north-west (Graham et al., 2007).

Evidence for stages during and following the global LGM (23-21 ka)

Bradwell et al. (2008) speculate that a major glacial reorganisation was triggered by rapidly rising sea levels associated with $\mathrm{H} 2$, at c. 24 ka that resulted in a marine calving bay opening up between the BIIS and FIS along a north-south axis east of Shetland, followed by much of the northern North Sea Basin (Figure 9.4 and 9.5). Indeed, peak IRD flux coincident with this event is a feature of all records of the BIIS on its western margin (Scourse et al., 2009) and there is a convergence of evidence suggesting that the BIIS underwent a period of large-scale re-organization and overall reduction in ice volume of about $80 \%$ at about this time (Bowen et al., 2002; Chiverrell and Thomas, 2010; Finlayson et al., 2010; Clark et al., 2012; Hughes et al., 2014. Rising sea level alone may not have been the trigger as ice retreated from the shelf edge during warmer periods coinciding with influxes of Atlantic Water towards the Norwegian Sea (Brendryen et al., 2015) ), such as during Gl 2 at c. 23 ka. A warmer period is claimed to have occurred between $25 \mathrm{ka}$ and $20 \mathrm{ka}$ ('Trofors Interstadial') associated with significant glacial retreat in western Norway (Johnsen et al., 2012), but the geochronology is seriously questioned by Hughes et al. (2016).

Early deglaciation of the WGB is difficult to reconcile with peak sedimentation on the North Sea Fan by the NCIS at 25-19k cal a BP (Lekens et al., 2009) and with extension of the BIIS to maximum limits in Wales at 25.2 ka to 21.2 $\mathrm{ka}$, and in the Vale of York between $24.8 \mathrm{ka}$ and $21.8 \mathrm{ka}$ (Gibbard and Clark, 2011). Simulations indicate instead that this was a phase in which the BIIS extended to the North Atlantic shelf and was at intervals confluent with the FIS in the North Sea (Boulton and Hagdorn, 2006). Moray Firth ice was also simulated as confluent with Shetland ice after 23.7 ka (Hubbard et al., 2009). 
Although a scenario of a second maximum to the last ice sheet on northern Scotland appears to be in conflict with the onset of ice-free conditions in the WGB, Sejrup et al. (2016) now suggest that reworked marine shells in glaciomarine deposits may relate to periods of ice withdrawal from the WGB at $27-25.5 \mathrm{ka}$, after $18 \mathrm{ka}$, and during intervening periods.

Simulated solar-shaded renditions of the Olex bathymetric database now provide an unprecedented view of seafloor geomorphology from the continental shelf around the northern United Kingdom (www.olex.no) (Bradwell et al., 2008). In particular, the dataset reveals multiple ridges of distinct lobate moraines around Shetland and including the Bosies Bank, in the outer Moray Firth (Figure 1). The pattern of ice-marginal sea-bed features show unambiguously that a significant re-expansion of ice occurred over Orkney and Shetland (Bradwell et al., 2008; Clark et al., 2012; Bradwell and Stoker, 2015a) (Figure 1), when Scandinavian and Scottish ice possibly coalesced again in the northern North Sea Basin and adjusted to new quasistable marginal positions. The BIIS had readvanced off western Scotland by 19k cal a BP (Knutz et al., 2001) and the re-expansion peaked between c. 18.4 and 15.4k cal a BP (Brendryen et al., 2015). Sejrup et al. (2008) suggest that a shelf-edge parallel ice sheet was re-established from Shetland to Northern Ireland and Bradwell and Stoker (2015b) demonstrate that there was subsequent asymmetric retreat towards Orkney.

There is good geomorphological, stratigraphical and chronological evidence for three distinct ice-marginal positions (readvances) in the WGB. The oldest includes a glacial-fed debris wedge in the eastern part of the Basin that probably links with the Tampen Ridge (Figure 1), a lateral morainic feature formed at the western flank of the NCIS after c. $21 \mathrm{k}$ cal a BP (Sejrup et al., $1994,2000,2014)$. There were subsequently two glacial readvances of the BIIS from the north-west, Fladen 1 and Fladen 2 at c. 17.5k and 16.2k cal a BP respectively (Sejrup et al., 2015) (Figure 1 and 9.6 stages 8 and 9). The two Fladen readvances post-date the collapse of the NCIS, which occurred at between $19.5 \mathrm{k}$ to $18.5 \mathrm{k}$ cal a BP, based on radiocarbon age determinations on foraminifera and molluscs (Mangerud et al., 2013), or as early as 20.8 to $20.2 \mathrm{ka}$, based on cosmogenic ${ }^{10}$ Be exposure ages on glacial erratics on the island of Utsira (Figure 9.6) (Svendsen et al., 2015).

Uncertainty remains concerning the extent of the BIIS at the time the Tampen Ridge was formed. Was it formed at the marine-based margin of the NCIS, implying non-coalescence of the BIIS and FIS, or at a lateral shear margin between the ice stream and ice radiating out from a centre situated over Shetland (Hall 2013). Sejrup et al. (2000) conclude that the ridge resulted from re-advance of the NCIS during the Tampen Stadial (22-19k cal a BP), the time-span of the global LGM (Mix et al., 2001), when the adjacent Viking Bank area (Figure 1) was partially shallow high-arctic sea and dry land based on faunal palaeoenvironmental reconstruction and a recalibrated age of c.18.7k cal a BP on a mussel shell (Peacock, 1995; Hughes et al., 2016). However, this date would become at least 500 years younger if a more realistic marine reservoir age adjustment were made (JD Peacock, personal communication). Glacio-eustatic sea level is estimated to have been below - 
$140 \mathrm{~m}$ on the Viking Bank during the global LGM, suggesting that there was a forebulge of some $20 \mathrm{~m}$ (Peacock, 1995). The FIS also readvanced southwards into Denmark through the Kattegat, between $23 \mathrm{k}$ and $18 \mathrm{k}$ cal a BP (Houmark-Nielsen and Kjaer, 2003).

\section{A new event stratigraphy for NE Scotland}

Twelve stages in the evolution of the last BIIS in NE Scotland are recognised based on a parsimonious (ie. that no more causes or forces should be assumed than are necessary to account for the facts) interpretation of stratigraphic relationships, the subglacial bedform record and published dates at a number of critical sites, both onshore and offshore. The stages represent a likely minimum sequence of events. Stages 1 to 5 are established mainly from the lithostratigraphical record at a few key sites and are not yet securely dated. They probably include short-lived events that occurred during relatively long periods of maximum glaciation that left relatively little reported evidence in the region. Stages 6 to 12 may be linked more securely to retreat stages established from the terrestrial geomorphological record and sea-bed features by Clarke et al. (2012) (Figure 8). They are better age-constrained, but difficulties with the published geochronometry remain to be resolved.

Stage 1 [Middle Devensian]. Evidence from several sites indicates that ice advanced from the north-west across ground bordering the southern shore of the Moray Firth during the Middle Devensian. Luminescence ages from a gravel fan at Howe of Byth site suggest that ice reached the northern coast of Buchan between c. 45.4 and $37.8 \mathrm{ka}$ (Duller et al., 1995). A considerable accumulation of ice to the NW of the region resulted in a powerful, ESEdirected flow across ground rising to at least $500 \mathrm{~m}$ OD to the east of Inverness. Ice sourced from the Great Glen and NW Highlands laid down thick units of till against north-facing slopes of the Moray Firth and in the middle to lower reaches of the Nairn, Findhorn and Spey valleys. Published evidence from the Dalcharn, Moy, Clava, and Teindland localities (Figure 4) concludes that these sandy tills could have been deposited when ice advanced into NE Scotland after $37 \mathrm{ka}$ if the youngest TL age at Moy is accepted (Duller et al., 1995). However, an earlier Middle or Early Devensian age for at least some sandy till units remains probable on present evidence.

Stage 2. [c. 32-24 ka]. SE flow of ice from the Moray Firth also laid down dark grey, shelly tills across the coastal lowlands of Moray and Buchan. These tills with a rich Jurassic to early Cretaceous palynoflora (Riding, 1998; Riding, 2003; Riding and Stephenson, 2001) become thinner and patchy inland, where isolated glacial rafts commonly lie directly on bedrock or older glacigenic deposits. This suggests that subglacial boundary conditions changed from warm to cold-based as ice penetrated inland across central and eastern Buchan. Ice probably flowed both directly across and around the north of the Buchan peninsula, laying down dark shelly till in Logie-Buchan. AAR ratios (Miller et al., 1987) on derived shell fragments in glacigenic sediments, mostly from the King Edward site (SI Table 1, Figure 8c), indicate 
that the last BIIS advanced across Buchan in the latter part of the Middle Devensian (Peacock and Merritt, 2000a).

Although the evidence for SE flow is mainly based on till-provenance, tillfabric, erratic transport paths (Figure 3) and some SE-directed striae, it is likely that some elements assigned to fs.72, in eastern Buchan and possibly some ice-moulded rock features associated with fs. 92, SE of Forres, may have formed contemporaneously (Table 1). Ice was sufficiently thick to create SE-orientated striae on the NE flank of Bennachie at c. $335 \mathrm{~m}$ OD (Figure 7) and the SE-orientated flowset in Angus (Figure 7, fs. 7) invites correlation with this stage. It requires very thick ice cover over the eastern Grampians to drive ice across Strathmore and over the Sidlaw Hills, at up to 455 m OD.

We propose that a substantial shelf-edge parallel ice sheet became established during this stage, the local LGM. It covered Caithness (Hall and Riding, 2016), Orkney (Hall et al., 2016), Shetland (Hall 2013) and possibly linked with the SIS across the Norwegian Channel rather as modelled by Boulton et al. (1985) (Figure 9.1. Further expansion of ice flowing from a centre positioned over the Orkney-Shetland Platform and Scandinavia possibly buttressed ice flowing from the Moray Firth and the eastern Grampians, steering it south-eastwards across Buchan towards the southern NSB (Figure 9.2).

Stage 3 [c. 24 ka]. A major glacial reorganisation followed associated with dramatic thinning, but apparently not with widespread glacial retreat across NE Scotland. In eastern Buchan the direct superimposition of tills suggests that ice flow swung around to the ENE, towards the central NSB, creating fs. 36. Evidence is less secure to the west, but till provenance suggests that ice flow also generally swung around to the E or NE along the coast of the Moray Firth. There is no stratigraphical evidence for the hierarchical position of the northward trending fs.33 deduced by Hughes et al. (2014) (Table 1). It is suggested that some of the bedforms of fs. 33 are indeed cut by fs. 36 in eastern Buchan, but were created in an earlier glaciation. The bedforms of fs. 33 in western Buchan are relatively sparse, poorly developed and are generally aligned parallel to the northward strike of the bedrock, which forms most of these features. However, evidence of northward flow towards Orkney has been deduced by Hall et al. (2016), apparently following a significant period of ice sheet thinning and recession. The ice shed positioned across Caithness and Orkney during Stage 2 possibly migrated southwards towards Buchan and north-eastwards towards Shetland as a result of the establishment of an ice stream centred on the Orkney-Shetland Channel (Figure 9.3.1).

Stage 4 [c. 23 ka]. Thinning continued. At numerous localities on the high ground overlooking the inner Moray Firth sandy till laid down by the early ESE-directed flow of ice is directly overlain by till deposited by ice flowing NNE in general alignment with fs.34 (Merritt and Auton, 1993; Fletcher et al., 1996). Although contacts between the tills are generally sharp, no major unconformities, weathering profiles, palaeosols or organic deposits have been found that could be linked with a complete deglaciation. However, wedge- 
shaped pull-apart structures, hydrofractures, truncated gravel-filled channels, seams of glacitectonite and rip-up clasts of diamict suggest that ice-bed boundary conditions may have changed during the switch in flow direction.

Flowset 34 represents an extensive flowline directly towards the MFB from the Cairngorms and western Highlands via upper Strath Spey. A thick ice sheet is required to drive ice across the Spey-Findhorn divide at over $360 \mathrm{~m}$ OD

(Figure 4) and it follows that the Cairngorm tops remained fully glaciated at this time, as suggested by a limiting cosmogenic age of c. $21.3 \mathrm{ka}$ (Phillips et al., 2008). Hughes et al. (2014) link fs.34 with fs. 1 (Figure 7), concluding that ice flowed across the inner Moray Firth towards the NW Highlands. Hall and Riding (2016) and Hall et al. (2016) find no supporting evidence for this flow path. Instead, once ice reached the coast it was more likely to have been deflected sharply eastwards by ice flowing from the western and northwestern Highlands (Figure 9.3), as indicated at Dalcharn (Figure 4, SI Table 1) where ice first swung around to the east before flowing NNE (Walker et al., 1992).

The sparse, poorly developed bedforms of fs. 33 in western Buchan were possibly created after fs. 36 (Table 1), during northward drawdown of ice towards the MFB from an ice divide stretching from the Cairngorms towards Buchan (Figure 9.3). This hierarchy is supported by crossing striae recorded at two localities SSE of Banff, where eastward-directed striae are cut by northward or NNE-directed ones (Read, 1923; Merritt et al., 2003, map 3). It follows that eastern Buchan was protected beneath cold-based ice for there is no evidence there for contemporaneous northward flow.

The ice shed positioned between Buchan and Shetland possibly migrated farther to the east by the end of this stage, drawing ice north-westwards across the Witch Ground Basin (WGB) in accord with the flowsets identified there by Graham et al. (2007) and Bradwell et al. 2008 (Figure 9.3.2), but other scenarios are possible (Sejrup et al., 2016). The stage probably equates with the widespread dramatic thinning and drawdown of ice that affected at least the SW sector of the last BIIS during Greenland Interstadial (GI) 2 at c.23 ka (Scourse et al. 2009). Shetland retained an independent ice cap (Hall, 2013). Ice was drawn northwards from Strathmore towards Orkney at about this time, carrying chalk eroded from beneath the outer Moray Firth (Hall and Riding, submitted b).

Stage 5 [c. 22-19 ka]. Ice flowing through the MFB and Strathmore thickened and coalesced at the angle of Buchan, much as envisaged by Clapperton and Sugden (1977) (Figure 6a, 9.4). Ice flowed NNE along the coast from Strathmore as evidenced by red tills, glacial striae and subglacial landforms of flowset 51 . The former inland boundary of Strathmore ice can be traced NNE from the Ythan valley towards the mouth of the Den of Boddam, at about $80 \mathrm{~m}$ OD (Figure 6a), suggesting that there was ice occupying the central NSB at this time, preventing Strathmore ice from flowing directly offshore. The Wee Bankie Formation was laid down offshore (Stoker et al., 2011). Ice flowed towards, but probably did not reach the WGB. Central Buchan was mostly protected beneath cold-based ice. This stage is probably contemporaneous 
with the creation of the Tampen Ridge, at the western margin of the Norwegian Channel (Figure 1), during the Tampen Stadial of Sejrup et al. (2000) and the global LGM of Mix et al. (2001) between c. 22 and 19k cal a BP. The BIIS and SIS probably eventually re-coalesced when a shelf-edge parallel ice sheet regrew across Orkney and Shetland (Sejrup et al., 2014; Sejrup et al., 2016; Hall et al., 2016) (Figure 9.4). If so, the central NSB either became reoccupied by ice or an ice-locked, seasonally frozen lake.

Stage 6 [c. 22-19 ka]. A small ice-free enclave first opened up in eastern Buchan, occupied by Glacial Lake Ugie (GLU) at its $80 \mathrm{~m}$ level, in a window at the confluence of Strathmore, East Grampian and Moray Firth-sourced ice (Figure 6a). East Grampian ice slowly retreated westwards across Buchan, leaving a reticulate network of ice-marginal channels typical of cold-based ice margins (cf. Benn and Evans, 2010, fig. 8.38) (Figure 8b). A local glacial reorganisation followed general thinning of ice involving a further encroachment of Strathmore ice onshore between Aberdeen and Peterhead, up the valley of the River Ythan to the vicinity of Ellon, where it dammed a proglacial lake and formed arcuate end-moraines at the Cross-Stone site (SI Table 1, Figure 6b). The ice also advanced into the lower Ugie valley during this Logie-Buchan Readvance (LBR) damming the $50 \mathrm{~m}$ level of GLU in which thick sequences of laminated muds were deposited. The Logie-Buchan ice lobe subsequently decayed to form hummocky topography typical of ice stagnation. The distinctive suite of glacial erratics derived from the floor of the North Sea in the Kippet Hills Esker (Figure 6b, SI Table 1) suggests that ice still occupied the NSB to the east (Figure 9.4).

The $50 \mathrm{~m}$ GLU was dammed by a combination of Logie-Buchan and Moray Firth-sourced ice as no exits have been identified in the lower Ugie catchment and since the ground lies below $50 \mathrm{~m}$ OD towards both the north and east coasts. Deltas and glaciofluvial terrace gravels were laid down by meltwaters entering the lake from the west and south. These deposits experienced intense periglacial conditions during subsequent stages, testified by widespread preservation of tundra polygons and other cryogenic phenomena in the Ugie Valley, but attempts at OSL dating have proved inconclusive.

The valleys of the Don and Dee steered ice flowing eastwards from the Cairngorms parallel with fs.64. Flow became increasingly influenced by topography as the ice sheet thinned and its margin retreated westwards. Although East Grampian ice had retreated from at least the lower reaches of the Ythan and Ugie valleys during the LBR, the two ice masses abutted in the vicinity of Aberdeen where there is both stratigraphical and geomorphological evidence for limited eastward readvance, but no confining dates (see SI).

Stage 7 [c. 19 ka]. Strathmore and East Grampian ice continued to 'unzip' down the eastern coast. At first ponding occurred between the ice masses as they parted to the north of Aberdeen, where there was widespread glaciofluvial deposition as deltas and subaqueous fans (Figure 6c). Marine conditions apparently then ensued along the coast with relative sea level standing at about $30 \mathrm{~m}$ OD (Peacock, 1999). The presence of roughly E-W orientated linear ridges lying closely offshore (Figure $8 \mathrm{c}$ ), tentatively 
interpreted as de Geer moraines (Bradwell et al., 2008, fig. 5), suggest that the North Sea/Strathmore ice lobe calved into the sea that had entered from the NE (Figure 9.4). We deduce that ice must still have occupied the NSB to the east, buttressing the coastal ice lobe and stopping it from calving directly eastwards.

The 'unzipping' continued down the coast to Montrose, where Strathmore ice flowed directly seawards to create fs. 56, now unconstrained by ice lying offshore (Figure 9.5). Red marine clay was laid down at Lunan Bay (Figure 8) in open waters at c. $20.1-20.9 \mathrm{k}$ cal a BP when relative sea level stood at least $22 \mathrm{~m}$ OD following a possible minor readvance of Strathmore ice. However, these dates would become at least 500 years younger if a more realistic marine reservoir age adjustment were made (JD Peacock, personal communication). Shennan et al. (2006) suggest that the area only became ice-free after c.17 ka. The Lunan Bay Clay (LBC) clay is capped by glacial outwash that includes thin beds of till (Rice, 1959), suggesting that Strathmore ice did not readvance far beyond the present coastline, where there is another cluster of possible de Geer moraines (Figure $8 \mathrm{~d}$ ). The recessional retreat limits shown in Figure 8 support Peacock et al. (2007) in that the LBC cannot be correlated with any glacial readvance at Perth as suggested by McCabe et al. (2007). The LBC probably correlates with the St Abbs Formation offshore (Gatliff et al., 1994), which should drape over, and not underlie the ridge features if they are correctly re-interpreted as de Geer moraines.

Stage 8 [18-17.5 ka]. This stage is correlated with the Fladen 1 Readvance (17.5k cal. a BP) identified in the WGB (Clark et al., 2012; Sejrup et al., 2015) (Figure 9.6.8). The BIIS and Fennoscandian Ice Sheet (FIS) had separated by this time as the Viking Bank (Figure 1) had become ice-free by c. $18.3 \mathrm{ka}$ (Peacock, 1995; Hughes et al., 2016). The contemporaneous position of ice within the Norwegian Channel is unclear, but had possibly retreated to the south of Utsira (Svendsen et al., 2015) (Figure 9.6).

Stage 9 [17.5-16.2ka]. There is stratigraphical evidence around Peterhead and Fraserburgh, supported by till provenance and striae, for a limited readvance of ice southwards from the MFB (Peacock, 2000b) (Figure 6b). This ice mass ice subsequently shrank and receded actively across the northeastern tip of Buchan, where fs. 100 was created in association with similarly orientated moraine ridges and glaciofluvial outwash (Figure 6c). Deep channels offshore (Figure 1) may have been partly created at this time. A huge ice lobe now occupied the MFB, fed from the NW through to the SE. Sea-bed features can be traced from Peterhead to the northern tip of Shetland via the Bosies Bank (Clark et al., 2012) (Figure 8 and 9.6.9), where the Fladen 2 Readvance moraine has been dated at 16.2k cal. a BP (Sejrup et al., 2015).

Stage 10 [c. 16 ka]. Evidence from St Fergus, north of Peterhead, suggests that the margin of the Moray Firth ice lobe terminated in the sea at c. $12 \mathrm{~m}$ OD, before a minor readvance created the St Fergus Push Moraine (SFPM) (Figure 6c). This feature includes faulted, tilted and deformed masses of bedded marine silt and sand formed by ice push from the east or NE. The 
absence of contemporary late-glacial marine deposits south of Peterhead suggests that the sea had retreated from the area owing to rapid glacioisostatic rebound. Radiocarbon dates on marine bivalves in the deformed raised glaciomarine deposits at St Fergus suggest that the readvance occurred sometime after $17.5 \mathrm{k}$ cal a BP (later if a marine reservoir adjustment of greater than 400 years is made). The SFPM has been linked tentatively with sea-bed features off the northern tip of Orkney (Clark et al., 2012) (Figure 8 and 9.6.10) and it possibly correlates with a minor readvance that deposited the Wick Till in Caithness (Hall and Riding, 2016).

Stage 11 [c. 16-15 ka]. During subsequent retreat the southern margin of the Moray Firth ice lobe was pinned along the Banffshire coast where proglacial lakes, ice-marginal drainage channels and swathes of glaciofluvial outwash were formed (Figure 6c). Evidence of minor readvances of the Moray Firth ice lobe against the coast have been reported, notably to the west of Banff. A limit that swings around from the vicinity of Banff to the north-eastern tip of Caithness has been identified tentatively by Clark et al. (2012) (Figure 8 and 9.6.11). The pattern of sea-bed features off the northern coast (Figure 8) suggests that renewed ice accumulation occurred across the OrkneyShetland Platform after Caithness had possibly become an ice-free corridor (Bradwell and Stoker, 2015b), but Hall et al. (2016) find evidence only of SE retreat across Orkney.

This stage possibly witnessed a general thickening of ice across the eastern Grampians when ice encroached northwards towards the MFB, depositing the so-called 'Northern Drift', which is associated with little till, but numerous blocks of locally-derived Huntly/Knock Gabbro (Read, 1923) (Figure 4). The re-advance probably created fs. 35 , a suite of subdued subglacial bedforms of NNW orientation around Durn Hill (Figure 7 and 8).

Stage 12 [c.15 ka]. The configuration of retreat limits around Elgin (Figure 8) indicate that ice re-occupied the lower reaches of Strath Spey, supporting the 'Elgin Oscillation' (EO) proposed by Peacock et al. (1968). Ice at the coast ponded lakes in an area previously vacated by East Grampian ice. Deltaic deposits preserved in Glen Rothes and Glen Rinnes indicate that meltwater entered the lakes from the north and south respectively. Ice flowing from the eastern Cairngorms probably formed fs. 95 at this time to the south of Glen Rinnes, possibly coevally with fs. 94 in the middle reaches of Strath Spey (Table 1). Ice sourced in the western Highlands flowed via upper Strath Spey (fs. 47), terminating in the vicinity of Grantown-on-Spey, whilst the middle reaches of the Findhorn remained blocked by ice.

Sets of N-S orientated linear ridges around Elgin (Merritt et al., 2003, map1) subsequently formed at the westward retreating margin of ice that created fs. 6 . These ridges, together with others on the Black Isle, have been identified as de Geer moraines at an elevation of c. $55 \mathrm{~m}$ OD (Finlayson et al., 2007). These ridges most likely formed in water ponded behind ice that continued to block drainage out into the Moray Firth. As similar features have not been recorded to the east of the Spey their presence within the EO glacial limits 
suggests that glaciological conditions may have changed following that event, associated with the initiation of the Moray Firth Ice Stream (fs. 6). The age of the EO may be estimated circumstantially to have occurred at c. $15 \mathrm{ka}$.

\section{Discussion}

Glaciological inversion from the subglacial bedform record led Hughes et al. (2014) to conclude that the last BIIS had two modes of flow-pattern geometry. An early, thick (relative to topography) integrated ice sheet reaching the shelf edge with a simple ice-divide structure and a later, much thinner mode of ice sheet comprising multiple dispersion centres and a more complex flow structure. The two modes of ice flow geometry compare favourably with forward transient modelling experiments of the last BIIS reported by Boulton and Hagdorn (2006) and Hubbard et al. (2009), which produce very dynamic ice sheets with numerous 'binge-purge', advance - retreat cycles dominated by ice streaming. However, the flow set models and ice sheet simulations have until now not been compared closely with the lithostratigraphical records of NE Scotland, considered here, Caithness (Hall and Riding, 2016) and Orkney (Hall et al., 2011; Hall et al., 2016).

The experiments predict multiple advances and retreats of Grampian ice across NE Scotland, but this is not substantiated by the stratigraphical record. Although there is evidence in the form of stacked till and gravel sequences for multiple phases in Caithness (Hall and Riding, 2016) relatively fewer units have been recorded across Buchan, probably because ice was mainly coldbased and relatively inactive for long periods of time, as predicted by the simulations. The experiments build-up substantial thicknesses of ice across the NW Highlands, Orkney and Shetland that feed into the Moray Firth at $35.3,33.6$ and $32.3 \mathrm{ka}$, which is not at variance with the stratigraphical record of those areas (Hall and Riding, 2016: Hall et al., 2016) (Stage 1). However, they do not satisfactorily accommodate the extensive, early, south-easterly flow of ice deduced to have crossed Buchan from the MFB during the local LGM (Figure 9. 2). This discrepancy probably results partially from the impracticality of these modelling experiments to consider interactions with Scandinavian ice, which may significantly affect reconstructions of the NE quadrant of the BIIS. It may be pertinent, however, that although Hubbard et al. (2009) conclude that the maximum build-up of ice occurred between 27.5 and $18.5 \mathrm{ka}$, they could not discount two 'noteworthy' experiments using their optimal subset of data that yielded maximum ice conditions between 29 and $24 \mathrm{ka}$.

Some conclusions of Hubbard et al. (2009) are particularly relevant, notably that the coldest periods result in the slow growth of cold-based, high-viscosity ice that advances with high aspect ratios across NE Scotland primarily by viscous creep, accompanied by very localised zones of warm-based flow. 'Binge phases' such as these consequently result in very limited, patchy subglacial erosion and till deposition, and are probably conducive to the transport and preservation of glacial rafts, which are common in coastal 
regions of Scotland (Merritt et al., 2014). The binge phases build up large ice volume, which is the essential precursor to subsequent purge-advance phases. These relatively short-lived events, characterised by streaming, wetbased ice with a lower aspect ratio tend to dominate the geomorphological legacy through formation of extensive flowsets and to be more fully represented in the stratigraphical record through deposition of deforming-bed till.

Hubbard et al. (2009) find that the periods of maximum areal extent of the BIIS and ice-streaming do not occur during the coldest periods, rather to the transitions to warmer conditions irrespective of relative sea level changes. They predict very rapid deglaciation between 18 and $15 \mathrm{ka}$ accompanied by the release of vast amounts of meltwater, which is supported by the occurrence of swathes of glacial outwash deposits in the region and evidence for ice-marginal lakes. However, they do not predict the Fladen readvances into the WGB identified by Sejrup et al. (2015).

There is general agreement that following earlier expansions during MIS 4 and 3 the western margin of the BIIS reached the shelf-edge by c. $29 \mathrm{ka}$ and that the ice sheet reached its maximum size by Heinrich $(\mathrm{H}) 2$ (c. $24 \mathrm{ka}$ ) at the end of the local LGM (Scourse et al., 2009; Chiverrell and Thomas, 2010). The sequence and chronology of events in the NSB is uncertain and clearly awaits further research to resolve (Clarke et al. 2012; Hughes et al., 2016). The sequence there includes glacially-overridden sediments (Carr et al., 2006) likely to embrace complex structural relationships, rafts of partially reworked material and pockets of subglacially deposited sand and gravel containing reworked shells, making correct interpretation of radiocarbon dates, palynology and provenance studies difficult from boreholes. On balance, a marine embayment probably opened up twice in the central NSB. Firstly during GI 2 and again shortly following the global LGM when the sea reached as far south as Lunan Bay by an adjusted age of c. 20k cal a BP. This dating is not easy to accommodate with cosmogenic isotope exposure ages as late as $17.5 \pm 2.6 \mathrm{ka}$ for the deglaciation of ground above $200 \mathrm{~m}$ in Buchan (Phillips et al., 2008; Ballantyne, 2010), although adoption of alternative production rates to those determined by Ballantyne (2010) could change the cosmogenic age quoted above to $19.1 \pm 2.5 \mathrm{ka}$ (Hughes et al., 2016).

\section{Conclusions}

- The proposed 12-stage event stratigraphy for the last glaciation of NE Scotland broadly accords with recent reconstructions of the last BIIS, which was dynamic and reached its greatest thickness between 29 and 24 ka during the local LGM. At least three 'binge-purge' cycles are identified.

- The last ice sheet to cover NE Scotland witnessed abrupt changes in ice flow direction and geometry, but its peripheral location in respect both to accumulation centres to the west and the shelf-edge margin 
probably resulted in large sectors remaining cold-based for long periods, dampening its response to rapid changes in climate.

- The pattern of retreat across NE Scotland suggests that re-expansions of ice occurred leading to local readvances.

- Events inferred from the lithostratigraphy are not always represented by flowsets, and some flowsets are not only time-transgressive, but developed during different flow events, making recognition of spatial and age relationships problematic when based on cross-cutting relationships alone.

- The integration of lithostratigraphy with the subglacial bedform record provides a powerful tool for the reconstruction of the last BIIS in its north-eastern section, but more detailed till lithostratigraphy, provenance studies and dating is required, especially in eastern Buchan, where varved sediments are likely to occur, and offshore.

- The review strengthens concerns regarding the published geochronometry, particularly the integration of ages produced by different dating methods and of adjustments and recalibrations that have been made to them.

\section{Acknowledgements}

We are grateful to Dr Anna Hughes for her comments on earlier versions of this manuscript and for providing clipped subsets of her UK-wide interpretations. AMH thanks the Carnegie Trust for the Universities of Scotland for supporting fieldwork in northern Scotland. Some of ERCs work was undertaken when in receipt of an NERC Studentship during 1977-1980 for which he is most grateful and he would like to thank Dr Al Gemmell for his help and interest since he first worked in NE Scotland. We all thank Dr Jim Riding (BGS, Keyworth, Nottingham) for his detailed palynological analyses of tills and Dr Douglas Peacock for information, advice and support over many years. Craig Woodward is thanked for cartographic support. JWM publishes as an Honorary Research Associate with the permission of the Executive Director, BGS (NERC).

\section{REFERENCES}

Aitken A M, Merritt J W, Shaw A J. 1979. The sand and gravel resources of the country around Garmouth, Grampian Region: Description of 1:25 000 resource Sheet NJ 36. Mineral Assessment Report 41. Institute of Geological Sciences: London.

Aitken J F. 1995. Lithofacies and depositional history of a Late Devensian icecontact deltaic complex, northeast Scotland. Sedimentary Geology 99: 11130.

Aitken J F. 1998. Sedimentology of Late Devensian glaciofluvial outwash in the Don Valley, Grampian Region. Scottish Journal of Geology 34: 97-117. 
Auton CA. 1993. Dalcharn. In Quaternary of Scotland: Geological Conservation Review, Gordon J E Sutherland, D G (eds). Chapman and Hall: London; 154-159.

Auton C A, Crofts R G. 1986. The sand and gravel resources of the country around Aberdeen, Grampian Region: Description of 1:25 000 resource sheets NJ71, 80, 81 and 91, with parts of NJ61, 90 and 92, and with parts of NO89 and 99. Mineral Assessment Report 146. British Geological Survey: Edinburgh.

Auton C A, Gordon J E, Merritt J W, Walker M J C. 2000. The glacial and interstadial sediments at the Burn of Benholm, Kincardineshire: evidence for onshore pre-Devensian ice movement in northeast Scotland. Journal of Quaternary Science 15: 141-156.

Ballantyne C K. 2010. Extent and deglacial chronology of the last British-Irish Ice Sheet: Implications of exposure dating using cosmogenic isotopes. Journal of Quaternary Science 25: 515-534.

Ballantyne C K, Harris C. 1994. The Periglaciation of Great Britain. Cambridge University Press: Cambridge.

Ballantyne C K, 5 others. 1998. High-resolution reconstruction of the last ice sheet in NW Scotland. Terra Nova 10: 63-67.

Bateman MD, Evans DJA, Buckland PC, Connell ER, Friend RJ, Hartmann D, Moxon H, Fairburn WA, Panagiotakopulu E, Ashurst RA 2015. Last glacial dynamics of the Vale of York and North Sea lobes of the British and Irish Ice Sheet. Proceedings of the Geologists' Association 126: 712-730.

Benn DI, Evans DJA. 2010. Glaciers and glaciation. Second Edition. Hodder: London.

Bloodworth A J. 1990. Clay mineralogy of Quaternary sediments from the Dalcharn Interglacial site. In Beauly to Nairn: Field Guide, Auton C A, Firth C R, Merritt J W (eds). Quaternary Research Association: Cambridge: 60-61.

Boardman J. 1985. The Troutbeck Palaeosol, Cumbria, England. In Soils and Quaternary landscape evolution, Boardman J (ed). Wiley: London; 231-260.

Bond G, 6 others. 1993. Correlation between climate records from North Atlantic sediments and Greenland ice. Nature 365: 143-147.

Bos J A A, Dickson J H, Coope G R, Jardine W G. 2004. Flora, fauna and climate of Scotland during the Weichselian Middle Pleniglacial - palynological, macrofossil and coleopteran investigations. Palaeogeography, Palaeoclimatology, Palaeoecology 204: 65-100. 
Boulton G S, Jones A S, Clayton K M, Kenning M J. 1977. A British ice-sheet model and patterns of glacial erosion and deposition in Britain. In British Quaternary studies: recent advances, Shotton F W (ed). Claredon Press: Oxford; 231-246.

Boulton G S, Smith G D, Jones A S, Newsome J. 1985. Glacial geology and glaciology of the last mid-latitude ice sheets. Journal of the Geological Society of London 142: 447-474.

Boulton G S, Peacock J D, Sutherland D G. 1991. Quaternary. In Geology of Scotland (3rd edition), Craig G Y (ed). The Geological Society: London; 503543.

Boulton G S, Hagdorn M. 2006. Glaciology of the British Isles Ice Sheet during the last glacial cycle: form, flow, streams and lobes. Quaternary Science Reviews 25: 3359-3390.

Bowen D Q. 1989. The last interglacial-glacial cycle in the British Isles. Quaternary International 3 pt.3: 41-47.

Bowen D Q, Rose J, McCabe A M, Sutherland D G. 1986. Correlation of Quaternary glaciations in England, Ireland, Scotland and Wales. In Quaternary Glaciations in the Northern Hemisphere, Sibrava V, Bowen D Q, and Richmond G M (eds). Quaternary Science Reviews 5: 299-340.

Bowen D Q, Sykes G A. 1988. Correlation of marine events and glaciations on the northeast Atlantic margin. Philosophical Transactions of the Royal Society of London, Vol. B 318: 619-635.

Bowen DQ, Phillips FM, McCabe AM, Knutz, PC, Sykes G.A. 2002. New data for the last glacial maximum in Great Britain and Ireland. Quaternary Science Reviews 21: 89-101.

Bradwell T, Stoker M.S. 2015a. Submarine sediment and landform record of a palaeo-ice stream within the British-Irish Ice Sheet. Boreas 44: 255-276.

Bradwell T, Stoker M.S. 2015b. Asymmetric ice-sheet retreat pattern around northern Scotland revealed by marine geophysical surveys. Earth and Environmental Science Transactions of the Royal Society of Edinburgh 2014:1-26

Bradwell T, Stoker M, Golledge N, Wilson C, Merritt JW, Long D, Everest J, Hestvik OB, Stevenson A, Hubbard A, Finlayson A, Mathers, H. 2008. The northern sector of the last British Ice Sheet: Maximum extent and demise. Earth Science Reviews 88: 207-226.

Bremner A. 1916. Problems in the glacial geology of northeast Scotland and some fresh facts bearing on them. Transactions of the Edinburgh Geological Society 10: 334-347. 
Bremner A. 1917. Low-level kettle-holes in and near Aberdeen. Transactions of the Edinburgh Geological Society 11: 23-24.

Bremner A. 1920a. Limits of valley glaciation in the basin of the Dee.

Transactions of the Edinburgh Geological Society 11: 61-68.

Bremner A. 1920b. The glacial geology of the Stonehaven District. Transactions of the Edinburgh Geological Society 11:25-41.

Bremner A. 1928. Further problems in the glacial geology of north-eastern Scotland. Transactions of the Edinburgh Geological Society 12: 147-164.

Bremner A. 1931. The valley glaciation in the district round Dinnet, Cambus o'May and Ballater. The Deeside Field 5: 15-24.

Bremner A. 1934a. The glaciation of Moray and ice movements in the north of Scotland. Transactions of the Edinburgh Geological Society 13: 17-56.

Bremner A. 1934b. Meltwater drainage channels and other glacial phenomena of the Highland Border Belt from Cortachy to the Bervie Water. Transactions of the Edinburgh Geological Society 13: 174-175.

Bremner A. 1936. The glaciation of Glenesk. Transactions of the Edinburgh Geological Society 13: 378-382.

Bremner A. 1943. The glacial epoch in the north-east. In The Book of Buchan (Jubilee Volume), Tocher J F (ed). P Scrogie Ltd \& Aberdeen University Press: Aberdeen; 10-30.

Brendryen J, Haflidason H, Rise L, Chand S, Vanneste M, Longva O, L'Heureux J S and Forsberg CF. 2015. Ice sheet dynamics on the LofotenVesteralen shelf, north Norway, from Late MIS-3 to Heinrich Stadial 1. Quaternary Science Reviews 119: 136-156.

British Geological Survey 1997 Fortrose, Scotland Sheet 87E. Solid and Drift. 1:50 000. British Geological Survey: Keyworth, Nottingham.

Brown EJ, Rose J, Coope RG, Lowe JJ. 2007. An MIS 3 age organic deposit from Balglass Burn, central Scotland: palaeoenvironmental significance and implications for the timing of the onset of the LGM ice sheet in the vicinity of the British Isles. Journal of Quaternary Science 22: 295-308.

Brown IM. 1993. Pattern of deglaciation of the last (Late Devensian) Scottish ice sheet: evidence from ice-marginal deposits in the Dee valley, north-east Scotland. Journal of Quaternary Science 8: 235-250.

Brown IM. 1994. Former glacial lakes in the Dee valley: origin, drainage and significance. Scottish Journal of Geology 30: 147-158. 
Busfield ME, Lee JR, Riding JB, Zalasiewicz J, Lee SV. 2015. Pleistocene till provenance in east Yorkshire: reconstructing ice flow of the British North Sea Lobe. Proceedings of the Geologists' Association 126: 86-99.

Campbell R. 1934. On the occurrence of shelly boulder clay and interglacial deposits in Kincardineshire. Transactions of the Edinburgh Geological Society 13: $176-182$.

Carr SJ. 2004. The North Sea Basin. In Quaternary Glaciations Extent and Chronology. Part 1: Europe, Ehlers J, Gibbard PL (eds). Elsevier: Amsterdam; 261-270.

Carr SJ, Holmes R, Van Der Meer JJM, Rose J. 2006. The Last Glacial Maximum in the North Sea Basin: micromorphological evidence of extensive glaciation. Journal of Quaternary Science 21: 131 -153.

Charlesworth JK. 1957. The Quaternary Era, 2 Vols. Edward Arnold: London.

Chiverrell, RC, Thomas GSP. 2010. Extent and timing of the Last Glacial Maximum (LGM) in Great Britain and Ireland: a review. Journal of Quaternary Science 25: 535-549.

Clapperton CM. 1997. Greenland Ice Cores and North Atlantic Sediments: Implications for the Last Glaciation in Scotland. In: Reflections on the Ice Age in Scotland, Gordon JE (ed). Scottish Natural Heritage: Edinburgh; 45-58.

Clapperton CM, Sugden DE. 1977. The Late Devensian glaciation of northeast Scotland. In Studies in the Scottish Lateglacial environment, Gray JM, Lowe JJ (eds). Pergamon Press: Oxford, 1-13.

Clark CD, Evans DJA, Khatwa A, Bradwell T, Jordan CJ, Marsh SH, Mitchell WA and Bateman MD. 2004. BRITICE: map and GIS database of landforms and features related to the last British Ice Sheet. Boreas 33: 359-375.

Clark, C.D., Gibbard, P.L. and Rose, J. 2004. Pleistocene Glacial Limits in England, Scotland and Wales. In. Ehlers. J. and Gibbard, P.L. (Eds.), Quaternary Glaciations: Extent and Chronology, Elsevier, 47-82.

Clark CD, Hughes ALC, Greenwood L, Jordan C, Sejrup HP. 2012. Pattern and timing of retreat of the last British-Irish Ice Sheet. Quaternary Science Reviews 44: 112-146.

Clayton KM. 1974. Zones of glacial erosion. Institute of British Geographers Special Publication 7: 163-176.

Connell ER. 1984. Kirkhill Quarry. Deposits above the upper palaeosol. In Buchan Field Guide, Hall AM (ed). Quaternary Research Association: Cambridge, 64-69. 
Connell ER. 2000a Tofthead, Fochabers. In The Quaternary of the Banffshire coast and Buchan: Field Guide, Merritt JW, Connell ER, Bridgland DR (eds). Quaternary Research Association: London, 38-39.

Connell ER, Edwards KJ, Hall AM. 1982. Evidence for two pre-Flandrian palaeosols in Buchan, Scotland. Nature 297: 570-572.

Connell ER, Hall, AM, Shaw D and Riley LA. 1985. Palynology and significance of radiocarbon- dated organic materials from Cruden Bay Brick Pit, Grampian Region, Scotland. Quaternary Newsletter 47: 19-25.

Connell ER, Hall AM. 1987. The periglacial stratigraphy of Buchan. In Periglacial Processes and Landforms in Britain and Ireland, Boardman J (ed). Cambridge University Press: Cambridge; 277-285.

Connell ER, Hall AM. 2000. Leys and Kirkhill quarries. In The Quaternary of the Banffshire coast and Buchan: Field Guide, Merritt JW, Connell ER, Bridgland DR (eds). Quaternary Research Association: London, 65-67.

Cumming GA, Bate PA. 1933. The Lower Cretaceous erratics of the Fraserburgh district, Aberdeenshire. Geological Magazine 70:397-413.

Davies BJ, Roberts DH, Ó Cofaigh C, Bridgland DR, Riding JB, Phillips ER and Teasdale, DA. 2009. Interlobe ice sheet dynamics during the Last Glacial Maximum at Whitburn Bay, County Durham, England. Boreas 38: 555-578.

Davies BJ, Roberts DH, Bridgland DR, O' Cofaich C, Riding JB. 2011. Provenance and depositional environments of Quaternary sediments from the western North Sea Basin. Journal of Quaternary Science 26: 59-75.

Davies, BJ, Roberts DH, Bridgland DR, Ó Cofaigh C, Riding JB, Demarki B, Penkman, KEH and Pawley SM. 2012. Timing and depositional environments of Middle Pleistocene glaciation on northern England: new evidence from Warren House Gill, County Durham. Quaternary Science Reviews 44: 180217.

Duller GAT, Wintle AF, Hall AM. 1995. Luminescence dating and its application to key pre-Late Devensian sites in Scotland. Quaternary Science Reviews 14: 495-519.

Ehlers J, Wingfield R. 1991. The extension of the Late Weichselian/Late Devensian ice sheets in the North Sea Basin. Journal of Quaternary Science 6: 313-326.

Evans D, Chesher JA, Deegan CE, Fannin NGT. 1981 The offshore geology of Scotland in relation to the IGS shallow drilling programme, 1970-1978.

Report of the Institute of Geological Sciences 81/12. 
Evans DJA, Clark CD, Mitchell WA. 2005. The last British ice sheet: a review of the evidence utilized in the compilation of the glacial map of Britain. EarthScience Reviews 70: 253-312.

Everest JD, Bradwell T, Stoker MS, Dewey S. 2013. New age constraints for the maximum extent of the last British-Irish lce Sheet (NW Sector). Journal of Quaternary Science 28: 2-7.

Fabel D, Ballantyne CK, Xu S. 2012. Trimlines, blockfields, mountain-top erratics and the vertical dimensions of the last British-Irish lce Sheet in NW Scotland. Quaternary Science Reviews 55: 91-102.

Finlayson A, Bradwell T, Golledge N R, Merritt JW. 2007. Morphology and significance of transverse ridges (De Geer moraines) adjacent to the Moray Firth, NE Scotland. Scottish Geographical Journal 123: 257-270.

Finlayson A, Merritt JW, Browne M, Merritt JE, McMillan A, Whitbread K. 2010. Ice sheet advance, dynamics and decay configurations: evidence from west central Scotland. Quaternary Science Reviews 29: 969-988.

Fitzpatrick EA. 1958. An introduction to the periglacial geomorphology of Scotland. Scottish Geographical Magazine 74: 28-36.

Fitzpatrick EA. 1972. The principal Tertiary and Pleistocene events in northeast Scotland. In North-East Scotland Geographical Essays, Clapperton CM (ed). Department of Geography, University of Aberdeen: Aberdeen; 1-4

Fitzpatrick EA. 1987. Periglacial features in the soils of north east Scotland. In Periglacial processes and landforms in Britain and Ireland, Boardman $\mathrm{J}(\mathrm{ed})$. Cambridge University Press: Cambridge; 153-162.

Fletcher TP, Auton CA, Highton AJ, Merritt JW, Robertson S, Rollin KE. 1996. Geology of the Fortrose and eastern Inverness District. Memoir of the British Geological Survey, Sheet 84W (Scotland). British Geological Survey: Keyworth, Nottingham.

Flinn D. 1967. Ice front in the North Sea. Nature: 215, 1151 - 1154.

Gatliff RW, 11 others. 1994. United Kingdom offshore regional report: the geology of the central North Sea. HMSO for the British Geological Survey: London.

Geikie J. 1894. The Great Ice Age and its Relation to the Antiquity of Man, 3rd edition. Edward Stanford: London.

Gemmell AMD, Ralston IBM. 1984. Some recent discoveries of ice-wedge cast networks in north-east Scotland. Scottish Journal of Geology 20: 115118. 
Gemmell AMD, Murray AS, Connell ER. 2007. Devensian glacial events in Buchan (NE Scotland): a progress report on new OSL dates and their implications. Quaternary Geochronology 2: 237-242.

Gibbard PL, Clark CD. 2011. Pleistocene glacial limits in Great Britain. In Quaternary glaciations: extent and chronology: a closer look, Ehlers J, Gibbard PL, Hughes PD (eds), Elsevier: Amsterdam; 75-94.

Glentworth R, Mitchell WA, Mitchell BD. 1964. The red glacial drift deposits of north-east Scotland. Clay Minerals Bulletin 5: 373-381.

Golledge NR, Stoker MS. 2006. A palaeo-ice stream of the British Ice Sheet in eastern Scotland. Boreas 35: 231-243.

Gordon JE. 1993a Clava. In Quaternary of Scotland. Geological Conservation Review Series: 6, Gordon JE, Sutherland DG (eds). Chapman and Hall: London; 165-170.

Gordon JE. 1993b. Boyne Quarry. In Quaternary of Scotland. Geological Conservation Review Series: 6, Gordon JE, Sutherland DG (eds). Chapman and Hall: London; 233-236

Gordon JE, 1993c. Kippet Hills. In Quaternary of Scotland. Geological Conservation Review Series: 6, Gordon JE, Sutherland DG (eds). Chapman and Hall: London; 242-245.

Gordon JE, Sutherland DG (eds). 1993. Quaternary of Scotland. Geological Conservation Review Series: 6. Chapman and Hall: London.

Graham AGC, Lonergan L, Stoker MS. 2007. Evidence for Late Pleistocene ice stream activity in the Witch Ground Basin, central North Sea, from 3D seismic reflection data. Quaternary Science Reviews 26: 627-643.

Graham AGC, Lonergan L, Stoker MS. 2009. Seafloor glacial features reveal the extent and decay of the last British Ice Sheet, east of Scotland. Journal of Quaternary Science 24: 117-138.

Graham AGC, Lonergan L, Stoker MS. 2010: Depositional environments and chronology of Late Weichselian glaciation and deglaciation in the central North Sea. Boreas 39: 471-491.

Graham AG, Stoker MS, Lonergan L, Bradwell T, Stewart MA. 2011. The Pleistocene glaciations of the North Sea basin. In: Quaternary glaciations: extent and chronology: a closer look, Ehlers J, Gibbard PL, Hughes PD (eds). Elsevier; 261-278.

Greenwood SL, Clark CD. 2009a. Reconstructing the last Irish Ice Sheet 1: changing flow geometries and ice flow dynamics deciphered from the glacial landform record. Quaternary Science Reviews 28: 3085-3100. 
Hall, A M. 1984. Buchan Field Guide. Quaternary Research Association: Cambridge.

Hall AM. 1985. Cenozoic weathering covers in Buchan, Scotland and their significance. Nature 315: 392-395.

Hall AM. 1986. Deep weathering patterns in north-east Scotland and their geomorphological significance. Zeitschrift für Geomorphologie NF 30: 407422.

Hall AM. 1987. Weathering and relief development in Buchan, Scotland. Part II. In International Geomorphology 1986, Gardiner V (ed). (John Wiley:

Chichester; 991-1005.

Hall AM. 1991. Pre-Quaternary landscape evolution in the Scottish Highlands. Transactions of the Royal Society of Edinburgh: Earth Sciences 8: 1-26.

Hall AM. 1997. Quaternary Stratigraphy: the Terrestrial Record. In Reflections on the Ice Age in Scotland, Gordon JE (ed). Scottish Association of Geography Teachers and Scottish Natural Heritage: Glasgow; 59-71

Hall, AM. 2000. The Teindland Interglacial site. In The Quaternary of the Banffshire coast and Buchan: Field Guide, Merritt JW, Connell ER, Bridgland DR (eds). Quaternary Research Association: London; 34-37.

Hall AM, 2013. The last glaciation of Shetland: local ice cap or invasive ice sheet? Norwegian Journal of Geology 93: 229-242.

Hall AM, Sugden DE. 1987. Limited modification of mid-latitude landscapes by ice sheets. Earth Surface Processes and Landforms 12: 531-542.

Hall AM, Jarvis J. 1989. A preliminary report on the Late Devensian glaciomarine deposits around St Fergus, Grampian Region. Quaternary Newsletter 59: 5-7.

Hall AM, Bent AJA. 1990. The limits of the last British Ice Sheet in northern Scotland and the adjacent shelf. Quaternary Newsletter 61: 2-12.

Hall AM, Connell ER. 1991. The glacial deposits of Buchan, northeast Scotland. In Glacial Deposits in Great Britain and Ireland, Ehlers J, Gibbard PL, Rose J (eds). Balkema: Rotterdam; 129-136.

Hall AM, Jarvis J. 1993a. Kirkhill. In Quaternary of Scotland. Geological Conservation Review Series: 6, Gordon JE, Sutherland DG (eds). Chapman and Hall: London; 225-230.

Hall, A M. and Jarvis, J. 1993b. Bellscamphie. In Quaternary of Scotland. Geological Conservation Review Series: 6, Gordon JE, Sutherland DG (eds). Chapman and Hall: London; 230-233. 
Hall AM, Jarvis J. 1995. A multiple till sequence near Ellon, Grampian Region: T. F. Jamieson's 'indigo boulder clay' re-examined. Scottish Journal of Geology 31: 53-59.

Hall AM, Whittington G, Duller GAT, Jarvis J. 1995a. Late Pleistocene environments in lower Strathspey, Scotland. Transactions of the Royal Society of Edinburgh: Earth Sciences 85: 253-273.

Hall AM, Duller G, Jarvis J, Wintle AG. 1995b. Middle Devensian ice-proximal gravels at Howe of Byth, Grampian Region. Scottish Journal of Geology 31: 61-64.

Hall AM, Connell ER. 2000. Howe of Byth Quarry. In The Quaternary of the Banffshire coast and Buchan: Field Guide, Merritt JW, Connell ER, Bridgland DR (eds). Quaternary Research Association: London; 72-74.

Hall AM, Peacock JD. 2000. King Edward. In The Quaternary of the Banffshire coast and Buchan: Field Guide, Merritt JW, Connell ER, Bridgland DR (eds). Quaternary Research Association: London; 43-45.

Hall AM, Peacock JD, Connell ER. 2003. New data for the Last Glacial Maximum in Great Britain and Ireland: comments on the paper by Bowen et al. (2002). Quaternary Science Reviews 22: 1551-1554.

Hall AM, Auton, CA, Michie, U McL, Pearson SG, Riding JB. 2011. Switching flow patterns within the last ice sheet in northern Scotland. Scottish Journal of Geology 47: 157-167.

Hall AM, Gilg HA, Fallick AE, Merritt JW. 2015. Kaolins in gravels and saprolites in north-east Scotland: evidence from stable $\mathrm{H}$ and $\mathrm{O}$ isotopes for Palaeocene-Miocene deep weathering. Palaeogeography, Palaeoclimatology and Palaeoecology, 424: 6-16.

Hall AM, Riding JB. 2016 in press. The last glaciation in Caithness, Scotland: revised till stratigraphy and ice flow paths indicate multiple ice flow stages. Scottish Journal of Geology.

Hall AM, Riding JB, Brown, JF. 2016, in press. The last glaciation in Orkney, Scotland: glacial stratigraphy, event sequence and flow paths. Scottish Journal of Geology.

Hart R. 1941. Soil studies in relation to geology in an area in north-east Scotland. Part 1. The mineralogy of the soil parent materials. Journal of Agricultural Science 31: 438-447.

Heijnis H, van der Plicht J. 1992. Uranium/thorium dating of late Pleistocene peat deposits in NW Europe, uranium/thorium isotope systematics and opensystem behavior of peat layers. Chemical Geology 94: 161-171. 
Hiemstra JF, Shakesby RA, Vieli A. 2015. Late Quaternary glaciation in the Hebrides sector of the continental shelf: was St Kilda overrun by the BritishIrish Ice Sheet? Boreas 44: 178-196.

Hibbert FD, Austin WEN, Leng MJ, Gatliff RW. 2010. British Ice Sheet dynamics inferred from North Atlantic ice-rafted debris records spanning the last 175,000 years. Journal of Quaternary Science 25: 461 - 482.

Holmes R. 1997. Quaternary stratigraphy: the offshore record. In Reflections on the Ice Age in Scotland, Gordon JE (ed). Scottish Association of Geography Teachers and Scottish Natural Heritage: Glasgow; 72-94.

Horne J. 1923. The geology of the Lower Findhorn and Lower Strath Nairn. Memoir of the Geological Survey of Great Britain, Sheet 84 and part of 94 (Scotland).

Horne J, Hinxman LW. 1914. The geology of the country around Beauly and Inverness. Memoir of the Geological Survey of Great Britain, Sheet 83 (Scotland).

Houmark-Nielsen M, Kjaer KH. 2003. Southwest Scandinavia, 40-15 kyr BP: palaeogeography and environmental change. Journal of Quaternary Science 18: 769-786.

Hubbard A, Bradwell T, Golledge N, Hall A, Patton H, Sugden, D, Cooper R, Stoker M. 2009: Dynamic cycles, ice streams and their impact on the extent, chronology and deglaciation of the British-Irish ice sheet. Quaternary Science Reviews 28: 758-776.

Hughes, ALC, Clark CD, Jordan CJ. 2010. Subglacial bedforms of the last British Ice Sheet. Journal of Maps v2010: 543-563.

Hughes ALC, Greenwood SL, Clark CD. 2011. Dating constraints on the last British-Irish Ice Sheet: a map and database. Journal of Maps v2011: 156-183.

Hughes ALC, Clark CD, Jordan CJ. 2014. Flow-pattern evolution of the last British Ice Sheet. Quaternary Science Reviews 89: 148-168.

Hughes ALC, Gyllencreutz R, Lohne, ØS, Mangerud J, Svendsen JI. 2016. The last Eurasian ice sheets - a chronological database and time-slice reconstruction, DATED-1. Boreas 45: 1-45.

Jacobi RM, Rose J, McLeod A and Higham TFC. 2009. Revised radiocarbon ages on woolly rhinoceros (Coelodonta antiquitatis) from west central Scotland: significance for timing the extinction of woolly rhinoceros in Britain and the onset of the LGM in central Scotland. Quaternary Science Reviews 28: $2551-2556$.

Jamieson TF. 1858. On the Pleistocene deposits of Aberdeenshire. Quarterly Journal of the Geological Society of London 14: 509-532. 
Jamieson TF. 1882a. On the Red Clay of the Aberdeenshire coast and the direction of ice-movement in that quarter. Quarterly Journal of the Geological Society of London 38: 160-177.

Jamieson TF. 1882b. On the crag shells of Aberdeenshire and the gravel beds containing them. Quarterly Journal of the Geological Society of London 38: 145-159.

Jamieson TF. 1906. The glacial period in Aberdeenshire and the southern border of the Moray Firth. Quarterly Journal of the Geological Society of London 62: 13-39.

Johnsen TF, Olsen L, Murray A. 2012. OSL ages in central Norway support a MIS 2 interstadial (25-20 ka) and a dynamic Scandinavian ice sheet. Quaternary Science Reviews 44: 96-111.

Johnson H, Richards PC, Long D, Graham CC, 1993. United Kingdon Offshore regional report: the geology of the northern North Sea. HMSO: London.

Kleman J, 1994. Preservation of landforms under ice sheets and ice caps. Geomorphology 9: 19-32.

Knutz PC, Austin WEN, Jones EJW. 2001. Millenial-scale depositional cycles related to British Ice Sheet variability and North Atlantic palaeocirculation since 45 kyr BP, Barra Fan, UK margin. Palaeoceanography 16: 53-64.

Lambeck K. 1995. Late Devensian and Holocene shorelines of the British Isles and North Sea from models of glacio-hydro-isostatic rebound. Journal of the Geological Society of London 152: 437-448.

Lekens WAH, Haflidason H, Sejrup HP, Nygard A, Richter T, Vogt C, Frederichs T. 2009. Sedimentation history of the North Sea Margin during the last 150 ka. Quaternary Science Reviews 28: 469-483.

Mackie W. 1901. Some notes on the distribution of erratics over eastern Moray. Transactions of the Edinburgh Geological Society 8: 91-97.

Mangerud J, 6 others. 1981. A Middle Weichselian ice-free period in Western Norway: the Ålesund interstadial. Boreas 10: 447-462.

Mangerud J, Goehring BM, Lohne OS, Svendsen JI, Gyllencreutz R. 2013. Collapse of marine-based outlet glaciers from the Scandinavian Ice Sheet. Quaternary Science Reviews 67: 8-16.

McCabe AM, Clark PU, Smith DE, Dunlop P. 2007. A revised model for the last deglaciation of eastern Scotland. Journal of the Geological Society of London 164: 313-316. 
McLean F. 1977. The glacial sediments of a part of Aberdeenshire. Unpublished PhD thesis, University of Aberdeen.

McMillan AA, Aitken AM. 1981. The sand and gravel resources of the country west of Peterhead, Grampian Region. Description of 1:25 000 sheet NK 04 and parts of NJ 94, 95 and NK 05, 14 and 15. Mineral Assessment Report of the Institute of Geological Sciences 58.

McMillan AA, Hamblin RJO, Merritt JW. 2011. A lithostratigraphical framework for onshore Quaternary and Neogene (Tertiary) superficial deposits of Great Britain and the Isle of Man. British Geological Survey Research Report, RR/10/03. British Geological Survey: Keyworth, Nottingham.

McMillan AA, Merritt JW. 2012. A new Quaternary and Neogene lithostratigraphical framework for Great Britain and the Isle of Man. Proceedings of the Geologists' Association 123: 679-691.

Merritt, J W. 1981. The sand and gravel resources of the country around Ellon, Grampian Region. Description of 1:25 000 resource sheets NJ93 with parts of NJ82, 83 and 92, and NK03 and parts of NK02 and 13. Mineral Assessment Report of the Institute of Geological Sciences 76.

Merritt, J.W. 1990: The Allt Odhar Interstadial Site, Moy, Inverness-shire: Lithostratigraphy. In Beauly to Nairn: Field Guide, Auton CA, Firth CR, Merritt JW (eds). Quaternary Research Association: Cambridge; 62-69.

Merritt JW. 1992. The high-level marine shell-bearing deposits of Clava, Inverness-shire, and their origin as glacial rafts. Quaternary Science Reviews 11: 759-779.

Merritt JW. 1993. Allt Odhar. In Quaternary of Scotland. Geological Conservation Review Series: 6, Gordon JE, Sutherland DG (eds). Chapman and Hall: London; 159-164.

Merritt JW, Auton CA. 1990. The Dalcharn Interglacial Site, near Cawdor, Nairnshire: Lithostratigraphy. In: Beauly to Nairn: Field Guide, Auton CA, Firth CR, Merritt JW (eds). Quaternary Research Association: Cambridge; 41-54.

Merritt, JW, Auton CA. 1993. Notes on exposures and natural sections in drift deposits occurring on Geological Sheet 84W (Fortrose), SE of Inverness, Scotland. British Geological Survey Technical Report WA/93/28R. British Geological Survey: Edinburgh.

Merritt JW, Connell ER. 2000a. Oldmill Quarry. In The Quaternary of the Banffshire coast and Buchan: Field Guide, Merritt JW, Connell ER, Bridgland DR (eds). Quaternary Research Association: London; 68-71. 
Merritt JW, Connell ER. 2000b. The Ardglassie rafts. In The Quaternary of the Banffshire coast and Buchan: Field Guide, Merritt JW, Connell ER, Bridgland DR (eds). Quaternary Research Association: London; 75-78.

Merritt JW, Peacock JP. 2000. Glacial meltwater channels in Banffshire and Buchan. In The Quaternary of the Banffshire coast and Buchan: Field Guide, Merritt JW, Connell ER, Bridgland DR (eds). Quaternary Research Association: London; 46-48.

Merritt JW, Auton CA, Firth CR. 1995. Ice-proximal glaciomarine sedimentation and sea-level change in the Inverness area, Scotland: a review of the deglaciation of a major ice stream of the British Late Devensian ice sheet. Quaternary Science Reviews 14 289-329.

Merritt JW, Connell ER, Bridgland DR (eds). 2000. The Quaternary of the Banffshire coast and Buchan: Field Guide. Quaternary Research Association, London.

Merritt JW, Auton CA, Connell ER, Hall AM, Peacock JD, 2003. Cainozoic geology and landscape evolution of north-east Scotland. British Geological Survey, Edinburgh.

Merritt JW, Auton CA, Boston CM, Everest JD, Merritt JE. 2013. An overview of main Late Devensian glaciation of the Central Grampian Highlands. In: Boston, CM, Lukas S, Merritt JW (eds). The Quaternary of the Monadhliath Mountains and the Great Glen: Field Guide. Quaternary Research Association, London; 25-40.

Merritt JW, Akhurst MC, Wilkinson IP, Riding JB, Phillips ER, Smith RA, Finlayson A, Dean MT. 2014. The Late Pleistocene Afton Lodge Clay Formation, Ayrshire, Scotland: Evidence for Early to Middle Devensian climatic changes and Late Devensian onshore ice flow and rafting from the Firth of Clyde. Proceedings of the Geologists' Association 125: 195-214.

Miller GH, Sejrup HP, Mangerud J, Andersen BG. 1983. Amino acid ratios in Quaternary molluscs and foraminifera from western Norway: Aminostratigraphy and paleotemperature estimates. Boreas 12: 107-124.

Miller GH, seven others. 1987. Racemization-derived late Devensian temperature reduction in Scotland. Nature 326: 593-595.

Milne J. 1892. Drift rocks in Buchan. Transactions of the Buchan Field Club 2: 181-198.

Mix AC, Bard E, Schneider R. 2001. Environmental processes of the Ice Age: land, oceans, glaciers (EPILOG). Quaternary Science Reviews 20: 627-657.

Munro M. 1986. Geology of the country around Aberdeen. Memoir of the British Geological Survey, Sheet 77 (Scotland). 
Murdoch WM. 1977. The glaciation and deglaciation of south east Aberdeenshire. Unpublished PhD thesis, University of Aberdeen.

Nesje A, Sejrup HP. 1988. Late Weichselian/Late Devensian ice sheets in the North Sea and adjacent areas. Boreas 17: 371-384.

Ottesen D, Dowdeswell JA, Rise, L. 2005. Submarine landforms and the reconstruction of fast-flowing ice streams within a large Quaternary ice sheet: the $2500-\mathrm{km}$-long Norwegian-Svalbard margin $\left(57^{\circ}-80^{\circ} \mathrm{N}\right)$. Geological Society of America Bulletin 117: 1033-1050.

Owens B, Marshall J (eds). 1978. Micropalaeontological biostratigraphy of samples from around the coasts of Scotland. Report of the Institute of Geological Sciences, No. 78/20.

Peach BN, Horne J. 1893. On the occurrence of shelly boulder clay in North Ronaldsay, Orkney. Transactions of the Edinburgh Geological Society 6: 309313.

Peacock JD. 1971. A re-interpretation of the coastal deposits of Banffshire and their place in the late-Glacial history of NE Scotland. Bulletin of the Geological Survey of Great Britain 37: 81-89.

Peacock JD, 1975. Scottish Late- and Post-glacial marine deposits. 45 - 48 in Quaternary Studies in North East Scotland. Gemmell AMD (editor). (Aberdeen: University of Aberdeen).

Peacock JD. 1984. Errolston. In Buchan Field Guide. Hall AM (ed). Quaternary Research Association: Cambridge; 108-109.

Peacock JD. 1995. Late Devensian to Early Holocene palaeoenvironmental changes in the Viking Bank area, northern North Sea. Quaternary Science Reviews 14: 1029-1042.

Peacock JD. 1997. Was there a readvance of the British ice sheet into the North Sea between $15 \mathrm{ka}$ and 14 ka BP? Quaternary Newsletter 81: 1-8.

Peacock JD. 1999. The pre-Windermere Interstadial (Late Devensian) raised marine strata of eastern Scotland and their macrofauna: a review. Quaternary Science Reviews 18: 1655-1679.

Peacock JD. 2000a. A comment on the faunas from the Whitehills Glacigenic Formation. In The Quaternary of the Banffshire coast and Buchan: Field Guide, Merritt JW, Connell ER, Bridgland DR (eds). Quaternary Research Association: London; 44-45.

Peacock JD. 2000b. A glaciated pavement and crossing striations between Fraserburgh and Rattray Head. In The Quaternary of the Banffshire coast and Buchan: Field Guide, Merritt JW, Connell ER, Bridgland DR (eds). Quaternary Research Association: London; 56. 
Peacock JD, Berridge NG, Harris AL, May F. 1968. The geology of the Elgin district. Memoir of the Geological Survey, Sheet 95 (Scotland).

Peacock JD, Merritt JW. 1997. Glacigenic rafting at Castle Hill, Gardenstown, and its significance for the glacial history of northern Banffshire, Scotland. Journal of Quaternary Science 12: 283-294.

Peacock JD, Connell ER 2000. Glacial lakes in the valleys of the North Ugie and South Ugie. In The Quaternary of the Banffshire coast and Buchan: Field Guide, Merritt JW, Connell ER, Bridgland DR (eds). Quaternary Research Association: London, 49-52.

Peacock JD, Merritt JW. 2000a. Glacial deposits at the Boyne Limestone Quarry, Portsoy, and the late-Quaternary history of coastal Banffshire. Journal of Quaternary Science 15: 543-555.

Peacock JD, Merritt JW. 2000b. Boyne Limestone Quarry. In The Quaternary of the Banffshire coast and Buchan: Field Guide, Merritt JW, Connell ER, Bridgland DR (eds). Quaternary Research Association: London; 25-32.

Peacock JD, Merritt JW. 2000c. Castle Hill, Gardenstown. In The Quaternary of the Banffshire coast and Buchan: Field Guide, Merritt JW, Connell ER, Bridgland DR (eds). Quaternary Research Association: London; 40-42.

Peacock JD, Merritt JW. 2000d. Exposures in the Blackhills Sand and Gravel Formation and related deposits. In The Quaternary of the Banffshire coast and Buchan: Field Guide, Merritt JW, Connell ER, Bridgland DR (eds). Quaternary Research Association: London; 53-55.

Peacock JD, Hall AH, Connell ER. 2000. St Fergus. In The Quaternary of the Banffshire coast and Buchan: Field Guide, Merritt JW, Connell ER, Bridgland DR (eds). Quaternary Research Association: London; 62-64.

Peacock JD, Armstrong M, Browne MAE, Stoker MS. 2007. Discussion on a revised model for the last deglaciation of eastern Scotland. Journal of the Geological Society of London, 164, 1261-1263.

Peck VL, Hall IR, Zahn R, Grousset F, Hemming SR. 2007. The relationship of Heinrich events and their European precursors over the past $60 \mathrm{ka}$ BP: a multi-proxy ice-rafted debris provenance study in the North East Atlantic. Quaternary Science Reviews 26: 862-875.

Peltier WR, Fairbanks RG. 2006. Global glacial ice volume and Last Glacial Maximum duration from an extended Barbados sea level record. Quaternary Science Reviews 25: 3322-3337.

Phillips ER, Merritt JW. 2008. Evidence for multiphase water-escape during rafting of shelly marine sediments at Clava, Inverness-shire, NE Scotland. Quaternary Science Reviews 27; 988-1011. 
Phillips WM, Hall AM, Ballantyne CK, Binnie S, Kubik PK, Freeman S. 2008. Extent of the last ice sheet in northern Scotland tested with cosmogenic ${ }^{10} \mathrm{Be}$ exposure ages. Journal of Quaternary Science 23: 101-107.

Rea BR, Gemmell AMD. 2006 Scottish Landform Example 40: The Buchan Gravels Formation: A remnant deposit of a palaeo-landscape. Scottish Geographical Journal 125: 182-194.

Read HH. 1923. The geology of the country around Banff, Huntly and Turriff (Lower Banffshire and North-west Aberdeenshire). Memoir of the Geological Survey, Scotland, Sheets 86 and 96.

Read HH, Bremner A, Campbell R, Gibb AW. 1923. Records of the occurrence of boulders of Norwegian rocks in Aberdeenshire and Banffshire. Transactions of the Edinburgh Geological Society 11: 230-231.

Rice RJ. 1959. The glacial deposits of the Lunan and Brothock valleys in south-eastern Angus. Transactions of the Edinburgh Geological Society 17: 241-259.

Riding JB. 1998. A Palynological Investigation of a Quaternary Sample from Boyne Bay, Banffshire). British Geological Survey Technical Report $W H / 98 / 17 R$. British Geological Survey: Edinburgh.

Riding JB. 2003. A palynological study of the glacigenic sediments of the Aberdeen/Buchan area, Scotland. British Geological Survey Internal Report IR/03/001. British Geological Survey: Keyworth, Nottingham.

Riding JB, Stephenson MH. 2001. A palynological study of tills from Aberdeenshire, Scotland. British Geological Survey Internal Report IR/01/172. British Geological Survey: Keyworth, Nottingham.

Rise L, Olesen O, Rokoengen K, Ottersen D, Riis F. 2004. Mid-Pleistocene drainage pattern in the Norwegian Channel imaged by 3D seismic. Quaternary Science Reviews 23: 2323-2335.

Scourse, JD, Haapaniemi, Al, Colmenero-Hidalgo, E, Peck, VL, Hall, IR, Austin, WEN, Knutz, PC, Zahn, R, 2009. Growth, dynamics and deglaciation of the last British-Irish ice sheet: the deep-sea ice-rafted detritus record. Quaternary Science Reviews 28: 3066-3084.

Sejrup HP, 9 others. 1987. Quaternary stratigraphy of the Fladen area, central North Sea: a multidisciplinary study. Journal of Quaternary Science 2: 35-58.

Sejrup HP, 7 others. 1995. Quaternary of the Norwegian Channel; paleoceanography and glaciation history. Norsk Geologisk Tidsskrift 75: 6587. 
Sejrup HP, 6 others. 1994. Late Weichselian glaciation history of the northern North Sea. Boreas 23: 1-13.

Sejrup HP, 5 others. 1998. The Jaeren area: a border zone of the Norwegian Channel Ice Stream. Quaternary Science Reviews 17: 801-812.

Sejrup HP, 5 others. 2000. Quaternary glaciations in southern Fennoscandia: evidence from southwestern Norway and the northern North Sea region. Quaternary Science Reviews 19: 667-685.

Sejrup H P, 13 others. 2003. Configuration, history, and impact of the Norwegian Channel Ice Stream. Boreas 32: 18-36.

Sejrup H P, Hjelstuen B O, Dahlgren K I T, Haflidason H, Kuijpers A, Nygard A, Praeg D, Stoker M S, Vorren T O. 2005. Pleistocene glacial history of the NW European continental margin. Marine and Petroleum Geology 22: 11111129.

Sejrup HP, Nygard A, Hall AM, Haflidason H. 2009. Middle and Late Weichselian (Devensian) glaciation history of south-western Norway, North Sea and eastern UK. Quaternary Science Reviews 28: 370-380.

Sejrup HP, Hjelstuen BO, Nygard A, Haflidason H, Martal I. 2015. Late Devensian ice-marginal features in the central North Sea - processes and chronology. Boreas 44: 1-13.

Sejrup HP, Clark CD, Hjelstuen BO. 2016. Rapid ice sheet retreat triggered by ice stream debuttressing: evidence from the North Sea. Geology. Data Repository item 2016112 doi: 10.1130/G376552.1

Shennan I, Bradley S, Milne G, Brooks A, Bassett S, Hamilton S. 2006. Relative sea-level changes, glacial isostatic modelling and ice-sheet reconstructions from the British Isles since the Last Glacial Maximum. Journal of Quaternary Science 21: 585-599.

Simpson S. 1948. The glacial deposits of Tullos and Bay of Nigg, Aberdeen. Transactions of the Royal Society of Edinburgh 61: 687-687.

Simpson S. 1955. A re-interpretation of the drifts of north-east Scotland. Transactions of the Edinburgh Geological Society 16: 189-199.

Sissons JB. 1967. The Evolution of Scotland's Scenery. Oliver \& Boyd: Edinburgh \& London.

Sissons JB. 1976. The Geomorphology of the British Isles: Scotland. Methuen: London.

Stalsberg K, Larsen E, Ottesen D, Sejrup HP. 2003. Middle to Late Weichselian Norwegian Channel Ice Stream deposits and morphology on 
Jaeren, south-western Norwy and the eastern North Sea area. Boreas 32: 149-166.

Stoker MS, Holmes R. 1991. Submarine end-moraines as indicators of Pleistocene ice limits of NW Britain. Journal of the Geological Society of London 148: 431-434.

Stoker MS, Balsom PS, Long D, Tappin DR. 2011. An overview of the lithostratigraphical framework for the Quaternary deposits on the United Kingdom continental shelf. British Geological Survey Research Report $R R / 11 / 03$.

Sutherland DG. 1984. The Quaternary deposits and landforms of Scotland and the neighbouring shelves: a review. Quaternary Science Reviews 3: 157254.

Sutherland DG. 1993. Teindland Quarry. In Quaternary of Scotland. Geological Conservation Review Series: 6, Gordon JE, Sutherland DG (eds). Chapman and Hall: London; 236-240.

Sutherland DG, Gordon JE. 1993. The Quaternary in Scotland. In Quaternary of Scotland. Geological Conservation Review Series: 6, Gordon JE, Sutherland DG (eds). Chapman and Hall: London; 13-47.

Svendsen JI, Briner JP, Mangerud J, Young NE. 2015. Early break-up of the Norwegian Channel Ice Stream during the Last Glacial Maximum. Quaternary Science Reviews 107: 231-242.

Synge FM. 1956. The glaciation of north-east Scotland. Scottish Geographical Magazine 72: 129-143.

Synge FM. 1963. The Quaternary succession round Aberdeen, north-east Scotland. In Report on the 6th International Congress on the Quaternary, Warsaw, 1961. International Union for Quaternary Research: Lodz; 353-361.

Thomas GSP. 1984. Sedimentation of a sub-aqueous esker-delta at Strabathie, Aberdeenshire. Scottish Journal of Geology 20: 9-20.

Thomas GSP, Connell R J. 1985. Iceberg drop, dump, and grounding structures from Pleistocene glacio-lacustrine sediments, Scotland. Journal of Sedimentary Petrology 55: 243-249.

Trewin NH (ed). 2002. The Geology of Scotland. The Geological Society: London.

Van Amerongen JC. 1976. The study of two soils in an area near Mintlaw, North-East Scotland. Unpublished MSc thesis, University of Aberdeen.

Walker MJC, Merritt JW, Auton CA, Coope GR, Field MH, Heijnis H, Taylor BJ. 1992. Allt Odhar and Dalcharn: two pre-Late Devensian (Late 
Weichselian) sites in northern Scotland. Journal of Quaternary Science 7: 6986.

Whittington G. 1990. The Dalcharn Interglacial site: Results of pollen analysis. In Beauly to Nairn: Field Guide, Auton CA, Firth CR, Merritt JW (eds). Quaternary Research Association: Cambridge 57-59.

Whittington G. 1994. Bruckenthalia spiculfolia (Salisb.) Reichenb. (Ericaceae) in the Late Quaternary of western Europe. Quaternary Science Reviews 13: 761-768.

Whittington G, 6 others. 1998. Devensian organic interstadial deposits and ice sheet extent in Buchan, Scotland. Journal of Quaternary Science 13: 309-324.

Whittingham G, Hall AM. 2002. The Tolsa Interstadial, Scotland: Correlation with D-O cycles Gi-8 to Gi-5? Quaternary Science Reviews 21: 901-915.

Wilson JSG. 1886. North-east Aberdeenshire with detached portions of Banffshire. Memoirs of the Geological Survey, Scotland, Sheet 87.

Wilson LJ, Austin WEN, Jansen E. 2002. The Last British Ice Sheet: growth, maximum extent and deglaciation. Polar Research 21: 243-250.

Wright WB. 1914. The Quaternary Ice Age. Macmillan: New York. 
Table 1. Hierarchy and correlation of flow-sets in NE Scotland; top after Hughes et al. (2014); bottom as suggested here with asterisks denoting change in deduced flow direction. Size of box denotes uncertainty in age or time-transgressive nature of flowset.

\begin{tabular}{|c|c|c|c|c|c|c|c|c|}
\hline 6 & 47,96 & 92 & \multirow[b]{2}{*}{35} & 100 & & \multirow[b]{2}{*}{64} & \multirow[t]{2}{*}{56} & \\
\hline 3 & 3 & & & \multirow[t]{2}{*}{36} & & & & \\
\hline & \multicolumn{3}{|c|}{33} & & \multirow[t]{2}{*}{72} & & \multirow[t]{2}{*}{51} & \multirow[b]{2}{*}{7} \\
\hline & & & & & & 93 & & \\
\hline
\end{tabular}

\begin{tabular}{|c|c|c|c|c|c|c|c|}
\hline 6 & 47,96 & & & & & & \\
\hline \multirow[t]{6}{*}{3} & 95 & & & & & & \\
\hline & 94 & & & 100 & \multirow[b]{2}{*}{64,93} & & 56 \\
\hline & & & $35 *$ & & & & \\
\hline & & \multirow[t]{3}{*}{33} & & & & & 51 \\
\hline & 34 & & & 36 & & & \\
\hline & $92 *$ & & & & & 72 & 7 \\
\hline
\end{tabular}




\section{Figures}

1. Merged onshore-offshore (topographic-bathymetric) surface model for the northern UK and surrounding continental shelf (after Bradwell et al., 2008). Offshore data from Olex AS; onshore data from NEXTMap Britain digital surface model (Intermap Technologies). Boxes show areas covered by Figure 3 and 4.

2. Summary of Late Quaternary chronostratigraphic stages (Great Britain) and their correlation with Marine Isotope Stages. The approximate timing of the local LGM (c. 30-25 ka) (Bradwell et al., 2008) and global LGM (23-21 ka) (Hughes et al., 2016) is shown.

3. Transport paths of some indicator erratics in NE Scotland (after Read, 1923; Bremner, 1928; Synge, 1956; Sissons, 1967; Merritt et al., 2003). NEXTMap Britain digital surface model (Intermap Technologies).

4. Transport paths of some indicator erratics across the inner Moray Firth (after Mackie, 1905; Sissons, 1967; Fletcher et al., 1996). NEXTMap Britain digital surface model (Intermap Technologies).

5. Generalised flow-lines of ice and conceptual profile map of the five subgroups of glacigenic deposits present in NE Scotland (after Merritt et al., 2003). Area of minor glacial erosion after Synge (1956). NEXTMap Britain digital surface model (Intermap Technologies).

6. Reconstruction of ice-free enclaves and proglacial lakes in Buchan: (a) confluence between ice lobes during stage 5, creation of $80 \mathrm{~m}$ Glacial Lake Ugie (GLU) followed by the 'Logie-Buchan Readvance' and creation of $50 \mathrm{~m}$ GLU during stage 6; (b) decay of the Logie-Buchan ice lobe, further retreat of East Grampian ice followed by re-advance of Moray Firth ice during stages 79; (c) St. Fergus Readvance and subsequent ponding along the Banffshire coast during stages 10-11.

7. Flowsets of the last BIIS in north-eastern Scotland (modified after Hughes et al., 2014, fig. 3). NEXTMap Britain digital surface model (Intermap Technologies).

8. Reconstruction of the retreat pattern of the last BIIS across north-eastern Scotland (modified after Clark et al., 2012, fig 12). Limits off the north coast of Caithness and Sutherland taken from Bradwell and Stoker (2015b). Boxes A and $B$ show hill-shaded digital surface models of two areas lying to the south of the Moray Firth. Boxes C-E show linear seabed features interpreted as possible de Geer moraines (after Bradwell et al., 2008). Merged onshoreoffshore (topographic-bathymetric) surface model with offshore data from Olex AS; onshore data from NEXTMap Britain digital surface model (Intermap Technologies).

9. Conceptual glacial reconstructions depicting stages in the evolution of the north-eastern quadrant of the last BIIS: (1) Reconstruction of Boulton et al. 
(1985, fig. 10); (2) Local LGM (stage 2); (3) Considerable thinning and glacial reorganisation during stages 3 and 4; (4) Re-expansion following initial marine ingression into WGB during stage 5, followed by probable coalescence of BIIS and the Norwegian Channel Ice Stream at the Tampen Ridge (see cartoon 6 for limits); (5) Marine ingression to Lunan Bay during Stage 7; (6) Stages 8-12 and other limits after Clark et al. (2012, fig.12 and 13). Red hexagons show the centre of the Witch Ground Basin. Ice divides shown by thick black lines with open diamonds; single filled ticks denote ice divide receding by ice stream headward scavenging.

\section{Tables}

1. Hierarchy and correlation of flowsets in NE Scotland; top after Hughes et al. (2014); bottom as suggested here with asterisks denoting change in deduced flow direction. Size of box denotes uncertainty in age or time-transgressive nature of flowset.

2. Main stratigraphically important sites (numbered localities are described in Merritt et al., 2003, Appendix A).

3. Correlation of lithostratigraphical units in NE Scotland (modified after Merritt et al., 2003).

4. Lithology, matrix palynology and interpreted ice flow directions derived from clast fabrics (and associated striae) for Middle-Late Devensian till units in NE Scotland. From published and unpublished sources. 
Table 1. Hierarchy and correlation of flow-sets in NE Scotland; top after Hughes et al. (2014); bottom as suggested here with asterisks denoting change in deduced flow direction. Vertical axes denote relative age. Size of boxes denote uncertainty in age or timetransgressive nature of flowset.

\begin{tabular}{|l|l|l|l|l|l|l|l|l|}
\hline 6 & 47,96 & 92 & & 100 & & & 56 & \\
\cline { 1 - 2 } 3 & 34 & 35 & 36 & & 64 & & \\
\cline { 2 - 3 } & \multicolumn{3}{|c|}{33} & & & & 51 & \\
\cline { 1 - 2 } & & & & 93 & & 7 \\
\hline
\end{tabular}

\begin{tabular}{|l|l|l|l|l|l|l|l|}
\hline 6 & 47,96 & & & & & & \\
\hline 3 & 95, & & & & & & \\
\hline & 94 & & & 100 & & & 56 \\
\hline & & & $35 *$ & & 64,93 & & \\
\hline & & \multirow{2}{*}{33} & & & & & 51 \\
\hline & 34 & & 36 & & & \\
\hline & 34 & & & & & 72 & 7 \\
\hline
\end{tabular}


Table 2. Main stratigraphically important sites (numbered localities are described in Merritt et al., 2003, Appendix A)

\begin{tabular}{|c|c|c|c|c|c|c|}
\hline Site name & $\mathbf{n}$ & Location & Sheet & Grid Ref & Site characteristics and significance & Main original reference \\
\hline $\begin{array}{l}\text { Allt Odhar, } \\
\text { Moy }\end{array}$ & - & $\begin{array}{l}16 \mathrm{~km} \mathrm{SE} \text { of } \\
\text { Inverness }\end{array}$ & $84 \mathrm{~W}$ & NH 798368 & Early Devensian peat bed beneath till and overlying till. & Walker et al., 1992 \\
\hline Balnakettle & 24 & Fettercairn & $66 \mathrm{E}$ & NO 618757 & $\begin{array}{l}\text { Tectonised sequence of till and gelifractate revealing late readvance of } \\
\text { inland ice after retreat of Strathmore ice lobe. }\end{array}$ & Merritt et al., 2003 \\
\hline Baluss Bridge & 10 & $1 \mathrm{~km} \mathrm{~S}$ of Mintlaw & $87 \mathrm{~W}$ & NK 005473 & $\begin{array}{l}\text { Organic mud with Mesozoic palynomorphs associated with } 50 \mathrm{~m} \\
\text { Glacial Lake Ugie; late MIS } 2 \text { readvance of offshore ice lobes. }\end{array}$ & Hall and Connell, 1991 \\
\hline Boyne Quarry & 2 & $2.5 \mathrm{~km}$ E of Portsoy & $96 \mathrm{~W}$ & NJ 612658 & $\begin{array}{l}\text { Rafts of Mesozoic mudstone and shelly Pleistocene sediment, } \\
\text { glacitectonites, } 3 \text { tills, late-stage coastal ice-marginal lake deposits. }\end{array}$ & Peacock and Merritt, 2000 \\
\hline $\begin{array}{l}\text { Burn of } \\
\text { Benholm }\end{array}$ & 26 & $14 \mathrm{~km} \mathrm{~N}$ of Montrose & $57 \mathrm{E}$ & NO 795691 & $\begin{array}{l}\text { Strathmore till on rafted shelly diamict with clasts and microfossils } \\
\text { from North Sea basin; intervening bed of Early Devensian peat. }\end{array}$ & Auton et al., 2000 \\
\hline Camp Fauld & 14 & Moss of Cruden & $87 \mathrm{E}$ & NK 049410 & Two tills separated by Early Devensian peat beds & Whittington et al., 1993 \\
\hline Castle Hill & 3 & Gardenstown & $96 \mathrm{E}$ & NJ 795642 & $\begin{array}{l}\text { Rafts of Mesozoic strata and shelly Pleistocene sediment capped by till, } \\
\text { glacitectonites, late-stage coastal ice-marginal lake deposits. }\end{array}$ & Peacock and Merritt, 1997 \\
\hline Clava & - & $9 \mathrm{~km} \mathrm{E}$ of Inverness & $84 \mathrm{~W}$ & NH 766442 & Rafts of MIS 3? shelly clay and gravel within sequence of tills. & Merritt, 1992 \\
\hline Crossbrae Farm & 5 & $3 \mathrm{~km} \mathrm{NE}$ of Turriff & $86 \mathrm{E}$ & NJ 753512 & Early Devensian peat bed beneath gravel and diamict. & Whittington et al., 1998 \\
\hline Cross-Stone & - & $3 \mathrm{~km} \mathrm{~S}$ of Ellon & $87 \mathrm{~W}$ & NJ 954278 & $\begin{array}{l}\text { End-moraines of Logie-Buchan ice lobe, multiple tills, sands and } \\
\text { gravels indicating complex interaction of inland and coastal ice. }\end{array}$ & Gemmell et al., 2007 \\
\hline Dalcharn & - & $6 \mathrm{~km} \mathrm{SW}$ of Cawdor & $84 \mathrm{~W}$ & NH 815452 & Ipswichian palaeosol with till below and 3 till units above. & Walker et al., 1992 \\
\hline $\begin{array}{l}\text { Ellon; } \\
\text { Bellscamphie }\end{array}$ & 15 & Area NE of Ellon & $87 \mathrm{E}$ & NK 018337 & $\begin{array}{l}\text { Interbedded tills and gravel of contrasting provenance, including shelly } \\
\text { 'indigo' till. }\end{array}$ & Hall and Jarvis, 1995 \\
\hline Errollston & 17 & Cruden Bay & $87 \mathrm{E}$ & NK 088368 & $\begin{array}{l}\text { Red lacustrine clay and diamict with clasts from the North Sea basin } \\
\text { and inclusions of organic mud with Mesozoic palynomorphs. }\end{array}$ & Peacock, 1984 \\
\hline Howe of Byth & 6 & $17 \mathrm{~km}$ ESE of Banff & 97 & NJ 839753 & MIS 3? ice-proximal fan capped by till and younger outwash fan. & Hall et al., 1995 \\
\hline King Edward & 4 & $6 \mathrm{~km} \mathrm{~N}$ of Turriff & $86 \mathrm{E}$ & NJ 722561 & Rafted MIS3/4 shelly deposits and diamict. & Sutherland, 1981, 1984b \\
\hline Kippet Hills & 16 & Slains, Logie-Buchan & $87 \mathrm{E}$ & NK 030315 & $\begin{array}{l}\text { Esker and fan gravel with early Pleistocene shells and Permo-Triassic } \\
\text { to Tertiary lithologies from offshore in the North Sea basin. }\end{array}$ & Gordon, 1993b \\
\hline $\begin{array}{l}\text { Kirkhill and } \\
\text { Leys quarries }\end{array}$ & 7 & $\begin{array}{l}13 \mathrm{~km} \mathrm{NW} \text { of } \\
\text { Peterhead }\end{array}$ & $87 \mathrm{~W}$ & $\begin{array}{l}\text { NK } 011528 \\
\text { NK } 005525\end{array}$ & $\begin{array}{l}\text { Unique sequence of glacial, glaciofluvial, periglacial, pedogenic and } \\
\text { fluvial units spanning three } 100 \mathrm{ka} \text { glacial cycles. }\end{array}$ & $\begin{array}{l}\text { Connell et al., } 1982 \\
\text { Hall and Connell, 1991; } \\
\text { Hall and Jarvis, 1993a }\end{array}$ \\
\hline Mill of Dyce & 18 & Lower Don valley & 77 & NJ 871152 & Deltaic deposits formed during 'unzipping' of inland and offshore ice. & Aitken, 1995 \\
\hline Nigg Bay & 22 & $\begin{array}{l}\text { Lower Dee valley, } \\
\text { Aberdeen }\end{array}$ & 77 & NJ 965045 & $\begin{array}{l}\text { Interbedded tills and gravel of inland and Strathmore provenance. Type } \\
\text { site of the 'Aberdeen Readvance'. Lowest exposed sands and gravels } \\
\text { of MIS } 4 \text { ? date }\end{array}$ & $\begin{array}{l}\text { Gordon, 1993c, Merritt et } \\
\text { al., } 2003\end{array}$ \\
\hline
\end{tabular}




\begin{tabular}{|c|c|c|c|c|c|c|}
\hline $\begin{array}{l}\text { Kingswells, } \\
\text { Aberdeen }\end{array}$ & 22 & $6 \mathrm{~km} \mathrm{~W}$ of Aberdeen & 77 & NJ 879061 & $\begin{array}{l}\text { Till deposited by ice flowing SE overlain by till deposited by ice } \\
\text { flowing ESE. Similar sequence observed by earlier works in gas pipe } \\
\text { line trenches to the N. }\end{array}$ & Merritt et al., 2003 \\
\hline Oldmill & 8 & $\begin{array}{l}10 \mathrm{~km} \text { WSW of } \\
\text { Peterhead }\end{array}$ & $87 \mathrm{E}$ & NK 024439 & $\begin{array}{l}\text { Rafts of Mesozoic mudstone and Pleistocene glaciomarine mud, } \\
\text { glacitectonites, capped by tills, MIS4? Deltaic gravel at base. }\end{array}$ & Hall, 1984a \\
\hline Sandford Bay & 12 & $3 \mathrm{~km} \mathrm{~S}$ of Peterhead & $87 \mathrm{E}$ & NK 125434 & $\begin{array}{l}\text { Inland till overlain by clays deposited in Glacial Lake Ugie, capped by } \\
\text { red shelly diamict deposited by ice flowing onshore from SE. }\end{array}$ & Hall and Connell, 1991 \\
\hline St.Fergus & 11 & $\begin{array}{l}6 \mathrm{~km} \mathrm{WNW} \text { of } \\
\text { Peterhead }\end{array}$ & $87 \mathrm{E}$ & NK 124434 & $\begin{array}{l}12 \mathrm{~m} \text { OD late-glacial raised beach and glaciomarine silts disturbed by } \\
\text { ice pushing from E/NE during the St Fergus Readvance. }\end{array}$ & $\begin{array}{l}\text { Hall and Jarvis, 1989; } \\
\text { Peacock, } 1997 .\end{array}$ \\
\hline Strabathie & 19 & $8 \mathrm{~km} \mathrm{~N}$ of Aberdeen & 77 & NJ 958135 & $\begin{array}{l}\text { Deltaic and glaciolacustrine sequence formed during parting of inland } \\
\text { and offshore ice lobes. }\end{array}$ & $\begin{array}{l}\text { Thomas and Connell, } \\
\text { 1985; Aitken, } 1993\end{array}$ \\
\hline Teindland & 1 & Lower Strath Spey & $85 \mathrm{E}$ & NJ 297570 & Multiple tills, 4 of which overlie a MIS5e palaeosol. & Hall et al., 1995a \\
\hline Tillybrex & 15 & $6 \mathrm{~km}$ NE Ellon & $87 \mathrm{~W}$ & NK 001347 & Interbedded tills and gravel of contrasting provenance and age. & Hall and Jarvis, 1995 \\
\hline Toddlehills & - & $\begin{array}{l}6 \mathrm{~km} \mathrm{WSW} \text { of } \\
\text { Peterhead }\end{array}$ & $87 \mathrm{E}$ & NK 069453 & $\begin{array}{l}\text { Devensian and pre-Devensian tills separated by Early Devensian? } \\
\text { fluvial sands }\end{array}$ & Gemmell et al., 2007 \\
\hline
\end{tabular}




\begin{tabular}{|c|c|c|c|c|c|c|c|c|c|c|c|}
\hline & & olour key to C & acigenic Subgroups ; & Inverness (IGS); Centr & al Grampian (CGGS) & ; East Grampian (EGGS & ) ; Banffshire Coast an & Caithness (BCCGS) ; Log & gie-Buchan (L-BGS) & ; Mearns (MGS). & \\
\hline Stage & Flowset & NAIRN & TEINDLAND/ELGIN & BOYNE Q / KEITH & BANFF & BYTH / CROSSBRAE & KIRKHILL / LEYS & PETERHEAD / CRUDEN & ELLON & ABERDEEN & STRATHMORE \\
\hline & & & Spynie Clay & & & & & & & & \\
\hline 12 & Elgin Oscillation & Finglack Till & Waterworks Till & & & & & & & & \\
\hline 11 & 47 & Finglack Till & laminated clays of & Arnhash Till & & & & & & & \\
\hline 11 & 94,95 & Finglack Till & Glacial Lake Rothes & Blackhills S\&G & Blackhills S\&G & & & & & & \\
\hline 11 & 35 & Finglack Till & & 'Northern Drift" & Kirk Burn Silt & & & & & & \\
\hline 10 & St Fergus Rdv & Finglack Till & & Blairdaff Moraine & & & & St Fergus Moraine & & & \\
\hline 10 & & Finglack Till & & & & & & St.Fergus Silt & & & \\
\hline 9 & 100 & Finglack Till & & & & & & Essie Till F & & & \\
\hline$? 8$ & & & & & & Crossbrae Gelifluct & Manse Gelifluct & & & & \\
\hline 7 & & & & & & & & & Tullos Clay & Tullos Clay & Lunan Bay Clay \\
\hline 7 & 56 & & & & & & & & & & Drumlithie S\&G \\
\hline 6 & & Ruallan Till & & & & & & 50m Lake Ugie deltas & & 'Balnagask Till" & Mill of Forest Till \\
\hline 6 & & Ruallan Till & & & & & & & Kippet Hills S \& G & Drumlithie S\&G & Mill of Forest Till \\
\hline 6 & 64 & Ruallan Till & & & & & & Ugie Silt & L-BGS undif & Mill of Forest Till & Mill of Forest Till \\
\hline 5 & & Ruallan Till & & & & Auchmeddon Gr & Kirkhill Church Sand & 80m Lake Ugie deltas & L-BGS undif & Lochton S\&G & Mill of Forest Till \\
\hline 5 & 51,33 & Ruallan Till & & & & & & Hatton Till & Hatton Till & Banchory Till & Mill of Forest Till \\
\hline 4 & 34 & Cantray Till & Tofthead Till & Old Hythe Till & Crovie Till & Byth Till & & & & Den Burn Till & \\
\hline 3 & 36 & & & & & & Hythie Till & Sandford Bay Till & Bearnie Till & ?Ness S \& G & \\
\hline 2 & $7,72 ?$ & Athais Till & Altonside Till & Whitehills Glaci F & Whitehills Glaci F & cryoturbate & Corse Diamict & Whitehills Glaci F & Pitlurg Till & Anderson Drive Dm & \\
\hline 1 & $92 ?$ & Athais Till & Woodside Diamict & & & Howe of Byth Gr & & & & & \\
\hline MIS 3 & & Athais Till & & & & & Corsend Gelifluct & & & & \\
\hline & & & & & Pushlinn Burn Gr & & & Aldie Till & & & \\
\hline MIS 4 & & & Badentinian Sand (MIS & $4-5 a)$ & & & & Hardslacks Gelifluct & & ?Ness S \& G & \\
\hline MIS 5a-c & & Moy Burn Pal & & & & Crossbrae F Peat & & Berryley Peat & & & Benholm Peat \\
\hline MIS 5e & & Dalcharn Pal & Teindland Pal & Truncated palaeosol & & & Fernieslack Pal & & & & \\
\hline & & & Deanshillock Gravel & & & & & Moreseat F Sand & & & \\
\hline MIS 6? & & Cassie Till & Red Burn Till & Craig of Boyne Till & & Crossbrae Till & Rottenhill Till & Camp Fauld Till & Bellscamphie Till & & Benholm Clay \\
\hline$>$ MIS 6 & & & & & & & West Leys S \& G & & Tillybrex S\&G & & Birnie Gravel \\
\hline Note: The firs & st column refers to $b$ & both Marine Isoto & Stages (MIS) and the 12 & stage event stratigraph & y of the paper. & & & & & & \\
\hline Flowsets afte & er Hughes et al. (201 & 14), but some str & dile more than one stage & Table 1). Dated units o & f the Britannia Catchn & hents Group in bold black. & & & & & \\
\hline ome units ( & eg Auchmeddon $\mathrm{C}$ & avel, Crossbrae & 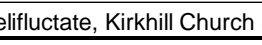 & sand and ivatise Gemi & crale) are depr & 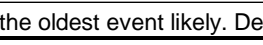 & & & cied & & \\
\hline
\end{tabular}


Table 4. Lithology, matrix palynology and interpreted ice flow directions derived from clast fabrics (and associated striae) for Middle-Late Devensian till units in NE Scotland. From published and unpublished sources.

\begin{tabular}{|c|c|c|}
\hline Glacigenic subgroup & Formation, member & Till lithology and interpreted ice flow direction \\
\hline Mearns (MGS) & Mill of Forest Till F & $\begin{array}{l}\text { Typically very weakly calcareous, reddish brown } \\
\text { (5YR 4/4), sandy silty clay matrix. Dominated by } \\
\text { ORS conglomerate clasts and other Devonian } \\
\text { lithologies together with a range of igneous and } \\
\text { metamorphic types. Where sampled (Nigg Bay, } \\
\text { Aberdeen) matrix palynology reveals sparse } \\
\text { assemblages with Carboniferous, Permian and } \\
\text { Jurassic forms present. Ice flow toward NE and N. }\end{array}$ \\
\hline $\begin{array}{l}\text { Logie-Buchan } \\
\text { (L-BGS) }\end{array}$ & Hatton Till F & $\begin{array}{l}\text { Typically moderately calcareous, reddish brown } \\
\text { (5YR 4/4) to red (2.5YR 4/6) sandy clayey silt } \\
\text { matrix. Clast assemblages include ORS lithologies, } \\
\text { Permian limestones, Mesozoic sediments, flint and } \\
\text { shell fragments. Matrix palynology comprises rich } \\
\text { assemblages of Jurassic dinocysts and miospores, } \\
\text { less quantities of Permian pollen and rare } \\
\text { Carboniferous, Cretaceous?, Palaeogene and } \\
\text { Quaternary forms. Ice flow to N and NNW. }\end{array}$ \\
\hline \multirow[t]{3}{*}{$\begin{array}{l}\text { East Grampian } \\
\text { (EGGS) }\end{array}$} & $\begin{array}{l}\text { Banchory Till F } \\
\text { Nigg Till M } \\
\text { Kingswells Till M } \\
\text { Den Burn Till M }\end{array}$ & $\begin{array}{l}\text { These tills typically have non calcareous, brown- } \\
\text { dark brown (10YR 4/3) to very dark greyish brown } \\
(2.5 Y R 3 / 2) \text { sandy silty clay matrices. Clast } \\
\text { assemblages are dominated by locally derived } \\
\text { igneous and metamorphic lithologies. Matrix } \\
\text { palynology of the Nigg Bay Till at Nigg Bay } \\
\text { revealed a moderately rich assemblage containing } \\
\text { some Carboniferous spores, a diverse assemblage } \\
\text { of Jurassic forms and Quaternary elements. The } \\
\text { assemblage probably has been locally reworked } \\
\text { from the Anderson Drive Till (see below). Ice flow } \\
\text { in the Nigg and Kingswells Tills towards the E and } \\
\text { ENE. The Denburn Till records flow towards ESE } \\
\text { and SE. }\end{array}$ \\
\hline & $\begin{array}{l}\text { Hythie Till F } \\
\text { Sandford Bay Till M } \\
\text { Bearnie Till M } \\
\text { Aldie Till M } \\
\text { Bellscamphie Till M }\end{array}$ & $\begin{array}{l}\text { These tills typically have non calcareous, strong } \\
\text { brown ( } 7.5 Y R 5 / 4) \text {, brown/dark brown (10YR } 4 / 3 \text { - } \\
3 / 3 \text { ), dark yellowish brown (10YR 4/4), and locally } \\
\text { greenish grey ( } 5 \mathrm{GY} 6 / 1) \text {, sandy silty clay matrices. } \\
\text { Clast assemblages in these deposits are dominated } \\
\text { by locally derived acid and basic igneous rocks and } \\
\text { metamorphic clasts. Locally well rounded flint and } \\
\text { metaquartzite clasts are derived from the Buchan } \\
\text { Gravels. Matrix palynology has investigated only } \\
\text { for the Bellscamphie Till, which contains a rich } \\
\text { assemblage of Early Carboniferous spores. Ice flow } \\
\text { towards ESE, E and ENE. }\end{array}$ \\
\hline & Byth Till F & $\begin{array}{l}\text { Non calcareous, reddish brown (5YR 4/3) sandy } \\
\text { silty clay matrix with clast assemblage dominated }\end{array}$ \\
\hline
\end{tabular}




\begin{tabular}{|c|c|c|}
\hline & & $\begin{array}{l}\text { by metaquartzite, psammite and ORS lithologies. } \\
\text { Ice flow to E and ESE. }\end{array}$ \\
\hline & Crovie Till F & $\begin{array}{l}\text { Reddish brown sandy clay matrix with clasts of } \\
\text { Dalradian metasediment and ORS conglomerate. } \\
\text { Ice flow towards ESE and SE. }\end{array}$ \\
\hline \multirow[t]{4}{*}{$\begin{array}{l}\text { Banffshire Coast and } \\
\text { Caithness (BCCGS) }\end{array}$} & $\begin{array}{l}\text { Whitehills Glacigenic } \\
\text { F } \\
\text { Corse Diamicton F } \\
\text { Pitlurg Till F } \\
\text { Anderson Drive Till F }\end{array}$ & $\begin{array}{l}\text { These units typically have non to very weakly } \\
\text { calcareous, very dark grey (10YR } 3 / 1) \text { to dark grey } \\
\text { ( } 5 \text { Y } 4 / 1 \text { ) and locally very dark grey ( } 2.5 Y R N / 3) \text { to } \\
\text { dark olive grey ( } 5 Y 3 / 1 \text { ) sandy clay silt matrices. } \\
\text { Clasts are typically dark mafic igneous and } \\
\text { metamorphic rock types with subsidiary ORS or } \\
\text { Triassic sandstones, Mesozoic sandstone? and } \\
\text { shell fragments. Matrix palynology assemblage are } \\
\text { dominated by Jurassic miospores and } \\
\text { microplankton. Ice flow towards } S \text { and SE. }\end{array}$ \\
\hline & Altonside Till F & $\begin{array}{l}\text { Similar lithology to the above and ice flow towards } \\
\text { the SE. }\end{array}$ \\
\hline & Essie Till F & $\begin{array}{l}\text { Moderately calcareous, very dark greyish brown } \\
\text { (10YR } 3 / 2) \text { to very dark greyish brown }(2.5 Y 3 / 2) \\
\text { and very dark grey }(5 Y 3 / 1) \text { clayey silt matrix. } \\
\text { Clasts are typically few, but include igneous and } \\
\text { metamorphic lithologies, chalk, Mesozoic? } \\
\text { sandstone and shell fragments. Reconnaissance } \\
\text { level palynology indicates a significant Jurassic } \\
\text { component to the assemblages with a probably } \\
\text { higher contribution from Cretaceous rocks. Flow } \\
\text { towards the SE, ESE and S. }\end{array}$ \\
\hline & Arnhash Till M & $\begin{array}{l}\text { Typically reddish brown sandy textured matrices } \\
\text { with clasts derived principally from Devonian } \\
\text { sediments with subsidiary igneous and } \\
\text { metamorphic lithologies. Ice flow towards the SE } \\
\text { and S. }\end{array}$ \\
\hline $\begin{array}{l}\text { Central Grampian } \\
\text { (CGGS) }\end{array}$ & $\begin{array}{l}\text { Waterworks Till F } \\
\text { Ruallan Till F } \\
\text { Tofthead Till F } \\
\text { Cantray Till F } \\
\text { Woodside Diamicton } \\
\text { F }\end{array}$ & $\begin{array}{l}\text { These tills typically have reddish brown, sandy silty } \\
\text { clay matrices. Clast assemblages are dominated by } \\
\text { metaquartzites and psammites with subsidiary } \\
\text { acid and basic igneous rocks, some ORS lithologies } \\
\text { and Mesozoic rocks. Ice flow towards the ESE and } \\
\text { SE. }\end{array}$ \\
\hline
\end{tabular}




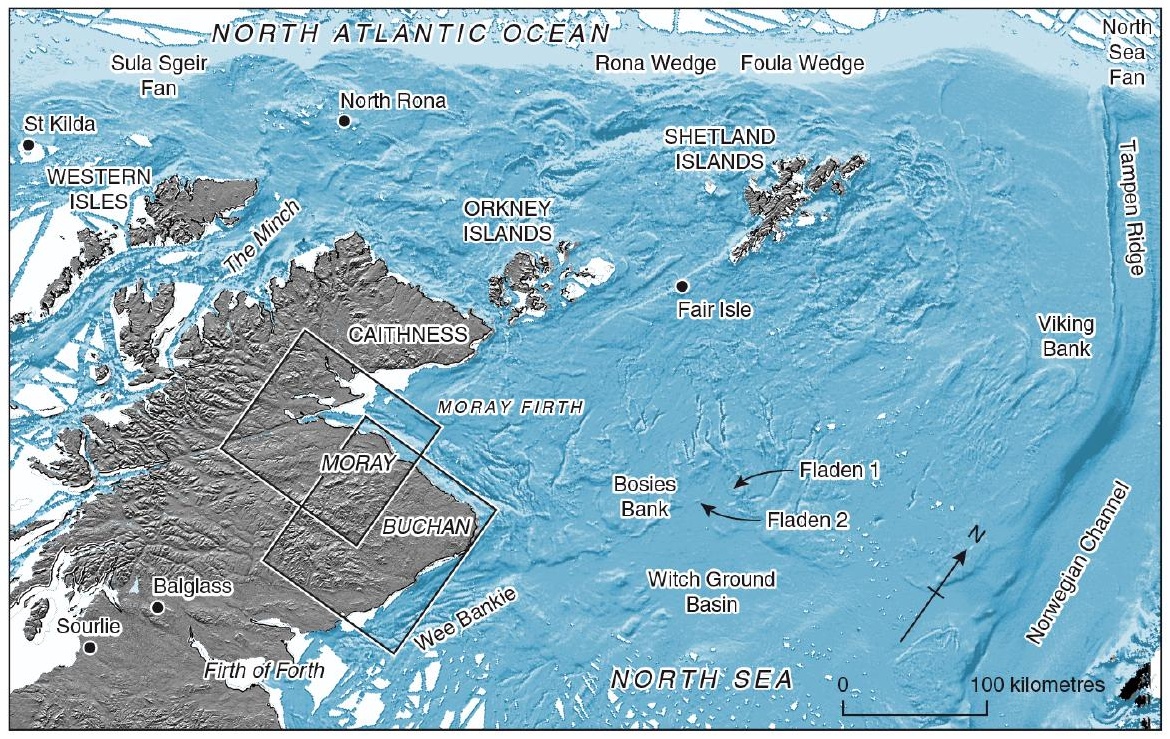




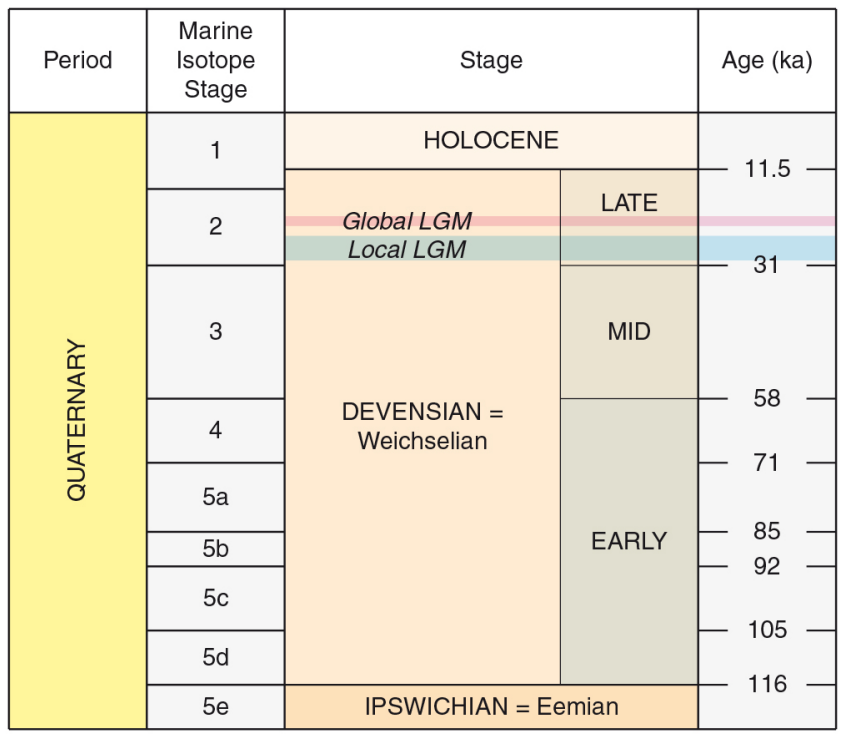




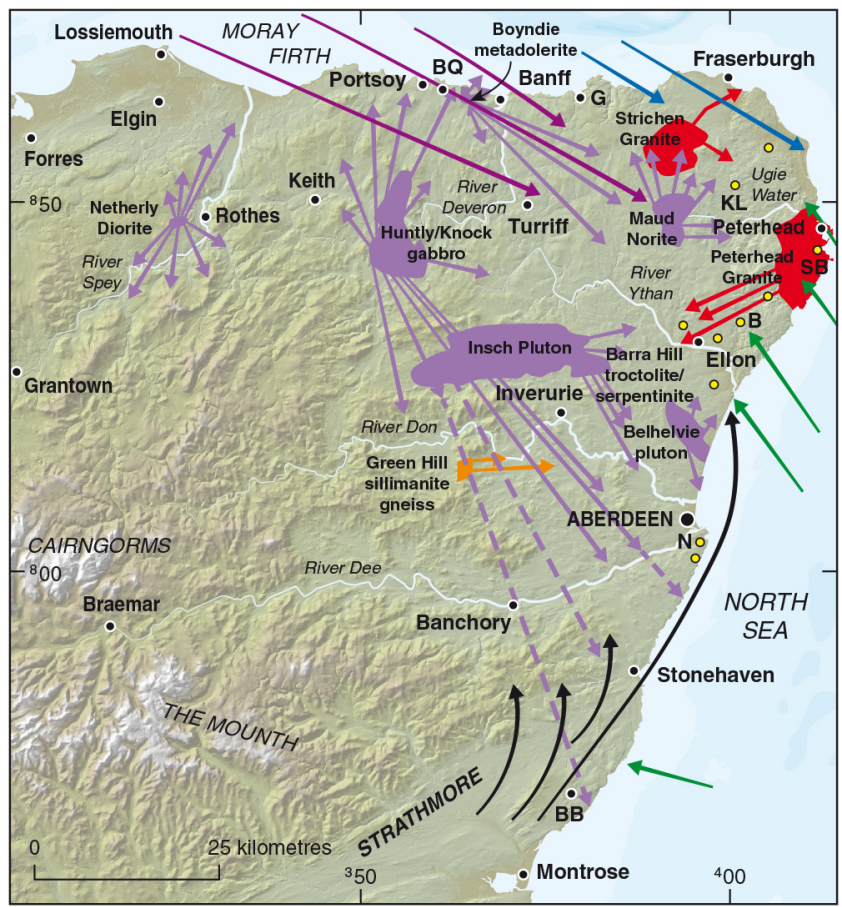




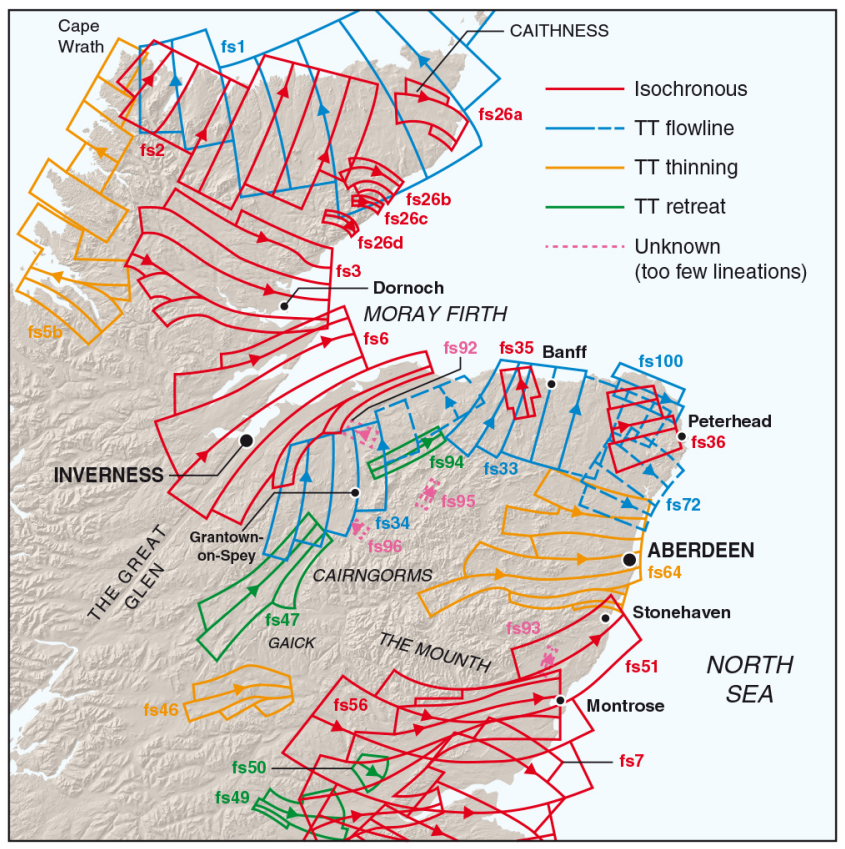




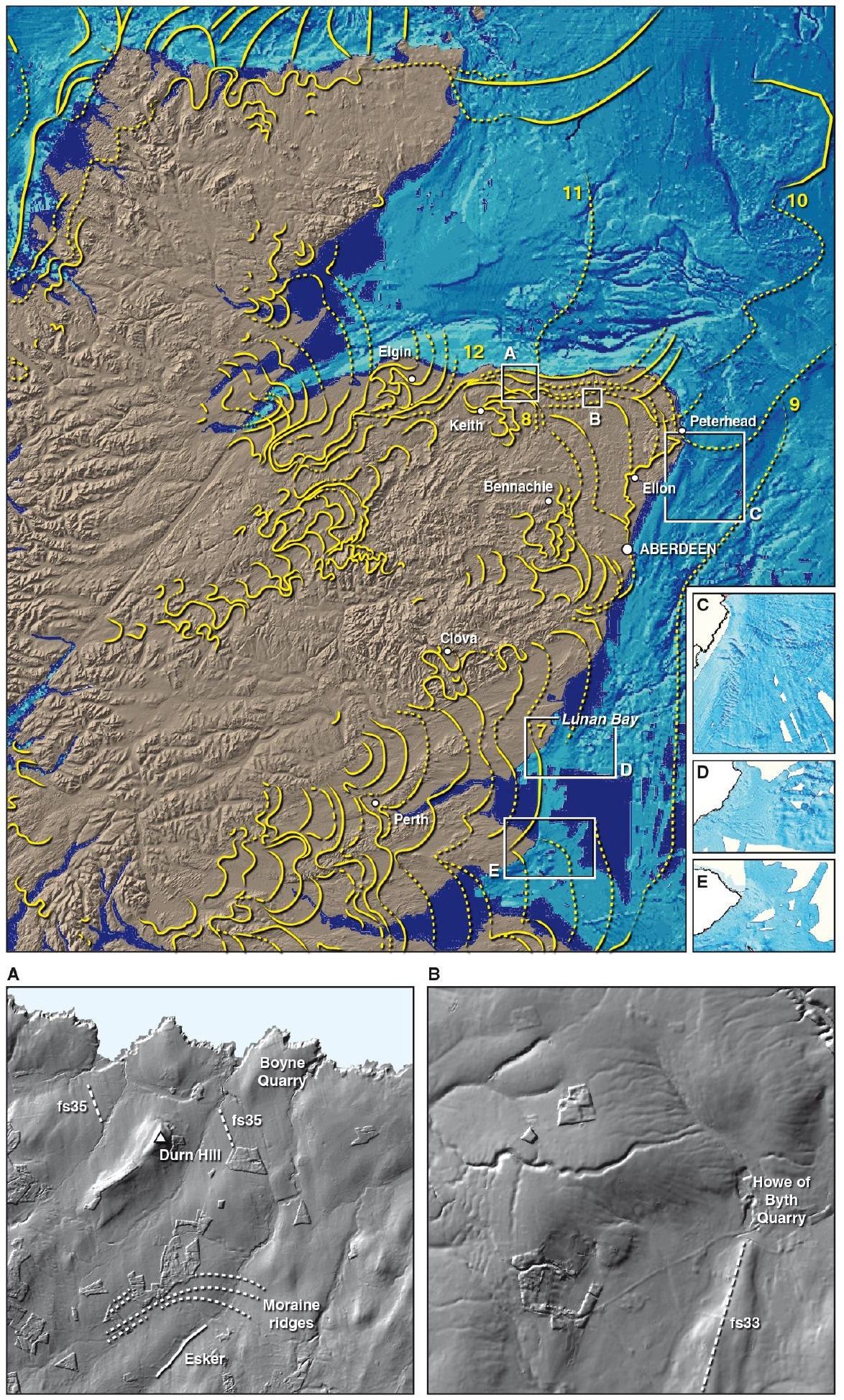



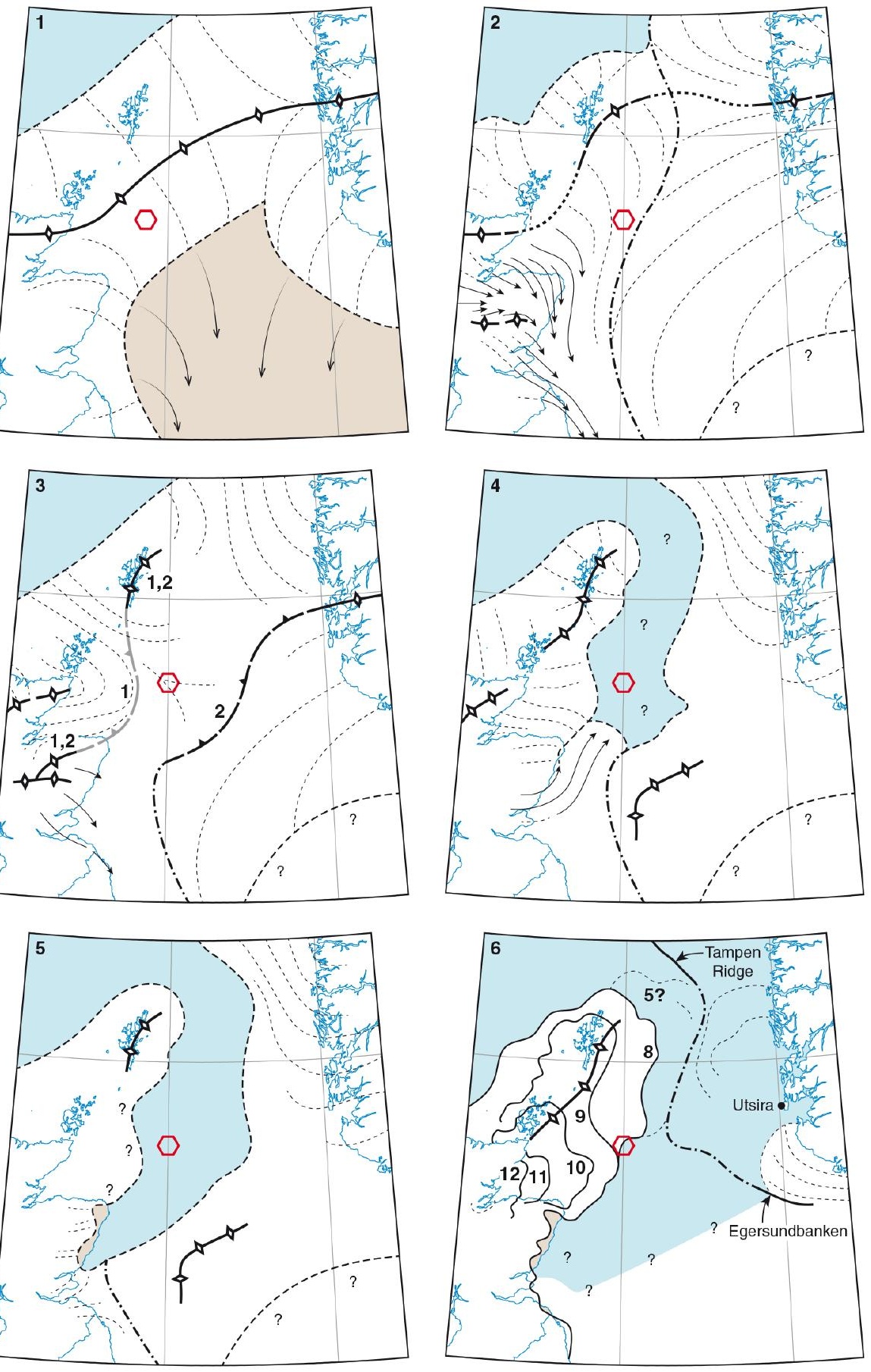